AroO national laboratory

ANL-10/24

\title{
Technical Assessment of Compressed Hydrogen Storage Tank Systems for Automotive Applications
}

Nuclear Engineering Division 


\begin{abstract}
About Argonne National Laboratory
Argonne is a U.S. Department of Energy laboratory managed by UChicago Argonne, LLC under contract DE-AC02-06CH11357. The Laboratory's main facility is outside Chicago, at 9700 South Cass Avenue, Argonne, Illinois 60439. For information about Argonne and its pioneering science and technology programs, see www.anl.gov.
\end{abstract}

\title{
Availability of This Report
}

This report is available, at no cost, at http://www.osti.gov/bridge. It is also available on paper to the U.S. Department of Energy and its contractors, for a processing fee, from:

U.S. Department of Energy

Office of Scientific and Technical Information

P.O. Box 62

Oak Ridge, TN 37831-0062

phone (865) 576-8401

fax (865) 576-5728

reports@adonis.osti.gov

\begin{abstract}
Disclaimer
This report was prepared as an account of work sponsored by an agency of the United States Government. Neither the United States Government nor any agency thereof, nor UChicago Argonne, LLC, nor any of their employees or officers, makes any warranty, express or implied, or assumes any legal liability or responsibility for the accuracy, completeness, or usefulness of any information, apparatus, product, or process disclosed, or represents that its use would not infringe privately owned rights. Reference herein to any specific commercial product, process, or service by trade name, trademark, manufacturer, or otherwise, does not necessarily constitute or imply its endorsement, recommendation, or favoring by the United States Government or any agency thereof. The views and opinions of document authors expressed herein do not necessarily state or reflect those of the United States Government or any agency thereof, Argonne National Laboratory, or UChicago Argonne, LLC.
\end{abstract}




\section{Technical Assessment of Compressed Hydrogen Storage Tank Systems for Automotive Applications}

prepared by

Thanh Hua ${ }^{1}$, Rajesh Ahluwalia ${ }^{1}$, J-K Peng ${ }^{1}$, Matt Kromer², Stephen Lasher², Kurtis McKenney², Karen Law², and Jayanti Sinha²

${ }^{1}$ Nuclear Engineering Division, Argonne National Laboratory, Argonne, Illinois

${ }^{2}$ TIAX LLC, Lexington, MA

September 2010 


\section{Table of Contents}

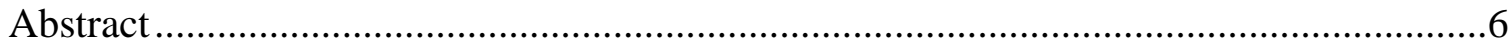

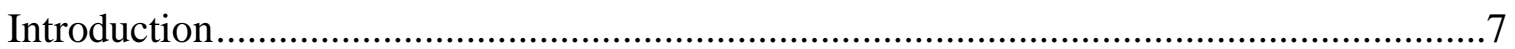

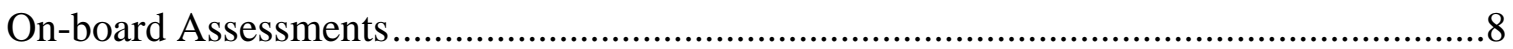

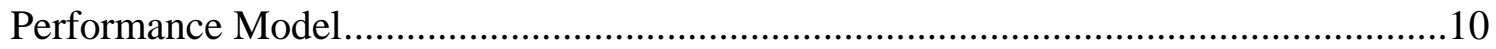

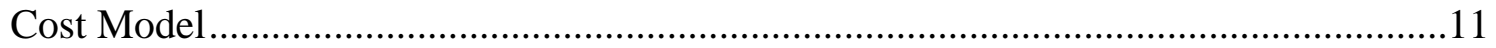

Performance Results for Type IV Single Tank Systems ..............................................14

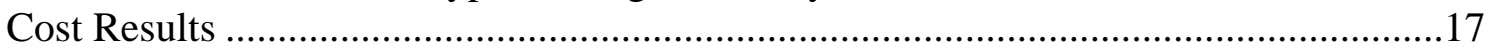

Assessments of Type-III vs. Type-IV Tanks ...........................................................19

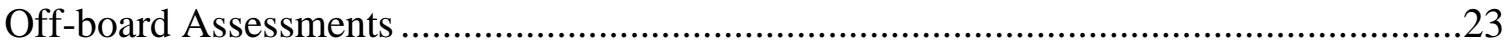

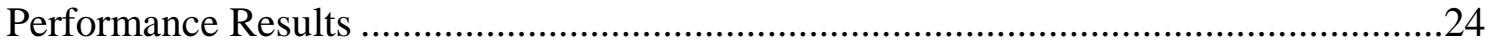

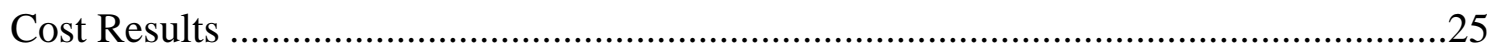

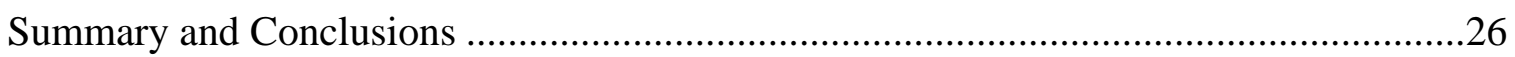

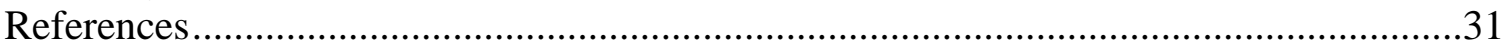

APPENDIX A: Performance Assessment of Compressed Hydrogen Storage Systems....32

APPENDIX B: Cost Assessment of Compressed Hydrogen Storage Systems 


\section{List of Figures}

Figure 1: On-board compressed hydrogen storage system schematic ........................................... 8

Figure 2: Base case weight and volume distributions for the compressed hydrogen storage

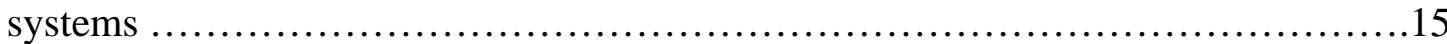

Figure 3: Gravimetric and volumetric capacities of compressed hydrogen storage systems and their sensitivity to tank empty pressure and carbon fiber translation efficiency ... 16

Figure 4: Base case component cost breakout for the compressed hydrogen storage system..... 17

Figure 5: On-board compressed hydrogen storage for dual tank system........................20

Figure 6: Comparison of capacities for Type-III and Type-IV tanks, single and dual tank 350-bar storage systems.........................................................21

Figure 7: Comparison of capacities for Type-III and Type-IV tanks, single and dual tank

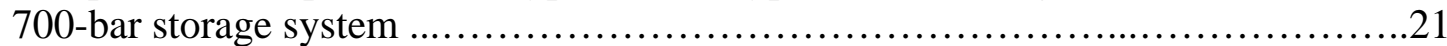

Figure 8: Comparison of system cost projections for Type-III and Type-IV tanks, single and dual tank systems, and 350-bar and 700-bar storage..............................22 


\section{List of Tables}

Table I: Summary results of the assessment for compressed hydrogen storage systems compared

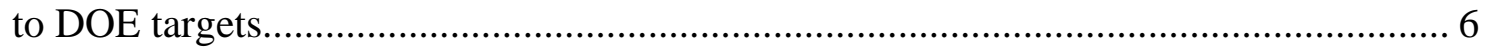

Table 1: On-board compressed hydrogen storage system design assumptions ............................. 9

Table 2: Base case material versus processing cost breakout for compressed hydrogen storage

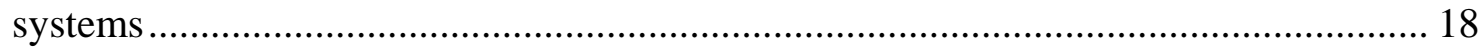

Table 3: Summary results of the on-board cost assessment for 350 and 700-bar compressed hydrogen storage systems compared to DOE cost targets ............................................. 18

Table 4: Life cycle assumptions for pipeline delivery scenario ............................................ 24

Table 5: Fuel system ownership cost assumptions and results .................................................... 26

Table 6: Summary results of the assessment for compressed hydrogen storage systems ............ 27

Table 7: Summary results of the assessment for Type-III and Type-IV single and dual tank

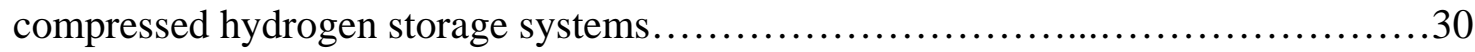




\section{Acknowledgement and Disclaimer}

This report was prepared as an account of work sponsored by an agency of the United States Government. Neither the United States Government nor any agency thereof, nor TIAX LLC, nor any of their employees, makes any warranty, express or implied, or assumes any legal liability or responsibility for the accuracy, completeness, or usefulness of any information, apparatus, product, or process disclosed, or represents that its use would not infringe privately owned rights. Reference herein to any specific commercial product, process, or service by trade name, trademark, manufacturer, or otherwise does not necessarily constitute or imply its endorsement, recommendation or favoring by the United States Government or any agency thereof. The views and opinions of authors expressed herein do not necessarily state or reflect those of the United States Government or any agency thereof.

This report, and the conclusions contained herein, are the result of the exercise of Argonne National Laboratory (Argonne, ANL) and TIAX's professional judgment, based in part upon materials and information provided to us by third parties, which in certain cases, have not been independently verified. Argonne and TIAX accept no duty of care or liability of any kind whatsoever to any third party, and no responsibility for damages, if any, suffered by any third party as a result of decisions made, or not made, or actions taken, or not taken, based on this document, or use of any of the information contained herein. This report may be produced only in its entirety.

The cost analysis for the compressed gas tank systems assumes Year 2009 technology status for individual components, and projects their cost at production volumes of 500,000 vehicles/year. It is not known whether the exact system configuration adopted for this cost analysis currently exists as an integrated automotive hydrogen storage system, or how well the components and subsystems inter-operate with each other. In developing the system configuration and component manifests, we have tried to capture all of the essential engineering components and important cost contributors. However, the system selected for costing does not claim to solve all of the technical challenges facing hydrogen storage transportation systems or satisfy DOE or FreedomCAR on-board hydrogen storage performance, safety, and durability targets. 


\title{
Technical Assessment of Compressed Hydrogen Storage Tank Systems for Automotive Applications
}

\author{
T. Q. Hua, R. K. Ahluwalia, and J-K Peng \\ Argonne National Laboratory, Argonne, IL 60439 \\ M. Kromer, S. Lasher, K. McKenney, K. Law, and J. Sinha \\ TIAX LLC, Lexington, MA 02421
}

\begin{abstract}
The performance and cost of compressed hydrogen storage tank systems has been assessed and compared to the U.S. Department of Energy (DOE) 2010, 2015, and ultimate targets for automotive applications. The on-board performance and high-volume manufacturing cost were determined for compressed hydrogen tanks with design pressures of 350 bar ( 5000 psi) and 700 bar ( 10,000 psi) capable of storing $5.6 \mathrm{~kg}$ of usable hydrogen. The off-board performance and cost of delivering compressed hydrogen was determined for hydrogen produced by central steam methane reforming (SMR). The main conclusions of the assessment are that the 350-bar compressed storage system has the potential to meet the 2010 and 2015 targets for system gravimetric capacity but will not likely meet any of the system targets for volumetric capacity or cost, given our base case assumptions. The 700-bar compressed storage system has the potential to meet only the 2010 target for system gravimetric capacity and is not likely to meet any of the system targets for volumetric capacity or cost, despite the fact that its volumetric capacity is much higher than that of the 350-bar system. Both the 350-bar and 700-bar systems come close to meeting the Well-to-Tank (WTT) efficiency target, but fall short by about 5\%. These results are summarized in Table I below.
\end{abstract}

Table I: Summary results of the assessment for compressed hydrogen storage systems compared to DOE targets

\begin{tabular}{|c|c|c|c|c|c|c|}
\hline $\begin{array}{c}\text { Performance and Cost } \\
\text { Metric }\end{array}$ & Units & 350-bar & 700-bar & $\begin{array}{l}2010 \\
\text { Targets }\end{array}$ & $\begin{array}{l}2015 \\
\text { Targets }\end{array}$ & $\begin{array}{l}\text { Ultimate } \\
\text { Targets }\end{array}$ \\
\hline $\begin{array}{l}\text { System Gravimetric } \\
\text { Capacity }\end{array}$ & wt $\%$ & 5.5 & 5.2 & 4.5 & 5.5 & 7.5 \\
\hline $\begin{array}{l}\text { System Volumetric } \\
\text { Capacity }\end{array}$ & $\mathrm{g}-\mathrm{H}_{2} / \mathrm{L}$ & 17.6 & 26.3 & 28 & 40 & 70 \\
\hline Storage System Cost & $\$ / k W h$ & 15.4 & 18.7 & 4 & 2 & TBD \\
\hline Fuel Cost & $\$ / g g e^{*}$ & 4.22 & 4.33 & $2-3$ & $2-3$ & $2-3$ \\
\hline WTT Efficiency (LHV**) & $\%$ & 56.5 & 54.2 & 60 & 60 & 60 \\
\hline
\end{tabular}

*gge: gallon gasoline equivalent

**Lower heating value 


\section{Introduction}

The DOE Hydrogen Program sponsored performance and cost assessments of compressed hydrogen storage for automotive applications during 2006-2009, consistent with the Program's Multiyear Research, Development and Demonstration Plan. This report summarizes the results of these assessments. The results should be considered only in conjunction with the assumptions used in selecting, evaluating, and costing the systems discussed below and in the Appendices.

Compressed hydrogen storage refers to storing hydrogen at high pressures, typically 350 and 700 bar ( 5,000 and 10,000 psi), in a pressure capable vessel. This assessment was based primarily on publicly available information and design schematics of Quantum's Type IV compressed hydrogen storage tanks, which they manufacture in low-volume production today. The assessment included an independent review of the tank design and technical performance by Argonne National Laboratory (Argonne, ANL) [Hua 2010], an independent cost assessment by TIAX LLC (TIAX) [Kromer 2010], and comments received from the FreedomCAR \& Fuel Partnership Hydrogen Storage Technical Team, Quantum, Toray, Structural Composites Inc. (SCI), and other tank developers/manufacturers. We analyzed the compressed hydrogen system for its potential to meet the DOE 2010, 2015, and ultimate hydrogen storage targets for fuel cell and other hydrogen-fueled vehicles. Presentations by Argonne and TIAX describing their analyses in detail are given in Appendices A and B, respectively.

The assessments established the baseline system performance and cost of typical 350- and 700-bar tanks suitable for automotive applications. Results include both “on-board” (i.e., hydrogen storage system required on the vehicle) and "off-board” (i.e., fuel cycle and infrastructure necessary to refuel the on-board storage system) metrics, including:

- On-board Assessments: Performance metrics include the on-board system weight and volume. Cost metrics include the on-board system high-volume (i.e., 500,000 units/year) manufactured cost.

- Off-board Assessments: Performance metrics include the off-board Well-to-Tank (WTT) energy efficiency and greenhouse gas (GHG) emissions. Cost metrics include the refueling costs and combined fuel system “ownership cost” on a \$/mile driven basis.

Results of the assessments are compared to DOE targets for the on-board fuel system gravimetric capacity, volumetric capacity, and system factory cost, as well as the off-board fueling infrastructure energy efficiency, GHG emissions, and refueling cost. Other DOE targets, including on-board system durability/operability, are expected to be met by compressed hydrogen storage systems, so they were not included in these assessments. A summary of the assessment methods and results follows. 


\section{On-board Assessments}

We evaluated compressed hydrogen system designs with nominal design pressures of 350 bar and 700 bar, suitable for high-volume manufacturing for automotive applications, in particular hydrogen fuel cell vehicles (FCV). The base case designs assume carbon fiber-resin (CF) composite-wrapped single tank systems, with a high density polyethylene (HDPE) liner (i.e., Type IV tanks) capable of storing $5.6 \mathrm{~kg}$ usable hydrogen. Additional analysis of dual tank systems and aluminum lined (i.e., Type III) tanks was also conducted. Significant balance-ofplant (BOP) components include a primary pressure regulator, solenoid control valves, fill tube/port, and pressure gauge/transducer. Additional design assumptions and details are presented in Table 1, and an overall system schematic is presented in Figure 1.

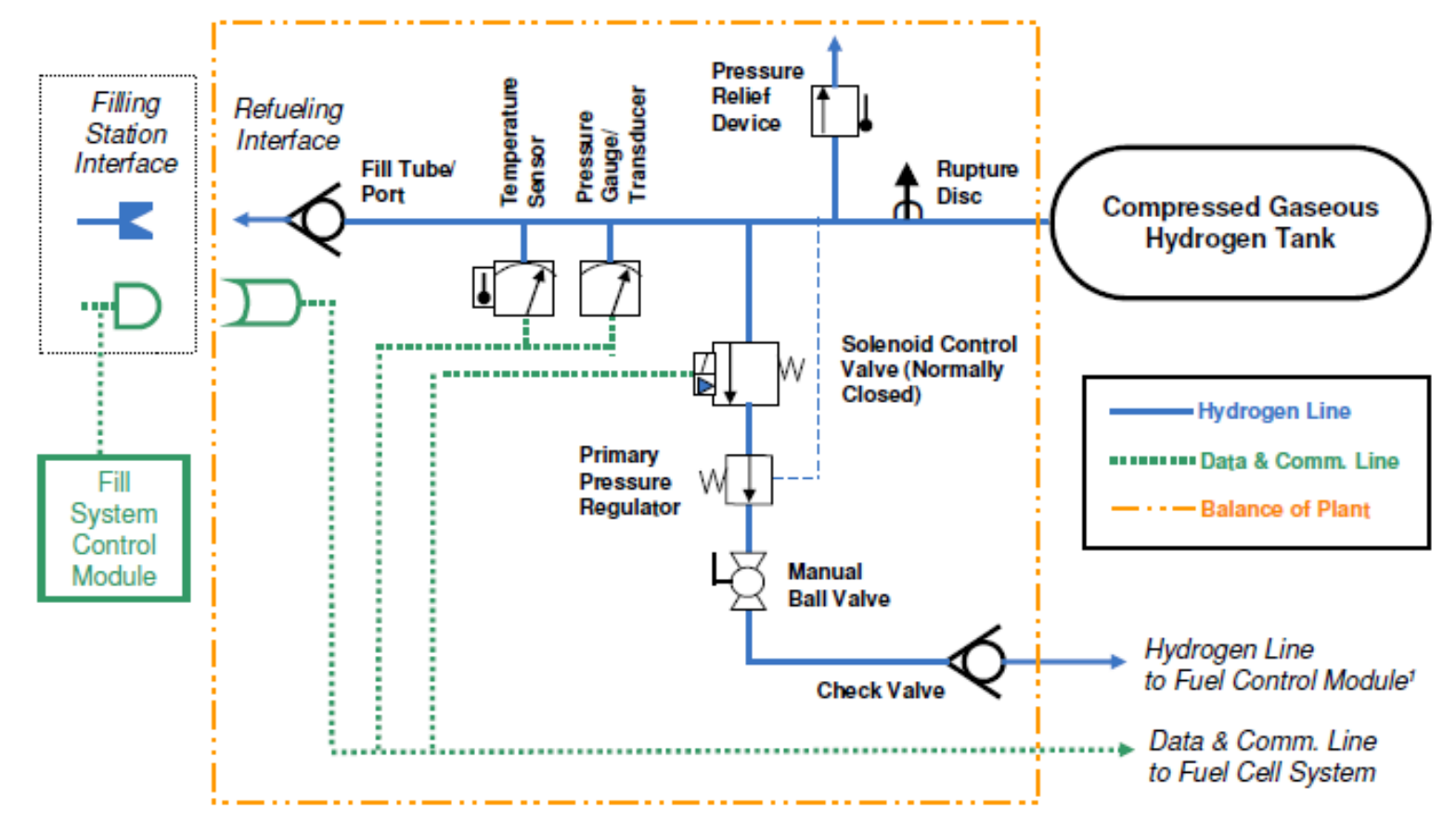

"Schematic based on the requirements defined in the draft European regulation "Hydrogen Vehicles: On-board Storage Systems" and US Patent 6,041,762.
1 Secondary Pressure Regulator located in Fuel Control Module of the Fuel Cell System.

Figure 1: On-board compressed hydrogen storage system schematic

The hydrogen storage system analysis assumes Year 2009 technology status for individual components, and projects their performance in a complete system, and their cost at production volumes of 500,000 vehicles/year. In developing the system configuration and component manifest, we tried to capture all of the essential engineering components and important performance and cost contributors. However, the system selected for this assessment does not necessarily solve all of the technical challenges facing hydrogen storage for transportation systems, nor fully satisfy DOE or FreedomCAR on-board hydrogen storage targets. 
Table 1: On-board compressed hydrogen storage system design assumptions

\begin{tabular}{|c|c|c|}
\hline Design Parameter & Base Case Value & Basis/Comment \\
\hline Nominal Pressure & 350 and 700 bar & $\begin{array}{l}\text { Design assumptions based on DOE and industry } \\
\text { input }\end{array}$ \\
\hline Number of Tanks & Single and Dual & $\begin{array}{l}\text { Design assumptions based on DOE and industry } \\
\text { input }\end{array}$ \\
\hline Tank Liner & $\begin{array}{l}\text { Aluminum (Type III) } \\
\text { HDPE (Type IV) }\end{array}$ & $\begin{array}{l}\text { Design assumptions based on DOE and industry } \\
\text { input }\end{array}$ \\
\hline $\begin{array}{l}\text { Maximum Filling } \\
\text { Pressure }\end{array}$ & $\begin{array}{l}\text { 350-bar: } 438 \text { bar } \\
\text { 700-bar: } 875 \text { bar }\end{array}$ & $\begin{array}{l}125 \% \text { nominal pressure is assumed required for } \\
\text { fast fills to prevent under-filling }\end{array}$ \\
\hline "Empty" Pressure & 20 bar & Discussions with Quantum, 2008 \\
\hline $\begin{array}{l}\text { Usable } \mathrm{H}_{2} \text { Storage } \\
\text { Capacity }\end{array}$ & $5.6 \mathrm{~kg}$ & $\begin{array}{l}\text { Design assumption based on drive-cycle modeling } \\
\text { for } 350 \text { mile range assuming a mid-sized, } \\
\text { hydrogen FCV [Ahluwalia } 2004 \text { and 2005] }\end{array}$ \\
\hline $\begin{array}{l}\text { Tank Size (water } \\
\text { capacity) }\end{array}$ & $\begin{array}{l}\text { 350-bar: } 258 \mathrm{~L} \\
\text { 700-bar: } 149 \mathrm{~L}\end{array}$ & $\begin{array}{l}\text { Calculated based on Benedict-Webb-Rubin } \\
\text { equation of state for } 5.6 \mathrm{~kg} \text { usable } \mathrm{H}_{2} \text { capacity and } \\
20 \text { bar "empty pressure" ( } 6.0 \text { and } 5.8 \mathrm{~kg} \text { total } \mathrm{H}_{2} \\
\text { capacity for } 350 \text {-bar and } 700 \text {-bar tanks, } \\
\text { respectively) }\end{array}$ \\
\hline Safety Factor & 2.25 & $\begin{array}{l}\text { Industry standard criteria (e.g., ISO/TS 15869) } \\
\text { applied to nominal storage pressure (i.e., } 350 \text { bar } \\
\text { and } 700 \text { bar) }\end{array}$ \\
\hline $\begin{array}{l}\text { Length/Diameter } \\
\text { Ratio }\end{array}$ & 3.0 & $\begin{array}{l}\text { Discussions with Quantum, 2008; based on the } \\
\text { outside of the CF wrapped tank }\end{array}$ \\
\hline $\begin{array}{l}\text { Carbon Fiber (CF) } \\
\text { Type }\end{array}$ & Toray T700S & $\begin{array}{l}\text { Discussions with Quantum and other developers, } \\
2008\end{array}$ \\
\hline $\begin{array}{l}\text { CF Composite } \\
\text { Tensile Strength }\end{array}$ & $2,550 \mathrm{MPa}$ & Toray material data sheet for $60 \%$ fiber by volume \\
\hline $\begin{array}{l}\text { Adjustment for CF } \\
\text { Quality }\end{array}$ & $10 \%$ & $\begin{array}{l}\text { Reduction in average tensile strength to account } \\
\text { for variance in CF quality, based on discussion } \\
\text { with Quantum and other developers, } 2010\end{array}$ \\
\hline $\begin{array}{l}\text { CF Translation } \\
\text { Efficiency }\end{array}$ & $\begin{array}{l}\text { 350-bar: } 82.5 \% \\
700-\text { bar: } 80.0 \%\end{array}$ & $\begin{array}{l}\text { Assumption based on data and discussions with } \\
\text { Quantum, 2004-09 }\end{array}$ \\
\hline $\begin{array}{l}\text { Tank Liner } \\
\text { Thickness }\end{array}$ & $\begin{array}{c}5 \text { mm HDPE (Type IV) } \\
\text { 7.4 mm Al (Type III, 350-bar) } \\
12.1 \text { mm Al (Type III, 700-bar) }\end{array}$ & $\begin{array}{l}\text { Discussions with Quantum for Type IV tanks, } \\
\text { 2008; ANL calculations for Type III tanks }\end{array}$ \\
\hline Liner Cycle Life & 5500 cycles & SAE J 2579 \\
\hline Overwrap & $1 \mathrm{~mm}$ glass fiber & $\begin{array}{l}\text { Discussions with Quantum, 2008; common but not } \\
\text { functionally required }\end{array}$ \\
\hline $\begin{array}{l}\text { Protective End } \\
\text { Caps }\end{array}$ & $10 \mathrm{~mm}$ foam & $\begin{array}{l}\text { Discussions with Quantum, 2008; for impact } \\
\text { protection }\end{array}$ \\
\hline
\end{tabular}




\section{Performance Model}

Working with Quantum, we set up a design and performance model of a Type IV compressed tank system. Developing such a model enabled us to scale the tank system design to different sizes, for example, for providing $5.6 \mathrm{~kg}$ of usable hydrogen rather than the smaller sizes typical in current designs for demonstration hydrogen FCVs. We used the Benedict-Webb-Rubin equation of state to calculate the amount of stored $\mathrm{H}_{2}$ for $5.6 \mathrm{~kg}$ of recoverable $\mathrm{H}_{2}$ at 20-bar minimum delivery pressure. The model used a netting analysis algorithm to determine the optimal dome shape with a geodesic winding pattern, and to determine the thickness of the geodesic and hoop windings in the cylindrical section for specified maximum storage pressure and length-to-diameter ratio (L/D). Our model was validated by comparing the computed CF weights and volumes with Quantum's analysis and data. The agreement was within $1 \%$ for the 350-bar tank, and within 10\% for the 700-bar tank.

Filament winding is one of the most popular and affordable techniques for high performance composite structures, such as pressure vessels, fuel tanks, pipes and rocket motor cases. However, winding patterns vary, depending on the manufacturing process, fiber layout, machine accuracy, and cost [Lee 1993]. Since filament-wound composite pressure vessels are prone to fail in their dome sections, the design of the dome is critical to their structural stability. For given length-todiameter (L/D) and boss opening-to-diameter ratios, the optimal dome shape was generated using geodesic winding in accordance with Vasiliev and Morozov [2001]. Geodesic winding involves having the fiber filaments wound along the isotensoids. In the cylindrical section, the filament paths include both geodesic and hoop windings. In calculating the carbon fiber composite thickness, the model applied a safety factor of 2.25 and a translation efficiency of $82.5 \%$ and $82.0 \%$ [Liu 2009] to the tensile strength of the composite (2,550 MPa) for the 350and 700-bar systems, respectively. Based on recent data and feedback from tank developers [Newhouse 2010], we reduced the CF strength in our analyses by $10 \%$ to account for the variability in CF quality at high-volume manufacturing. Our on-board performance results include sensitivity analyses that cover a range of translation efficiencies for both the 350- and 700-bar systems.

Beyond the main tank assembly, the model included balance-of-plant (BOP) components shown in Figure 1. The weight ( $19 \mathrm{~kg})$ and volume ( $\sim 6 \mathrm{~L})$ of BOP components were estimated from commercial sources and were the same for the 350- and 700-bar systems.

In addition to the performance model for Type IV single tank systems that formed the initial scope of our analysis, we expanded our physical storage model to include the effects of autofrettage on the fatigue life of metal liners (aluminum) in Type III pressure vessels, and on the load distribution between the liner and the carbon fiber (CF). We modeled the autofrettage process applied to composite tanks for service at ambient and cryogenic temperatures. For service at ambient temperatures we determined the induced residual compressive stresses in the metal liner and tensile stresses in the CF. We used the model to determine the liner and CF thicknesses to meet the target life of 5500 pressure cycles at $25 \%$ over the nominal working pressure [SAE J2579, SAE International, 2009]. 


\section{Cost Model}

We applied a proprietary technology-costing methodology that has been customized to analyze and quantify the processes used in the manufacture of hydrogen storage tanks and BOP components. The bottom-up, activities-based, cost model is used in conjunction with the conventional Boothroyd-Dewhurst Design for Manufacturing \& Assembly (DFMA®) software. The model was used to develop costs for all the major tank components, balance-of-tank, tank assembly, and system assembly. The DFMA ${ }^{\circledR}$ concurrent costing software was used to develop bottom-up costs for other BOP components. Bottom-up costing refers to developing a manufacturing cost of a component based on:

- Technology Assessment - Seek developer input, conduct literature and patent reviews.

- Cost Model Development - Define manufacturing process unit operations, specify equipment, obtain cost of raw materials and capital equipment, define labor rates, building cost, utilities' cost, tooling cost, and cost of operating \& non-operating capital with appropriate financial assumptions:

o Fixed Operating Costs include Tooling \& Fixtures Amortization, Equipment Maintenance, Indirect Labor, and Cost of Operating Capital.

o Fixed Non-Operating Costs include Equipment \& Building Depreciation, Cost of Non-Operating Capital.

o Variable Costs include Manufactured Materials, Purchased Materials, Direct Labor (Fabrication \& Assembly), Indirect Materials, and Utilities.

- Model Refinement - Seek developer and stakeholder feedback, perform single-variable sensitivity and multi-variable Monte Carlo analyses.

We contacted developers/vendors, and performed a literature and patent search to explicate the component parts, specifications, material types and manufacturing processes. Subsequently, we documented the bill-of-materials (BOM) based on the system performance modeling, determined material costs at the assumed production volume, developed process flow charts, and identified appropriate manufacturing equipment. We also performed single-variable and multi-variable (Monte Carlo) sensitivity analyses to identify the major cost drivers and the impact of material price and process assumptions on the high-volume hydrogen storage system cost results. Finally, we solicited developer and stakeholder feedback on the key performance assumptions, process parameters, and material cost assumptions; and we calibrated the cost model using this feedback. A brief discussion of the key performance, process, and cost assumptions is presented below.

\section{Performance Parameters}

Key performance assumptions such as those presented in Table 1 were developed based on modeling and data from Quantum's Type IV tank design. We used sensitivity analyses to capture the impact of variation in key performance assumptions including tank safety factor, composite tensile strength, and translation efficiency.

\section{Carbon Fiber Price}

The cost of carbon fiber is a significant factor in all high-pressure systems. In order to maintain a common basis of comparison with previous cost analyses, we chose a base case carbon fiber price of $\$ 13 / \mathrm{lb}$ (\$28.6/kg) based on discussions with Toray in 2007 regarding the price of T700S 
fiber at high volumes. Carbon fiber is already produced at very high-volumes for the aerospace and other industries, so it isn't expected to become significantly less expensive in the near term. However, there are DOE programs that are investigating ways to significantly reduce carbon fiber costs (e.g., Abdallah 2004). We used sensitivity analyses to capture the impact of the uncertainty in carbon fiber prices, using \$10/lb at the low end and \$16/lb at the high end.

We assumed the hydrogen storage system manufacturer purchases pre-impregnated (referred to as "prepreg”) carbon fiber composite at a price that is 1.27 times (prepreg/fiber cost ratio) the cost of the raw carbon fiber material [Du Vall 2001]. An alternative approach would be to assume a wet resin winding process that would allow the purchase of raw carbon fiber material instead of buying prepreg tow fiber. We chose a prepreg winding process, based on the assumption that this process results in greater product throughput and reduced environmental hazards (including VOCs, ODCs, and GHG emissions) compared to a wet winding process. According to Du Vall, greater throughput is typically achieved because prepreg tow allows for more precise control of resin content, yielding less variability in the cured part's mechanical properties and ensuring a more consistent, reproducible, and controllable material, compared to wet winding. In addition, wet winding delivery speeds are limited due to the time required to achieve good fiber/resin wet out. The downside is that the prepreg raw material costs are higher than for wet winding. But, when all aspects of the finished product cost are considered (i.e., labor, raw materials, throughput, scrap, downtime for cleanup, and costs associated with being environmentally compliant), Du Vall found that prepreg materials provided an economic advantage compared to wet winding for high-volume production of Type II and IV compressed natural gas (CNG) tanks.

It might be possible to reduce the overall manufactured cost of the CF composite, perhaps closer to the cost per pound of the carbon fiber itself $(\$ 13 / \mathrm{lb})$ or ever lower (since the resin is less expensive per pound), if the wet winding process is proven to be more effective, in particular, if wet winding throughputs are increased. However, the detailed evaluation that is required to explore these cost trade-offs was beyond the current scope of work. Instead, we address the potential impact of significantly lower carbon fiber composite costs by the sensitivity analysis.

\section{BOP Cost Projections}

BOP costs were estimated using the Delphi method, with validation from top-down and bottomup estimates described below (see Appendix B for details for each cost estimation approach).

- Delphi Method: Projections solicited from industry experts, including suppliers, tank developers, and end users.

o End users (e.g., automotive OEMs) and, to some extent, tank developers, are already considering the issues of automotive scale production volumes.

o In some cases, end-user or developer estimates are too low or based on unreasonable targets; in other cases estimates may be too high due to not taking into account process or technology developments that would be required for automotive-scale production volumes.

o We used our judgment of the projections and results from top-down and bottom-up estimations (see below) to select a reasonable base case cost for each component. 
- Top-Down: High-volume discounts applied to low-volume vendor quotes using progress ratios (PR).

o Provides a consistent way to discount low-volume quotes.

o Attempts to take into account process or technology developments that would be required for automotive-scale production volumes.

o Requires an understanding of current base costs, production volumes, and markups.

- Bottom-Up: Cost Modeling using DFMA ${ }^{\circledR}$ software.

o Calculates component costs using material, machining, and assembly costs, plus an assumed 15\% markup for component supplier overhead and profit.

o May not be done at the level of detail necessary for estimating the true high-volume manufactured cost of the component.

\section{Vertically Integrated Process vs. Outsourcing of Tank Components}

In reporting the "Factory Cost" or "Manufactured Cost" of the hydrogen storage system, we have assumed a vertically integrated tank manufacturing process; i.e., we assumed that the automotive OEM or car company makes all the tank components in-house. Therefore, intermediate supply chain markups are not included for individual tank components. The major tank costs (liner, carbon fiber layer, and tank assembly) are "bottom-up" estimated, and reported with no added supplier markup. In practice, the manufacturing process is likely to be a combination of horizontally (procured) and vertically (manufactured in-house) steps, with appropriate markups.

\section{Markup of BOP Components}

In our model, some major BOP costs (e.g., fill tube/port, pressure regulator, pressure relief valve) are "bottom-up" estimated as well (similar to the major tank costs). Since we assume that the automotive OEM buys all the BOP components/subsystems from suppliers, and assembles the overall system in-house, we assume a uniform supplier-to-automotive OEM markup of $15 \%$ for all major BOP components. Raw materials and some BOP hardware are purchased and implicitly include (an unknown) markup. We assume that supplier markup includes cost elements for:

- Profit

- $\quad$ Sales (Transportation) \& Marketing

- $\quad$ R\&D - Research \& Development

- G\&A - General \& Administration (Human Resources, Accounting, Purchasing, Legal, and Contracting), Retirement, Health

- Warranty

- Taxes

Based on discussions with industry, we learned that automotive Tier 1 suppliers would most likely not have any Sales \& Marketing expense since they often have guaranteed 5-year supply contracts with the OEMs. Also, the warranty and R\&D cost is increasingly being shared by the supplier and the OEM. (Previously, the OEM covered the warranty costs themselves; now the supplier supports their own warranty; furthermore, the OEMs share in some of the R\&D costs). The OEMs usually negotiate 5\% per year cost reduction for 5 years with the supplier, further squeezing the supplier's margin. Therefore, currently, profit margins for Tier 1 suppliers are typically only in the single-digits (perhaps 5-8\%), with a 15\% markup being rare. We address 
these markup uncertainties and other BOP component cost uncertainties by the sensitivity analyses. ${ }^{1}$

\section{Tank QC and System QC}

At the high production volume of 500,000 units/year, we have assumed that the hydrogen storage system production process is mature and that all quality issues are "learned out". We have included only rudimentary tank and system Quality Control (QC) such as leak tests and visual and ultrasonic inspections.

\section{Process Yield, Material Scrap and Reject Rate}

The cost models include assumptions about Process Yield (i.e., the percentage of acceptable parts out of the total parts that are produced), Material Scrap Rate (i.e., the recyclable left-over material out of the total materials used in the process), and Reject Rate (i.e., the percentage of unacceptable parts out of the total parts that are produced) based on experience from similar manufacturing processes at high-volumes. An appropriate material scrap credit is applied to the left-over material; however, the material recycling process was not included in the scope of our analysis. We address the impacts of uncertainties in these assumptions by the sensitivity analyses.

\section{Other Technical Issues}

The goal of this assessment was to capture the major cost contributions to the overall hydrogen storage system cost. The system chosen for assessment does not necessarily solve all of the technical issues facing developers today. For example, the costs of added vehicle controls required to operate the storage system are not included, nor are the costs of hydrogen leak detection sensors and controls included. These BOP components are not expected to make a significant contribution to the total storage system cost at present; however, if the costs of the tank and major BOP components decrease significantly, the balance of the system may represent a larger proportion of the total system cost in the future.

\section{Performance Results for Type IV Single Tank Systems}

The results of the performance analyses indicate that both the 350- and the 700-bar base case systems exceed the DOE 2010 gravimetric target of $4.5 \mathrm{wt} \%{ }^{2}$ and that the 350-bar system also meets the 2015 target of $5.5 \mathrm{wt} \%$. The gravimetric capacity of the 700 -bar system is about $24 \%$ lower than the 2015 target, however, despite the intrinsically higher density of the stored hydrogen, due to the weight of the additional CF composite required to withstand the higher pressure (25.9-mm thick CF layer for the 700-bar tank versus $14.7 \mathrm{~mm}$ for the 350-bar tank). Further, the volumetric capacities of the two systems are 6 and 37\% lower than the DOE 2010 target of $28 \mathrm{~g} \mathrm{H}_{2} / \mathrm{L}$ and 34 and 56\% lower than the DOE 2015 target of $40 \mathrm{~g} \mathrm{H}_{2} / \mathrm{L}$ for the 700-bar and 350-bar systems, respectively. Indeed, the density of the compressed hydrogen gas by itself at these pressures (and room temperature) makes it impossible to meet the 2015 volumetric target. Neither system is projected to be able to meet the ultimate DOE gravimetric or volumetric

\footnotetext{
${ }^{1}$ The supplier markup does not include the markup for the hydrogen storage system manufacturer (e.g. automotive OEM) that sells the final assembled system.

${ }^{2} \mathrm{Wt} \%$ is defined here as the weight of usable hydrogen (i.e., $5.6 \mathrm{~kg}$ ) divided by total tank system weight.
} 
capacity targets of $7.5 \mathrm{wt} \%$ and $70 \mathrm{~g} / \mathrm{L}$. These results are summarized in Table I. Detailed performance results are given in Appendix A.

The weight and volume distributions are shown in Figure 2 for the two base case scenarios. For the 350-bar tank system, the carbon fiber accounts for 53\% of the total system weight and $10 \%$ of the system volume. Other contributors to the system weight are the liner (11\%), glass fiber (6\%), foam (5\%), $\mathrm{H}_{2}(6 \%)$, and BOP (19\%). The largest contributor to the 350-bar tank system volume is the stored $\mathrm{H}_{2}$ (81\%), with less than 5\% each of the liner, foam, glass fiber, and the BOP. For the 700-bar tank system, the carbon fiber accounts for $62 \%$ of the system weight, BOP $17 \%$, liner $7 \%$, with the $\mathrm{H}_{2}$, foam, and glass fiber each accounting for $5 \%$ or less of the total system weight; the two major contributors to the system volume are the stored $\mathrm{H}_{2}(70 \%)$ and the carbon fiber (20\%), with $4 \%$ or less of liner, foam, glass fiber, and the BOP.

Weight Distribution (\%) 350 bar, $5.6 \mathrm{~kg}$ Usable $\mathrm{H}_{2}$

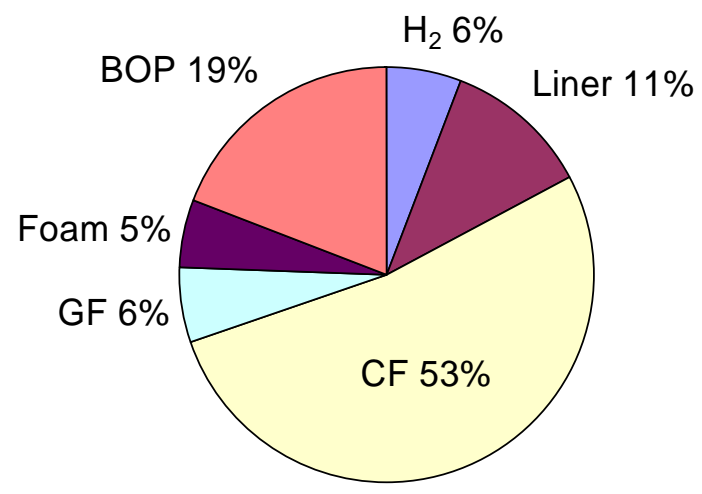

Weight Distribution (\%) 700 bar, 5.6 kg Usable $\mathrm{H}_{2}$

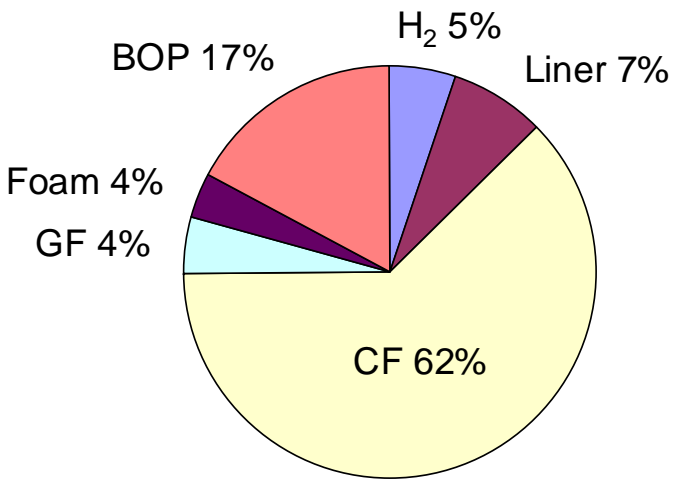

\section{Volume Distribution (\%) 350 bar, $5.6 \mathrm{~kg}$ Usable $\mathrm{H}_{2}$}

Liner 4\%

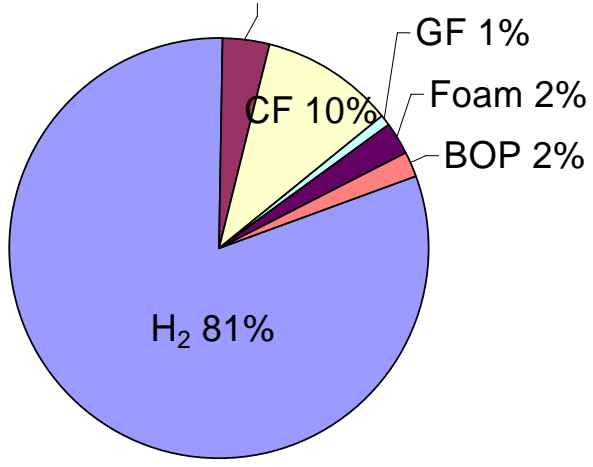

Volume Distribution (\%)

700 bar, 5.6 kg Usable $\mathrm{H}_{2}$

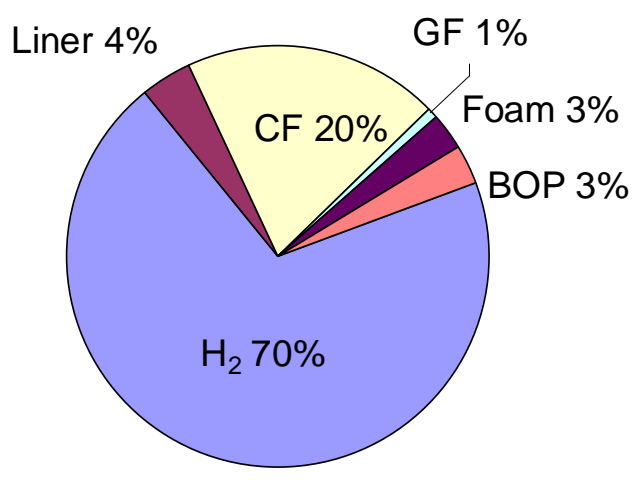

Figure 2: Base case weight and volume distributions for the compressed hydrogen storage systems 
As shown in Figure 3, the gravimetric capacity of the 350-bar system is $5.5 \mathrm{wt} \%$, which increases to $5.8 \mathrm{wt} \%$ if the design "empty" pressure is reduced to $3 \mathrm{bar}$ ( $\sim 5 \mathrm{psia}$ ) and to $5.7 \mathrm{wt} \%$ if the CF translation efficiency improves to $90 \%$ with assumed advances in filament winding technology. The gravimetric capacity for the 350-bar system with 20-bar empty pressure approaches $6.0 \mathrm{wt} \%$ if the CF translation efficiency reaches the ultimate, or theoretical, value of $100 \%$. The gravimetric capacity of the base case 700-bar system is $5.2 \mathrm{wt} \%$, which increases to $5.3 \mathrm{wt} \%$ if the "empty" pressure is reduced to $3 \mathrm{bar}$ ( $45 \mathrm{psia}$ ) and to $5.6 \mathrm{wt} \%$ if the CF translation efficiency is increased to $90 \%$. The gravimetric capacity for the 700-bar system with 20-bar empty pressure approaches $5.9 \mathrm{wt} \%$ if the CF translation efficiency reaches $100 \%$.

Varying other design parameters, such as the tank length-to-diameter ratio to between 2 and 4, has relatively little effect ( $0.1 \mathrm{wt} \%)$ on the gravimetric capacity of the two systems.

For the base case conditions, the stored hydrogen accounts for about $81 \%$ of the total volume of the 350-bar system, and for about $70 \%$ of the total volume of the 700-bar system. As shown in Figure 3, reducing the empty pressure from 20 bar to 3 bar increases the volumetric capacity

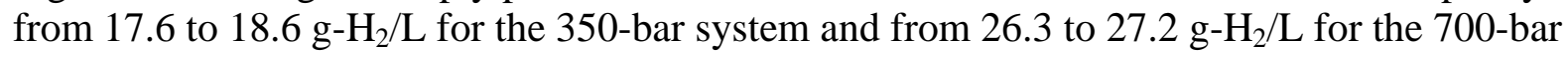
system. Improving the winding process to obtain $90 \% \mathrm{CF}$ translation efficiency increases the volumetric capacity from 17.6 to $17.7 \mathrm{~g}-\mathrm{H}_{2} / \mathrm{L}$ for the 350-bar system and from 26.3 to $26.9 \mathrm{~g}$ $\mathrm{H}_{2} / \mathrm{L}$ for the 700-bar system. The volumetric capacity assuming $100 \% \mathrm{CF}$ translation efficiency approaches 17.8 g- $\mathrm{H}_{2} / \mathrm{L}$ for the 350-bar system and $27.5 \mathrm{~g}-\mathrm{H}_{2} / \mathrm{L}$ for the 700 -bar system. Varying other performance assumptions, such as the tank length-to-diameter ratio, has only a small effect on the volumetric capacity of the systems.

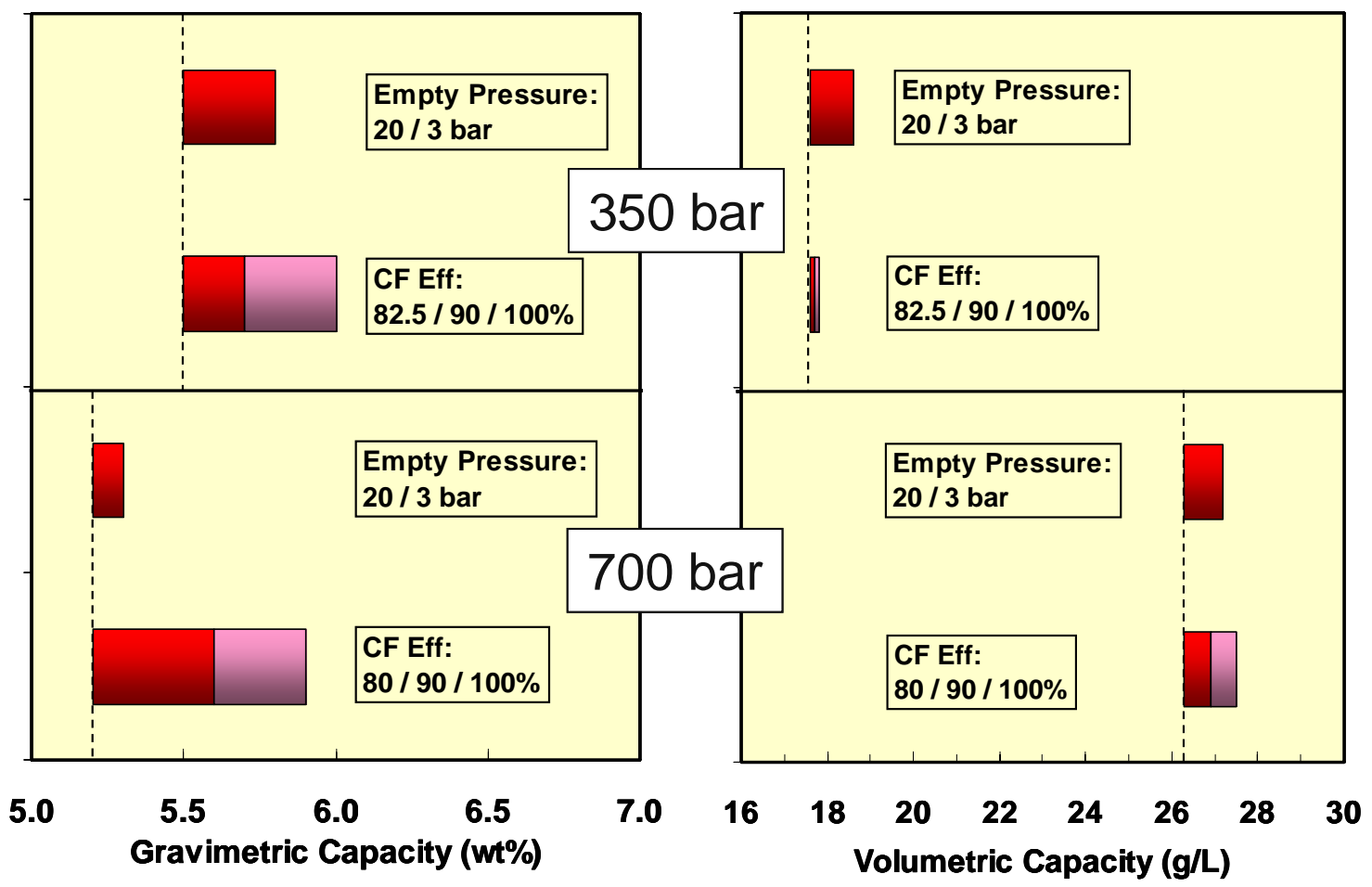

Figure 3: Gravimetric and volumetric capacities of compressed hydrogen storage systems, and their sensitivity to tank empty pressure and carbon fiber translation efficiency. 


\section{Cost Results}

We evaluated the costs of compressed 350- and 700-bar onboard storage systems for Type III and Type IV pressure vessels, and for single- and dual-tank configurations. Our cost assessment projects that the 350- and 700-bar on-board storage systems will cost 4-5 times the DOE 2010 cost target of $\$ 4 / \mathrm{kWh}$, even at high production volumes. Dual-tank systems are projected to cost on about $\$ 0.5 / \mathrm{kWh}$ more than single-tank systems. Type III tanks are projected to cost $\$ 1.2$ to $\$ 2.2 / \mathrm{kWh}$ more than Type IV tanks for the 350-bar and 700-bar tanks, respectively. The discussion in the following paragraphs focuses primarily on Type IV, single-tank systems; additional discussion of the Type III and dual-tank systems is included near the end.

As seen in Figure 4, the main cost contributor to single-tank Type IV systems is the carbon fiber composite layer, which accounts for approximately $75 \%$ and $80 \%$ of the base case 350 - and 700-bar system costs, respectively.

As shown in Table 2, processing cost makes up just 5\% of the total system cost due to the assumed high production volumes and number of purchased components. This processing cost fraction is low, compared to the current cost to manufacture similar tanks systems.

Manufacturing a compressed tank today using relatively low-volume production techniques requires more complex and labor intensive processes due to the high-pressure requirement (i.e.., carbon fiber wrapped tank). There is uncertainty and disagreement among different developers and automotive OEMs about the level of automation that can be achieved in the future, but we have assumed that substantial cost savings would occur with economies of scale, once high production volumes are achieve over a sustained period of time. Similarly, we have assumed BOP component costs would be much lower than today's vendor quotes for similar components at the current low volumes of manufacture (see Appendix B for details).

Type IV 350-bar Factory Cost ${ }^{1}=\$ 2,900$ $\$ 15 / \mathrm{kWh}$ based on $5.6 \mathrm{~kg}$ usable $\mathrm{H}_{2}\left(6 \mathrm{~kg}\right.$ stored $\left.\mathrm{H}_{2}\right)$

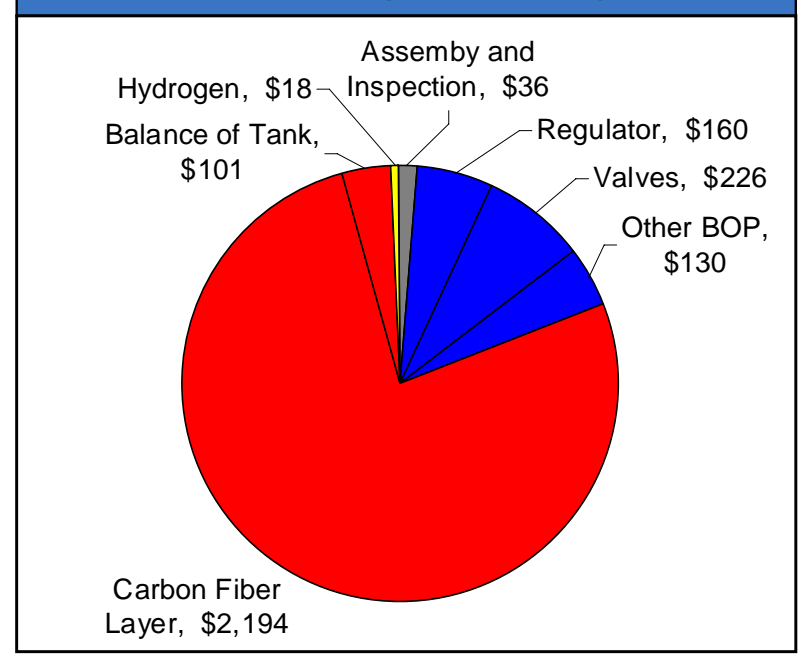

${ }^{1}$ Cost estimate in 2005 USD. Includes processing costs.
Type IV 700-bar Factory Cost ${ }^{1}=\$ 3,500$ $\$ 19 / \mathrm{kWh}$ based on $5.6 \mathrm{~kg}$ usable $\mathrm{H}_{2}\left(5.8 \mathrm{~kg}\right.$ stored $\left.\mathrm{H}_{2}\right)$

Carbon Fiber Layer, \$2,721

Figure 4: Base case component cost breakout for the compressed hydrogen storage systems. 
Table 2: Base case material versus processing cost breakout for compressed hydrogen storage systems

\begin{tabular}{|l|c|c|c|c|c|c|}
\hline \multirow{2}{*}{$\begin{array}{c}\text { On-board System Cost } \\
\text { Breakout - Compressed Gas }\end{array}$} & \multicolumn{3}{|c|}{ Type IV 350-bar Base Case } & \multicolumn{3}{c|}{ Type IV 700-bar Base Case } \\
\cline { 2 - 7 } & $\begin{array}{c}\text { Material, } \\
\$\end{array}$ & $\begin{array}{c}\text { Processing, } \\
\$\end{array}$ & $\begin{array}{c}\text { Processing } \\
\text { Fraction }\end{array}$ & $\begin{array}{c}\text { Material, } \\
\$\end{array}$ & $\begin{array}{c}\text { Processing, } \\
\$\end{array}$ & $\begin{array}{c}\text { Processing } \\
\text { Fraction }\end{array}$ \\
\hline Hydrogen & $\$ 18$ & (purchased) & - & $\$ 18$ & (purchased) & - \\
\hline Compressed Vessel & $\$ 2,193$ & $\$ 102$ & $4 \%$ & $\$ 2,681$ & $\$ 119$ & $4 \%$ \\
Liner \& Fittings & $\$ 20$ & $\$ 11$ & $34 \%$ & $\$ 14$ & $\$ 10$ & $43 \%$ \\
Carbon Fiber Layer & $\$ 2,111$ & $\$ 83$ & $4 \%$ & $\$ 2,619$ & $\$ 102$ & $4 \%$ \\
Glass Fiber Layer & $\$ 30$ & $\$ 7$ & $18 \%$ & $\$ 23$ & $\$ 6$ & $21 \%$ \\
Foam & $\$ 32$ & $\$ 2$ & $5 \%$ & $\$ 25$ & $\$ 1$ & $5 \%$ \\
\hline Regulator & $\$ 160$ & (purchased) & - & $\$ 200$ & (purchased) & - \\
\hline Valves & $\$ 226$ & (purchased) & - & $\$ 282$ & (purchased) & - \\
\hline Other BOP & $\$ 130$ & (purchased) & - & $\$ 155$ & (purchased) & - \\
\hline Final Assembly \& Inspection & - & $\$ 36$ & - & - & $\$ 36$ & - \\
\hline Total Factory Cost & $\$ 2,727$ & $\$ 138$ & $\mathbf{5 \%}$ & $\mathbf{\$ 3 , 3 3 4}$ & $\mathbf{1 5 6}$ & $\mathbf{4} \%$ \\
\hline
\end{tabular}

Single-variable sensitivity analyses were performed by varying one parameter at a time, while holding all others constant. We varied the overall manufacturing assumptions, economic assumptions, key performance parameters, direct material cost, capital equipment cost, and process cycle time for individual components. According to the single variable sensitivity analysis results, the range of uncertainty for the tank's carbon fiber purchased cost and safety factor assumptions have the biggest impact on the total system cost projections (i.e., sensitivity results for these assumptions are roughly 15-20\% of the total system cost each).

Multi-variable (Monte Carlo) sensitivity analyses were performed by varying all the parameters simultaneously, over a specified number of trials, to determine a probability distribution of the cost. We assumed a triangular Probability Distribution Function (PDF) for the parameters, with the "high" and "low" values of the parameter corresponding to a minimum probability of occurrence, and the base case value of the parameter corresponding to a maximum probability of occurrence. The parameters and ranges of values considered were the same as for the singlevariable sensitivity analysis. According to the multi-variable sensitivity analysis results, the system factory cost will likely range between $\$ 10.6$ and $\$ 19.7 / \mathrm{kWh}$ for the 350-bar system and between $\$ 13.5$ and $\$ 27.2 / \mathrm{kWh}$ for the 700 -bar system. ${ }^{3}$ These results are compared to DOE cost targets in Table 3. Detailed assumptions and results are given in Appendix B.

Table 3: Summary results of the on-board cost assessment for 350- and 700-bar compressed hydrogen storage systems compared to DOE cost targets

\begin{tabular}{|c|c|c|c|c|}
\hline $\begin{array}{c}\text { Cost Projections, } \\
\text { \$/kWh }\end{array}$ & 350-bar System & 700-bar System & 2010 Target & 2015 Target \\
\hline High & 19.7 & 27.2 & & \\
\hline Base Case & 15.4 & 18.7 & 4 & 2 \\
\hline Low & 10.6 & 13.5 & & \\
\hline
\end{tabular}

\footnotetext{
${ }^{3}$ Range is defined here as the $95 \%$ confidence interval based on the data fit for the sensitivity analyses.
} 
These costs compare well to industry factory cost projections for similarly sized tanks at lower production volumes. ${ }^{4}$ Industry factory cost projections for medium-volume manufacturing (i.e., 1,000 units per year) range from $\$ 45-55 / \mathrm{kWh}$ for 350-bar tank systems and \$55-65/kWh for 700-bar tank systems without valves and regulators. Removing valve and regulator costs from the base case cost projections results in a high-volume (500,000 units per year) factory cost of $\$ 13 / \mathrm{kWh}$ and $\$ 16 / \mathrm{kWh}$ for 350-bar and 700-bar tank systems, respectively. These results compare well to the lower-volume industry projections assuming progress ratios of $85-90 \% .^{5}$ While this progress ratio range is reasonable, it is perhaps a bit on the high end of what would be expected (progress ratios of $60-90 \%$ are typical) due to carbon fiber representing such a large fraction of the overall system cost. Unlike other system components, carbon fiber is already produced at high volumes for the aerospace and other industries, so it is not expected to become significantly less expensive due to the typical learning curves assumed by projections based on progress ratios. ${ }^{6}$

\section{Assessment of Type III Tanks and Dual-Tank Systems}

In addition to the performance and cost projections for Type IV, single tank systems that formed the initial scope of our analyses, we conducted analyses of Type III (aluminum-lined) tanks and of dual-tank systems. These two alternative configurations offer several potentially attractive characteristics:

- Dual-tank systems offer packaging flexibility compared to single-tank systems, which has the potential to mitigate issues associated with the relatively large footprint of compressed gas hydrogen storage systems.

- Type III tanks may offer cost and volume advantages compared to Type IV tanks, because the aluminum liner can support a portion of the pressure load, thereby reducing the amount of carbon fiber required.

We assumed that the dual-tank system design utilizes a single balance-of-plant subsystem (see Figure 5). This assumption is not consistent with current CNG dual-tank designs, in which two redundant balance-of-plant subsystems are typically employed. However, it was assumed that future high volume systems would likely employ the simpler design used in this analysis

\footnotetext{
${ }^{4}$ Industry projections are for 100-120 liter water capacity tanks versus 149-258 liter water capacity tank designs evaluated here.

${ }^{5}$ The progress ratio (pr) is defined by speed of learning (e.g., how much costs decline for every doubling of capacity).

${ }^{6}$ However, there are DOE programs that are looking at ways to significantly decrease carbon fiber costs [Abdallah 2004].
} 


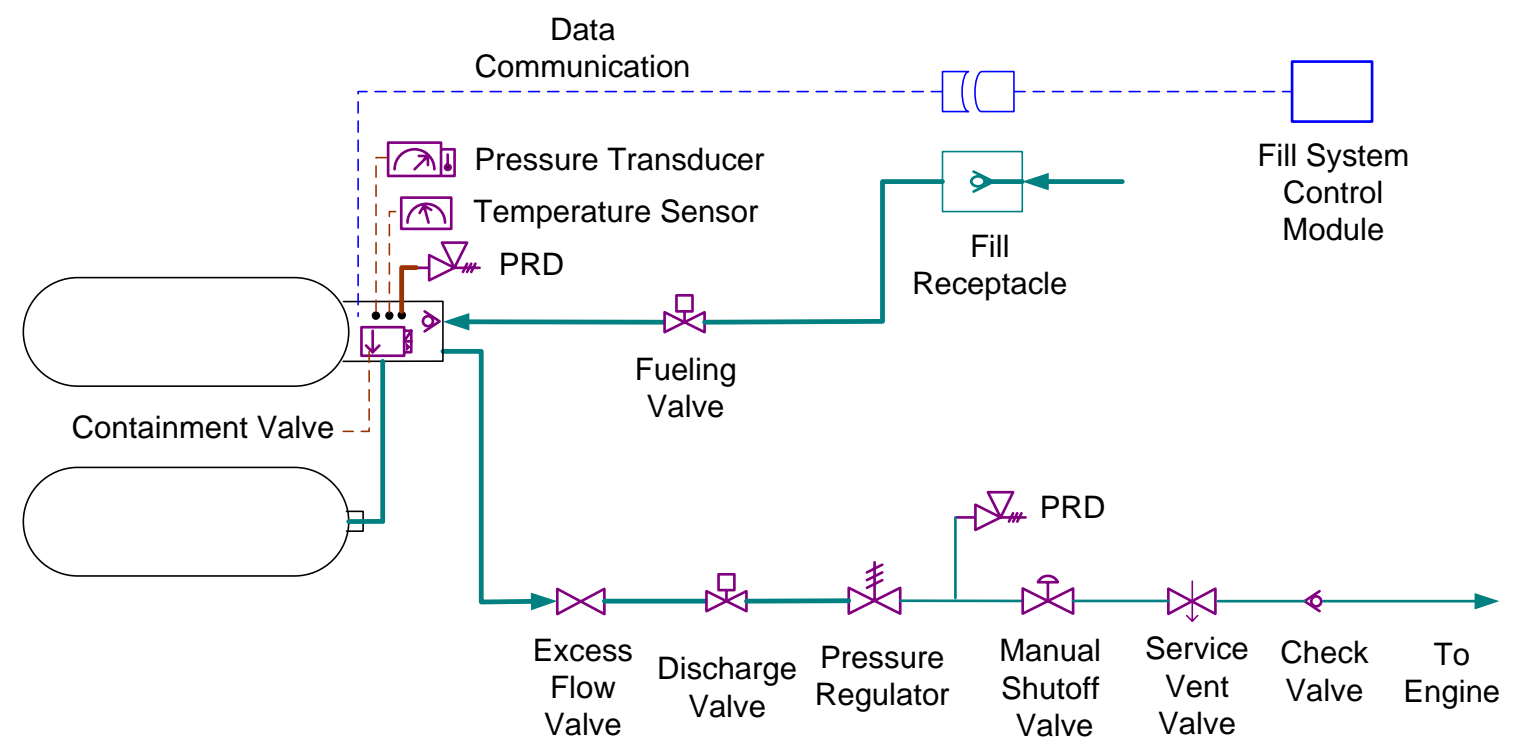

Figure 5: Schematic of dual-tank compressed hydrogen storage system.

Figure 6 shows the calculated gravimetric and volumetric capacities for Type III and Type IV, single- and dual-tank 350-bar systems. For single-tank systems, we calculate that the CF in a 350-bar, 5.6-kg usable $\mathrm{H}_{2}$, Type III tank system can carry $90 \%$ of the total load, the $\mathrm{Al}$ liner thickness is $7.4 \mathrm{~mm}$, and the usable storage capacities are $4.2 \mathrm{wt} \%$ and $17.4 \mathrm{~g} / \mathrm{L}$. The corresponding capacities for the Type IV tank system (5-mm HDPE liner) are higher, $5.5 \mathrm{wt} \%$ and $17.6 \mathrm{~g} / \mathrm{L}$. For dual-tank systems, we calculate that the Al liner thickness is $5.9 \mathrm{~mm}$ for Type III tanks, and the usable storage capacities are $4.0 \mathrm{wt} \%$ and $17.2 \mathrm{~g} / \mathrm{L}$. The corresponding capacities for the Type IV dual-tank system (5-mm HDPE liner) are higher, $5.0 \mathrm{wt} \%$ and $17.2 \mathrm{~g} / \mathrm{L}$.

Figure 7 shows the calculated system capacities for Type III and Type IV, single- and dual-tank 700-bar systems. For Type III single-tank systems, we calculate that the Al liner thickness is $12.1 \mathrm{~mm}$, and the usable storage capacities are $3.6 \mathrm{wt} \%$ and $25.0 \mathrm{~g} / \mathrm{L}$. The corresponding capacities for the Type IV tank system (5-mm HDPE liner) are higher, 5.2 wt\% and $26.3 \mathrm{~g} / \mathrm{L}$. Because the HDPE liner carries negligible load, the liner thickness is unchanged between 350-bar and 700 bar pressures. For dual tank systems, we calculate that the $\mathrm{Al}$ liner thickness is $9.6 \mathrm{~mm}$ for Type III tanks, and the usable storage capacities are $3.5 \mathrm{wt} \%$ and $24.7 \mathrm{~g} / \mathrm{L}$. The corresponding capacities for the Type IV dual-tank system (5-mm HDPE liner) are higher, $4.8 \mathrm{wt} \%$ and $25.6 \mathrm{~g} / \mathrm{L}$

We conclude that among the various compressed hydrogen tank systems analyzed, only the 350-bar, Type IV, single-tank system can potentially meet the 2015 gravimetric target of $5.5 \mathrm{wt} \%$ for $5.6 \mathrm{~kg}$ of recoverable hydrogen. None of the analyzed systems was found capable of meeting the 2015 volumetric target of $40 \mathrm{~g} / \mathrm{L}$. 


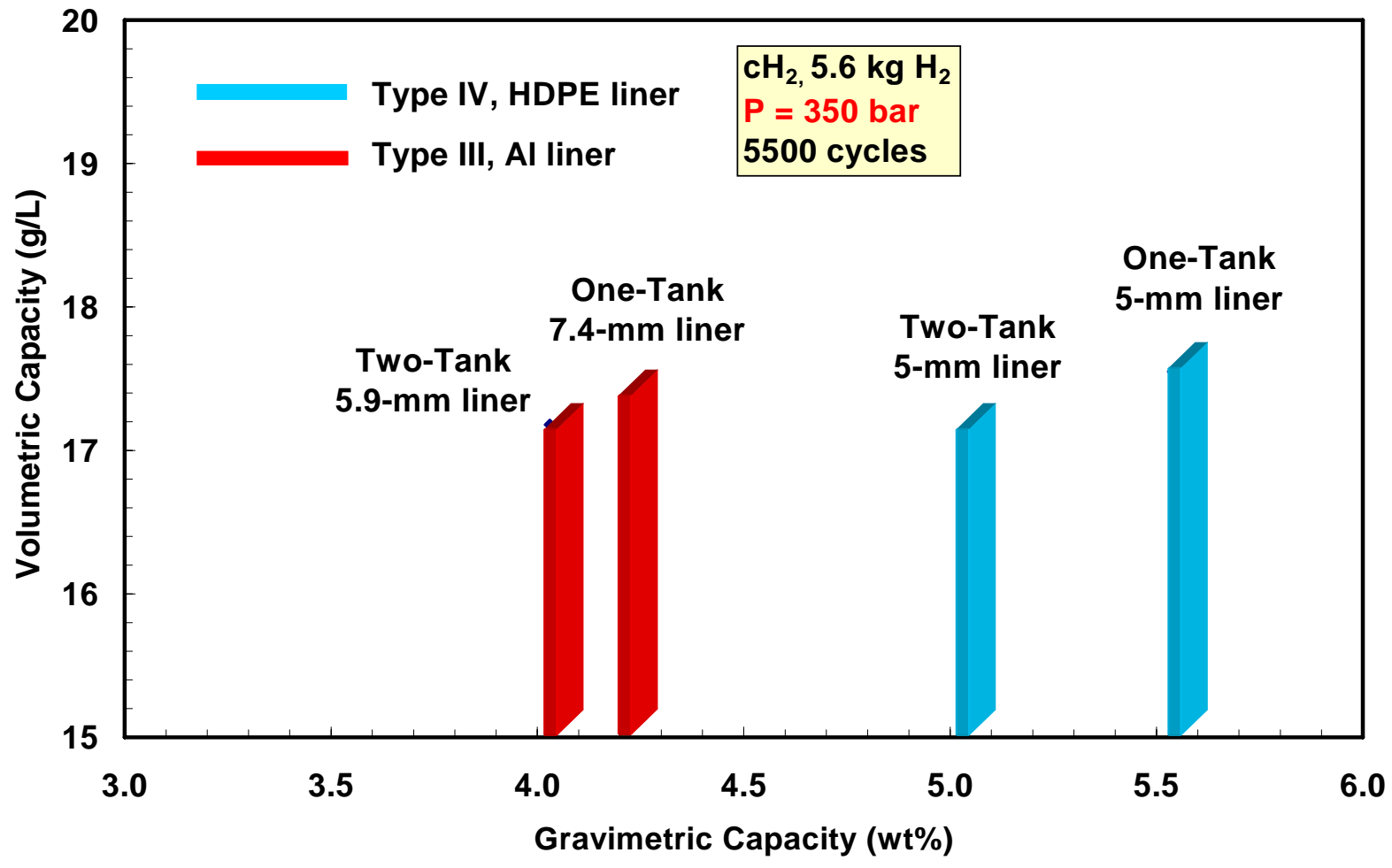

Figure 6: Comparison of the capacities of Type III and Type IV, single- and dual-tank, 350-bar hydrogen storage systems.

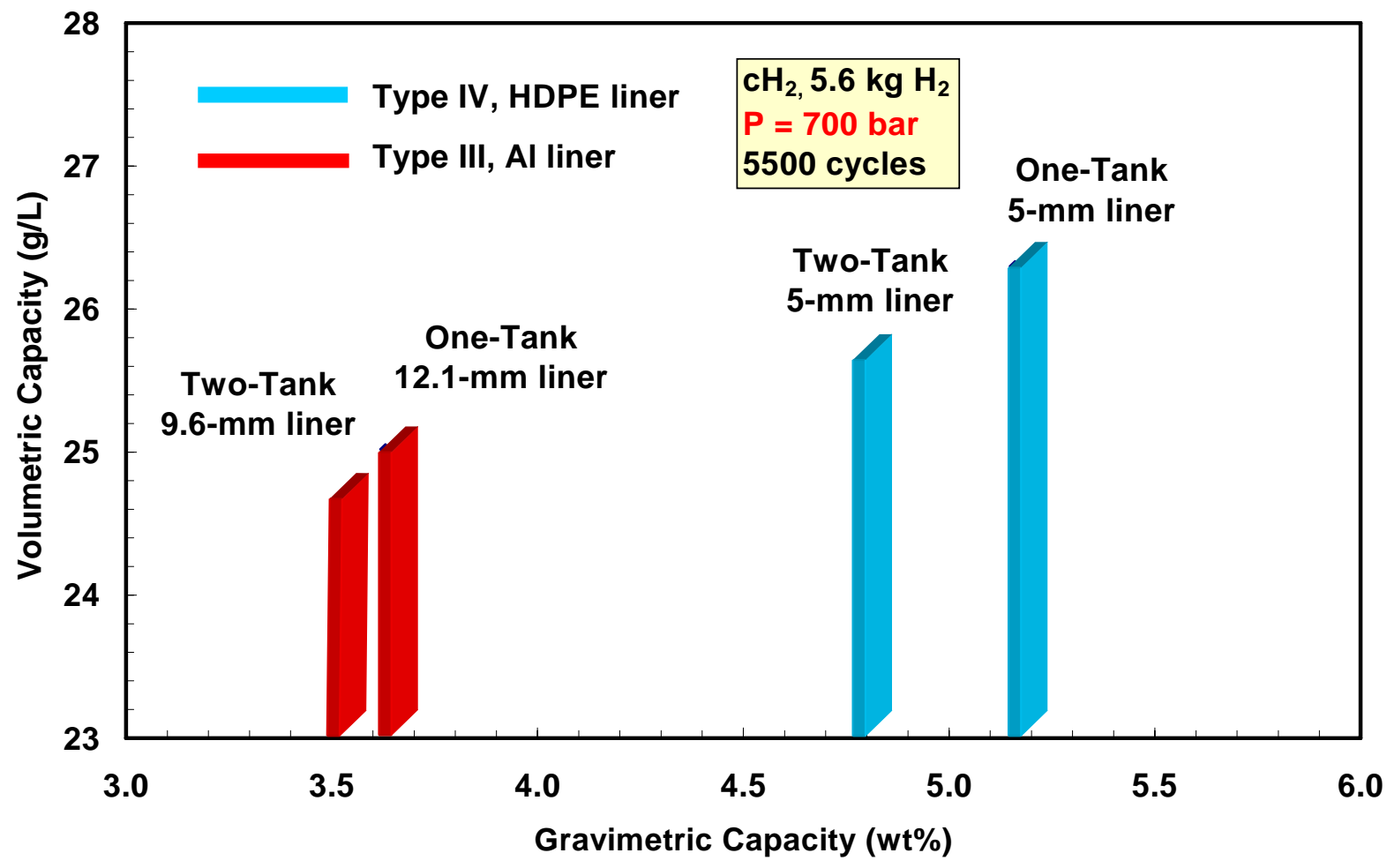

Figure 7: Comparison of the capacities of Type III and Type IV, single- and dual-tank, 700-bar hydrogen storage systems. 
The results of the independent performance analyses of the system gravimetric and volumetric capacities of Type III and Type IV tanks were compared with the DOE Hydrogen Storage Grand Challenge "Learning Demos" data [NREL 2009]. The comparison is generally favorable, although there are some differences that need further investigation (see Appendix A for the comparison).

Our cost projections assume that a similar manufacturing process and system design is used for each of the compressed gas system configurations. However, for Type III tanks, a minor adjustment was made to the Type IV manufacturing process to include an autofrettage step - a process that is used to increase the liner's fatigue life. For dual-tank systems, our cost analysis assumes that a single balance-of-plant subsystem is used to regulate both storage tanks. ${ }^{7}$

In total, eight different compressed system configurations were evaluated. These configurations include each combination of 350- and 700-bar, single- and dual-tank, and Type III and Type IV systems. A summary of the resulting cost projections is shown in Figure 8. For each of the systems analyzed, the tank comprises upwards of $80 \%$ of the system cost - primarily due to the high cost of the carbon fiber material. The Type IV, single-tank configurations are the lowest cost configurations for both the 350-bar and the 700-bar systems. The Type III configuration adds approximately $\$ 1.2 / \mathrm{kWh}$ and $\$ 2.2 / \mathrm{kWh}$ to the cost of the 350-bar and the 700-bar systems, respectively. A comparison of the price breakdown between Type III and Type IV systems (see Appendix B) indicates that, although the Type III tanks require less carbon fiber, this saving is more than offset by the additional expense of the aluminum liner compared to the HDPE liner.

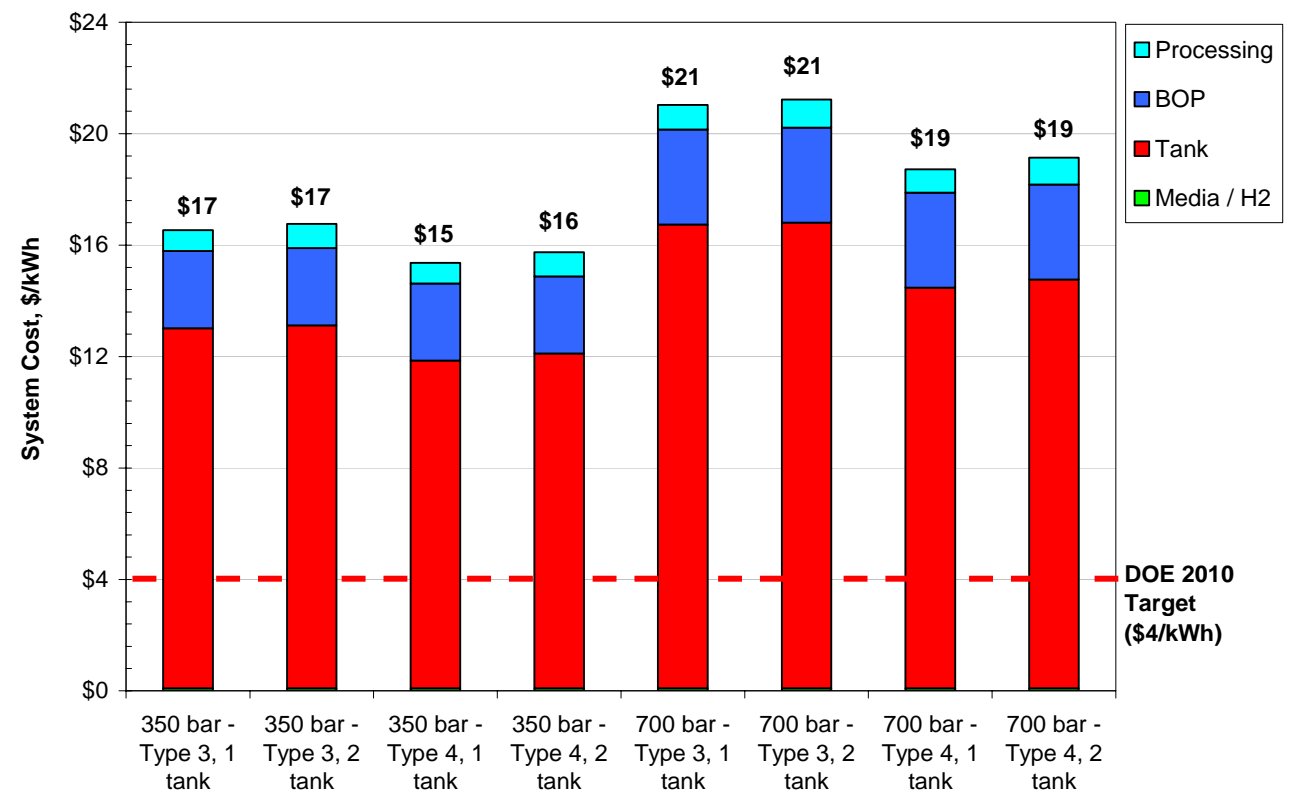

Figure 8: Comparison of system cost projections for Type III and Type IV, single- and dual-tank systems for 350-bar and 700-bar hydrogen storage.

\footnotetext{
${ }^{7}$ An alternate configuration using a redundant balance of plant configuration was assessed for sensitivity analyses.
} 
The dual-tank system adds less than $\$ 0.5 / \mathrm{kWh}$ to the cost of both the 350-bar and 700-bar singletank systems for Type III and Type IV systems. This result reflects a slightly higher material cost and a significantly higher processing cost, compared to a single-tank configuration:

- The pressure vessels used in the single-tank system require vessel walls that are approximately 25\% thicker than those needed for the smaller pressure vessels used in the dual-tank system. This increased thickness nearly counter-balances the lower surface area of the single tank. As such, the material cost for the dual-tank system is less than $5 \%$ higher than the material cost for an equivalent single-tank system.

- The processing costs are 15 to $20 \%$ higher for the dual-tank system, but processing costs account for only about $5 \%$ of the total system cost.

As noted above, the dual-tank system design assumes that both tanks use a single balance-ofplant subsystem. Results of a single-variable sensitivity analysis of the dual-tank system indicate that if a redundant balance-of-plant subsystem is used for each tank, system costs would increase by $\$ 2.7 / \mathrm{kWh}$ and $\$ 3.4 / \mathrm{kWh}$ compared to the single-tank, 350- and 700-bar systems, respectively.

\section{Off-board Assessments}

We evaluated the fuel cycle and infrastructure necessary to support refueling compressed hydrogen systems in automotive applications. These off-board assessments make use of existing, publicly available models to calculate the cost and performance of the hydrogen fuel cycle on a consistent basis. The performance assessment uses results from ANL's GREET [Wang 2005] and FCHtool [Ahluwalia 2007] models, while the cost assessment uses results from DOE's Hydrogen Delivery Scenarios Analysis Model, HDSAM [DOE 2009]. Key design assumptions for both analyses include central production via natural gas steam reforming (i.e., SMR), hydrogen delivery via compressed gas pipeline, and refueling to $25 \%$ over the nominal storage pressure (i.e., to 438 and 875 bar for 350 and 700 bar tanks, respectively). Additional design assumptions and details are listed in Table 4.

We performed an ownership cost analysis that included both on-board and off-board costs. Offboard (or refueling) costs for the complete fuel cycle necessary to support 350-bar and 700-bar compressed tank systems were estimated using DOE's Hydrogen Delivery Scenarios Analysis Model (HDSAM) version 2.06 [DOE 2009a]. This off-board cost was converted to the refueling portion of the ownership cost by using an assumed fuel economy of the hydrogen FCV. The onboard storage system cost was converted to the fuel system purchased cost portion of the ownership cost by applying the appropriate Retail Price Equivalent (RPE) multiplier (MSRP relative to the cost of manufacturing) as well as other assumptions (e.g., Annual Discount Factor and Annual Mileage) to convert the purchased cost to an equivalent \$/mile estimate.

The RPE multiplier actually consists of two markups to go from automotive OEM "Factory Cost" to MSRP - the hydrogen storage system manufacturer markup and the dealer markup. The RPE multiplier ranges between 1.46 and 2.00: Vyas et al. [2000] suggest that the RPE multiplier should be 2.00, while Rogozhin et al. [2009] develops an automobile industry average weighted RPE multiplier of 1.46 based on 2007 data, and an RPE multiplier of 1.70 based on McKinsey data for the automobile manufacturing industry. We assumed an RPE multiplier of 1.74 based on a recent DOE Report to Congress [DOE 2008]. 
Table 4: Life cycle assumptions for pipeline delivery scenario

\begin{tabular}{|l|c|l|}
\hline \multicolumn{1}{|c|}{ Process/Process Fuels } & $\begin{array}{c}\text { Parameter and } \\
\text { Value }\end{array}$ & \multicolumn{1}{c|}{ Basis/Comment } \\
\hline Electricity production & $\begin{array}{c}\text { Thermal efficiency } \\
32.2 \%\end{array}$ & $\begin{array}{l}\text { EIA projected U.S. grid for 2015, inclusive of } \\
8 \% \text { transmission loss from power plant to user } \\
\text { site }\end{array}$ \\
\hline North American NG & $\begin{array}{c}\text { Production efficiency } \\
93.5 \%\end{array}$ & GREET data \\
\hline $\mathbf{H}_{2}$ production by SMR & $\begin{array}{c}\text { Process efficiency } \\
71 \%\end{array}$ & Data for industrial SMR \\
\hline Thermal energy from NG & $\begin{array}{c}\text { Heat transfer } \\
\text { efficiency } \\
85 \%\end{array}$ & $\begin{array}{l}\text { FCHtool model, consistent with large scale } \\
\text { boilers }\end{array}$ \\
\hline $\mathbf{H}_{\mathbf{2}}$ delivery by pipeline & $\begin{array}{c}\text { Pressure drop } \\
50 \text { bar }\end{array}$ & H2A 50\% market share scenario \\
\hline $\mathbf{H}_{2}$ compression & $\begin{array}{c}\text { Isentropic efficiency } \\
88 \% \text { (central plant) } \\
65 \% \text { (fueling station) }\end{array}$ & HDSAM data \\
\hline Precooling for fast fills & $25^{\circ} \mathrm{C}$ to $-40^{\circ} \mathrm{C}$ & $\begin{array}{l}\text { Only for 700-bar tanks, no precooling assumed } \\
\text { for 350-bar tanks }\end{array}$ \\
\hline GHG emissions & Range & Emission factors data from GREET \\
\hline
\end{tabular}

\section{Performance Results}

We evaluated the well-to-tank (WTT) energy efficiency of and GHG emissions from the fuel cycle necessary to support refueling the compressed hydrogen systems for automotive applications. The results discussed here are for hydrogen production by steam methane reforming (SMR) at a central plant and pipeline delivery of the hydrogen to the refueling stations.

The analysis assumed that SMR produces fuel quality hydrogen at 20 bar (290 psia), after which the gas is compressed to the final pressure in three steps. In the first step, hydrogen is compressed at the central station for pipeline delivery to the fueling station. We assumed that a three-stage, intercooled, centrifugal compressor is used at the production facility to compress hydrogen from 20 bar to 70 bar (1,030 psia) and that a pressure drop of 50 bar occurs in the pipeline, so that the hydrogen delivered to the fueling station is at 20 bar. In the second step, a five-stage centrifugal compressor is used at the fueling station to compress the hydrogen from 20 bar to 180 bar (2650 psia). In the third stage, also carried out at the fueling station, the hydrogen is compressed from 180 bar to 438 bar (6,440 psia) for the 350-bar tank and to 875 bar (12,860 psia) for the 700-bar tank. The analysis further assumed that the large compressors at the central production facility have $88 \%$ isentropic efficiency, 97\% mechanical efficiency (i.e., 3\% bearing loss) and 90\% motor efficiency. At the fueling station, the smaller compressors are assumed to have a lower isentropic efficiency of $65 \%$ but the same mechanical and motor efficiencies. 
Hydrogen storage at 350 bar requires $2.9 \mathrm{kWh} / \mathrm{kg}-\mathrm{H}_{2}$ electric energy for compression total for the three steps mentioned above. The electric energy requirement increases to $3.7 \mathrm{kWh} / \mathrm{kg}-\mathrm{H}_{2}$ for the 700-bar storage option. ${ }^{8}$ Assuming that electricity is generated using the projected 2015 grid mix, the WTT efficiency is 56.5\% for the 350-bar storage option and 54.2\% for the 700-bar storage option. Both of these efficiencies are within a few percentage points of the $60 \% \mathrm{DOE}$ target.

The estimated life cycle GHG emissions are $14.2 \mathrm{~kg} \mathrm{CO}$ equiv/kg- $\mathrm{H}_{2}$ for the 350-bar hydrogen storage option. Hydrogen production by SMR accounts for $84 \%$ of this total, storage (i.e., compressors at the fueling station) contributes $12 \%$, and the remaining $4 \%$ is due to pipeline delivery of gaseous hydrogen. The total GHG emissions increase to $14.8 \mathrm{~kg} \mathrm{CO}$ equiv $/ \mathrm{kg}-\mathrm{H}_{2}$ (production 80\%, storage 16\%, and pipeline delivery 4\%) for the 700-bar hydrogen storage option.

\section{Cost Results}

The HDSAM result for the cost of hydrogen delivery via compressed gas pipeline is $\$ 2.72 / \mathrm{kg} \mathrm{H}_{2}$ for refueling a 350-bar storage system and $\$ 2.83 / \mathrm{kg} \mathrm{H}_{2}$ for refueling a 700 bar storage system. These costs assume 30\% market penetration in a prototypical urban area (Indianapolis, IN) including geologic terminal storage and $1,000 \mathrm{~kg} \mathrm{H}_{2} /$ day fueling station capacity with cascade storage. ${ }^{9}$ For consistency with the assessment of other hydrogen storage options, hydrogen production costs (i.e., central plant costs) were assumed to be $\$ 1.50 / \mathrm{kg} \mathrm{H}_{2}$, which is also consistent with H2A Production Model results for the lower-cost production options (e.g., central production from natural gas-based SMR) [DOE 2009b]. Therefore, the total refueling cost estimate for a 350-bar compressed hydrogen storage system was estimated to be $\$ 4.22 / \mathrm{kg} \mathrm{H_{2 }}$ (\$4.22/gallon gasoline equivalent [gge]), and \$4.33/kg $\mathrm{H}_{2}$ (\$4.33/gge) for a 700-bar system.

Combining these off-board costs with the on-board system base case cost projections of $\$ 15.4 / \mathrm{kWh}$ and $\$ 18.7 / \mathrm{kWh} \mathrm{H}_{2}$, and using the simplified economic assumptions presented in Table 5, resulted in a fuel system ownership cost estimate of $\$ 0.13 /$ mile for 350-bar and $\$ 0.15 /$ mile for 700 -bar compressed hydrogen storage. About half of this cost is due to the purchased cost of the on-board storage system and half is due to the refueling or off-board cost. This compares to about $\$ 0.10 /$ mile for a conventional gasoline internal combustion engine vehicle (ICEV) when gasoline is $\$ 3.00 /$ gal (untaxed). The 350-bar fuel system ownership costs would be comparable to a gasoline ICEV with gasoline at $\$ 4.00 /$ gal and the 700 -bar fuel system ownership costs would be comparable with those of gasoline at $\$ 4.50 /$ gal. An implicit assumption in this ownership cost comparison is that each fuel system/vehicle has the same operating lifetime, that the hydrogen FCV achieves two times the fuel economy of a similarly sized ICEV, and that the FCV performs at least as well as an ICEV in all other aspects of operation.

\footnotetext{
${ }^{8}$ These hydrogen storage electricity consumption results are comparable to the results in HDSAM version 2.06 (i.e., 2.9 and $3.8 \mathrm{kWh} / \mathrm{kg}-\mathrm{H}_{2}$ for 350 and 700 -bar storage, respectively).

${ }^{9}$ Using boost compression instead of cascade storage results in slightly higher $\left(\$ 3.17 / \mathrm{kg} \mathrm{H}_{2}\right.$ for 700 bar) costs but may be more practical in near-term systems due to the lack of high-pressure, stationary tank availability.
} 
Table 5: Fuel system ownership cost assumptions and results

\begin{tabular}{|c|c|c|c|c|}
\hline $\begin{array}{l}\text { Fuel System } \\
\text { Ownership Cost }\end{array}$ & $\begin{array}{l}\text { Gasoline } \\
\text { ICEV }\end{array}$ & $\begin{array}{l}\text { 350-bar } \\
\mathrm{FCV}^{10}\end{array}$ & $\begin{array}{l}\text { 700-bar } \\
\text { FCV }^{11}\end{array}$ & Basis/Comment \\
\hline $\begin{array}{l}\text { Annual Discount } \\
\text { Factor on Capital }\end{array}$ & \multicolumn{3}{|c|}{$15 \%$} & Input assumption \\
\hline $\begin{array}{l}\text { Manufacturer + } \\
\text { Dealer Markup }\end{array}$ & \multicolumn{3}{|c|}{1.74} & $\begin{array}{l}\text { Assumed mark-up from factory cost } \\
\text { estimates [DOT 2007] }\end{array}$ \\
\hline $\begin{array}{l}\text { Annual Mileage, } \\
\text { mi/yr }\end{array}$ & \multicolumn{3}{|c|}{12,000} & H2A assumption \\
\hline $\begin{array}{l}\text { Vehicle Energy } \\
\text { Efficiency Ratio }\end{array}$ & 1.0 & \multicolumn{2}{|c|}{2.0} & FCV: Based on ANL drive-cycle modeling \\
\hline $\begin{array}{l}\text { Fuel Economy, } \\
\text { mpgge }\end{array}$ & 31 & \multicolumn{2}{|c|}{62} & $\begin{array}{l}\text { ICEV: Car combined CAFE sales } \\
\text { weighted FE estimate for } 2007 \text { [DOT } \\
\text { 2007] }\end{array}$ \\
\hline $\begin{array}{l}\mathrm{H}_{2} \text { Storage } \\
\text { Requirement, } \mathrm{kg} \mathrm{H}_{2}\end{array}$ & NA & \multicolumn{2}{|c|}{5.6} & $\begin{array}{l}\text { FCV: Design assumption based on ANL } \\
\text { drive-cycle modeling }\end{array}$ \\
\hline $\begin{array}{l}\mathrm{H}_{2} \text { Storage System } \\
\text { Factory Cost, \$/kWh }\end{array}$ & NA & 15.4 & 18.7 & $\begin{array}{l}\text { FCV: } \mathrm{H}_{2} \text { storage cost from On-board } \\
\text { Assessment Base Case }\end{array}$ \\
\hline $\begin{array}{l}\text { Fuel Price } \\
\text { (untaxed), \$/gge }\end{array}$ & 3.00 & 4.22 & 4.33 & $\begin{array}{l}\text { FCV: Equivalent } \mathrm{H}_{2} \text { price from Off-board } \\
\text { Assessment Base Case }\end{array}$ \\
\hline $\begin{array}{l}\text { Ownership Cost } \\
\text { Result, \$/mile }\end{array}$ & 0.10 & 0.13 & 0.15 & \\
\hline
\end{tabular}

\section{Summary and Conclusions}

A technical assessment of compressed hydrogen storage tank systems for automotive applications has been conducted. The assessment criteria included the prospects of meeting the near-term and ultimate DOE targets for on-board hydrogen storage systems for light-duty vehicles with a Type IV tank design. We found that substantial carbon fiber composite material cost reductions and/or performance improvements (e.g., much higher translation strength efficiency) are needed in order to meet the DOE on-board cost and weight targets. Higher pressures, lower temperatures and/or sorbents are needed to meet volumetric targets. While fuel costs are projected to be much higher than the DOE target range, fuel system ownership costs are not projected to be significantly higher than those for a gasoline ICEV because of the factor of 2 higher fuel economy of the hydrogen FCV.

The main conclusions from this assessment are summarized Table 6 and discussed below. Additionally, the results for the Type III and Type IV single- and dual-tank systems are summarized in Table 7.

\footnotetext{
${ }^{10}$ Assumes 438 bar cascade storage and dispensing for 350-bar on-board storage system.

${ }^{11}$ Assumes 875 bar cascade storage and dispensing for 700-bar on-board storage system.
} 
Table 6: Summary results of the assessment for Type IV single-tank compressed hydrogen storage systems

\begin{tabular}{|c|c|c|c|c|c|c|}
\hline $\begin{array}{l}\text { Performance and Cost } \\
\text { Metric }\end{array}$ & Units & 350-bar & 700-bar & $\begin{array}{l}2010 \\
\text { Targets }\end{array}$ & $\begin{array}{c}2015 \\
\text { Targets }\end{array}$ & $\begin{array}{l}\text { Ultimate } \\
\text { Targets }\end{array}$ \\
\hline $\begin{array}{l}\text { Usable Storage Capacity } \\
\text { (Nominal) }\end{array}$ & $\mathrm{kg}-\mathrm{H}_{2}$ & 5.6 & 5.6 & N/A & N/A & $N / A$ \\
\hline $\begin{array}{l}\text { Total Storage Capacity } \\
\text { (Maximum) }\end{array}$ & $\mathrm{kg}-\mathrm{H}_{2}$ & 6.0 & 5.8 & N/A & $\mathrm{N} / \mathrm{A}$ & N/A \\
\hline $\begin{array}{l}\text { System Gravimetric } \\
\text { Capacity }\end{array}$ & wt\% & 5.5 & 4.2 & 4.5 & 5.5 & 7.5 \\
\hline $\begin{array}{l}\text { System Volumetric } \\
\text { Capacity }\end{array}$ & $\begin{array}{c}\mathrm{kg}- \\
\mathrm{H}_{2} / \mathrm{m}^{3}\end{array}$ & 17.6 & 26.3 & 28 & 40 & 70 \\
\hline Storage System Cost & $\$ / \mathrm{kWh}$ & 15.4 & 18.7 & 4 & 2 & TBD \\
\hline Fuel Cost & $\$ / g g e$ & 4.22 & 4.33 & $2-3$ & $2-3$ & $2-3$ \\
\hline Ownership Cost & $\$ /$ mile & 0.13 & 0.15 & N/A & $\mathrm{N} / \mathrm{A}$ & $\mathrm{N} / \mathrm{A}$ \\
\hline WTT Efficiency & $\%$ & 56.5 & 54.2 & 60 & 60 & 60 \\
\hline GHG Emissions $\left(\mathrm{CO}_{2} \mathrm{eq}\right)$ & $\begin{array}{c}\mathrm{kg} / \mathrm{kg}- \\
\mathrm{H}_{2}\end{array}$ & 14.2 & 14.8 & $\mathrm{~N} / \mathrm{A}$ & $\mathrm{N} / \mathrm{A}$ & N/A \\
\hline
\end{tabular}

\section{Gravimetric Capacity}

The 350-bar compressed tank system capable of storing $5.6 \mathrm{~kg}$ of recoverable hydrogen has a nominal usable gravimetric capacity of $5.5 \mathrm{wt} \%$. The nominal capacity increases to $5.8 \mathrm{wt} \%$ if the "empty" pressure is reduced to 3 bar and $5.7 \mathrm{wt} \%$ if the CF translation strength efficiency improves to $90 \%$ with advances in filament winding technology. Thus, the 350-bar compressed option easily exceeds the 2010 target of $4.5 \mathrm{wt} \%$ and meets the 2015 target of $5.5 \mathrm{wt} \%$ without any changes. It is unlikely to meet the ultimate target of $7.5 \mathrm{wt} \%$ even if the CF translation strength efficiency reaches the theoretical value of $100 \%$ and the glass fiber and foam end caps are removed (i.e., $6.9 \mathrm{wt} \%$ ).

The 700-bar compressed tank system capable of storing $5.6 \mathrm{~kg}$ of recoverable hydrogen has a nominal usable gravimetric capacity of $5.2 \mathrm{wt} \%$. The nominal capacity increases to $5.3 \mathrm{wt} \%$ if the "empty" pressure is reduced to 3 bar (45 psi), and to $5.6 \mathrm{wt} \%$ if the CF translation strength efficiency improves to $90 \%$ with advances in filament winding technology. Thus, the 700-bar compressed option also exceeds the 2010 target of $4.5 \mathrm{wt} \%$, but it can only meet the 2015 target of $5.5 \mathrm{wt} \%$ if the CF translation strength efficiency improves over the current state of the art. It is unlikely to meet the ultimate target of $7.5 \mathrm{wt} \%$ even if the CF translation strength efficiency reaches the theoretical value of $100 \%$ and the glass fiber and foam end caps are removed (i.e., $6.5 \mathrm{wt} \%)$.

Either system, 350- or 700-bar, could improve its gravimetric capacity by using a higher strength carbon fiber composite, but this would likely increase the system cost, because T700S has the 
most attractive strength-to-cost ratio of the commercially available carbon fiber options currently being considered for this application.

\section{Volumetric Capacity}

The 350-bar compressed tank system has a nominal volumetric capacity of 17.6 g- $\mathrm{H}_{2} / \mathrm{L}$. The nominal capacity increases to $18.6 \mathrm{~g}-\mathrm{H}_{2} / \mathrm{L}$ if the "empty" pressure is reduced to 3 bar. Increasing the CF translation strength efficiency to $90 \%$ has very little effect on the volumetric capacity (i.e., 17.7 g- $\mathrm{H}_{2} / \mathrm{L}$ ). Thus, the 350-bar system falls far short of meeting even the 2010 target of $28 \mathrm{~g}$ $\mathrm{H}_{2} / \mathrm{L}$ with the credits and modifications considered in this assessment.

The 700-bar compressed tank system has a nominal volumetric capacity of $26.3 \mathrm{~g}-\mathrm{H}_{2} / \mathrm{L}$. The nominal capacity increases to $27.2 \mathrm{~g}-\mathrm{H}_{2} / \mathrm{L}$ if the "empty" pressure is reduced to 3 bar. Increasing the CF translation strength efficiency to $90 \%$ increases the volumetric capacity to $26.9 \mathrm{~g}-\mathrm{H}_{2} / \mathrm{L}$. Thus, the 700-bar system is close to meeting the 2010 target of $28 \mathrm{~g}-\mathrm{H}_{2} / \mathrm{L}$, but falls far short of meeting the 2015 target of 40 g- $\mathrm{H}_{2} / \mathrm{L}$ and the ultimate DOE target of 70 g- $\mathrm{H}_{2} / \mathrm{L}$ with the credits and modifications considered in this assessment.

\section{Storage System and Fuel Cost}

The high-volume manufactured cost of the base case 350-bar single tank, Type IV compressed tank system is $\$ 15.4 / \mathrm{kWh}$, and $\$ 18.7 / \mathrm{kWh}$ for the base case 700 -bar single tank, Type IV system. These manufactured system costs, based on assumptions considered most likely to be applicable (i.e., base cases), are 4 - 5 times more than the current DOE 2010 cost target of $\$ 4 / \mathrm{kWh}$. According to the multi-variable sensitivity analysis results, the factory cost will likely range between $\$ 10.6$ and $\$ 19.7 / \mathrm{kWh}$ for the 350-bar system and between $\$ 13.5$ and $\$ 27.2 / \mathrm{kWh}$ for the 700-bar system. ${ }^{12}$ Type III tanks are projected to add $\$ 1.2$ and $\$ 2.2 / \mathrm{kWh}$ to the system cost of 350-bar and 700-bar systems, respectively, while dual tank systems are projected to add less than $\$ 0.5 / \mathrm{kWh}$ to system costs. Substantial carbon fiber composite material cost reductions and/or performance improvements, and BOP cost reductions are needed in order to meet DOE cost targets. Balance of system costs (i.e., non-carbon fiber composite costs) alone, which make up a small fraction of the total system cost, are around 75\% of the 2010 cost target (i.e., approximately $\$ 3 / \mathrm{kWh})$.

The fuel cost for the reference SMR production and compressed hydrogen delivery scenario is $\$ 4.22$ and $\$ 4.33 /$ gge for the 350-bar and 700-bar cases, respectively. This is approximately $40 \%$ $120 \%$ higher than the current DOE target of \$2-3/gge. When on-board and off-board costs are combined, the 350-bar compressed system has potential to have similar ownership costs as a gasoline ICEV, albeit about $20 \%$ ( $2 \$ / \mathrm{mi}$ or $\$ 240 / \mathrm{yr}$ ) higher when gasoline is $\$ 3.00 / \mathrm{gal}$. The 700 -bar system is projected to have $50 \%$ higher ownership cost compared to an ICEV when gasoline is $\$ 3.00 / \mathrm{gal}$.

\section{Efficiency and Greenhouse Gas Emissions}

Whereas efficiency is not a specified DOE target, the systems are required to be energy efficient.

\footnotetext{
${ }^{12}$ Range is defined here as the $95 \%$ confidence interval based on the data fit for the sensitivity analysis.
} 
A footnote in the DOE hydrogen target table requires the WTT efficiency for the off-board regenerable systems to be higher than $60 \%$. The compressed tank options almost meet this target. WTT efficiencies are projected to be $56.5 \%$ and $54.2 \%$ for 350 -bar and 700 -bar refueling, respectively, assuming that electricity is generated using the projected 2015 grid mix. The corresponding estimated GHG emissions for hydrogen production by SMR and compressed hydrogen delivery are $14.2 \mathrm{~kg} / \mathrm{kg}-\mathrm{H}_{2}$ and $14.8 \mathrm{~kg} / \mathrm{kg}-\mathrm{H}_{2}$ for the 350-bar and 700-bar base cases, respectively. 
Table 7: Summary results of the assessment for Type III and Type IV single and dual tank compressed hydrogen storage systems

\begin{tabular}{|c|c|c|c|c|c|c|c|c|c|c|c|c|}
\hline Performance and Cost Metric & Units & $\begin{array}{c}\mathrm{CH} 2 \\
350-\mathrm{T} 3 \\
\end{array}$ & $\begin{array}{c}\mathrm{CH} 2 \\
350-\mathrm{T} 3 \\
\end{array}$ & $\begin{array}{c}\mathrm{cH} 2 \\
350-\mathrm{T} 4 \\
\end{array}$ & $\begin{array}{c}\mathrm{cH} 2 \\
350-\mathrm{T} 4 \\
\end{array}$ & $\begin{array}{c}\mathrm{cH} 2 \\
700-\mathrm{T} 3 \\
\end{array}$ & $\begin{array}{c}\mathrm{cH} 2 \\
700-\mathrm{T} 3 \\
\end{array}$ & $\begin{array}{c}\mathrm{cH} 2 \\
700-\mathrm{T} 4\end{array}$ & $\begin{array}{c}\mathrm{cH} 2 \\
700-\mathrm{T} 4\end{array}$ & $\begin{array}{c}2010 \\
\text { Targets } \\
\end{array}$ & $\begin{array}{c}2015 \\
\text { Targets } \\
\end{array}$ & $\begin{array}{l}\text { Ultimate } \\
\text { Targets }\end{array}$ \\
\hline Tank & & 1-Tank & 2-Tank & 1-Tank & 2-Tank & 1-Tank & 2-Tank & 1-Tank & 2-Tank & & & \\
\hline Total Storage Capacity & $\mathrm{kg}-\mathrm{H}_{2}$ & 6.0 & 6.0 & 6.0 & 6.0 & 5.8 & 5.8 & 5.8 & 5.8 & & & \\
\hline Usable Storage Capacity & $\mathrm{kg}-\mathrm{H}_{2}$ & 5.6 & 5.6 & 5.6 & 5.6 & 5.6 & 5.6 & 5.6 & 5.6 & & & \\
\hline System Gravimetric Capacity & wt $\%$ & 4.2 & 4.0 & 5.5 & 5.0 & 3.6 & 3.5 & 5.2 & 4.8 & 4.5 & 5.5 & 7.5 \\
\hline System Volumetric Capacity & $\mathrm{kg}-\mathrm{H}_{2} / \mathrm{m}^{3}$ & 17.4 & 17.2 & 17.6 & 17.2 & 25.0 & 24.7 & 26.3 & 25.6 & 28 & 40 & 70 \\
\hline Storage System Cost & $\$ / \mathrm{kWh}$ & 16.8 & 16.9 & 15.4 & 15.8 & 21.2 & 21.4 & 18.7 & 19.2 & 4 & 2 & TBD \\
\hline Fuel Cost & $\$ / g g e$ & 4.2 & 4.2 & 4.2 & 4.2 & 4.3 & 4.3 & 4.3 & 4.3 & $2-3$ & $2-3$ & $2-3$ \\
\hline Cycle Life (1/4 tank to Full) & Cycles & 5500 & 5500 & NA & NA & 5500 & 5500 & NA & NA & 1000 & 1500 & 1500 \\
\hline Minimum Delivery Pressure, FC/ICE & atm & 4 & 4 & 4 & 4 & 4 & 4 & 4 & 4 & $4 / 35$ & $3 / 35$ & $3 / 35$ \\
\hline WTT Efficiency & $\%$ & 56.5 & 56.5 & 56.5 & 56.5 & 54.2 & 54.2 & 54.2 & 54.2 & 60 & 60 & 60 \\
\hline GHG Emissions $\left(\mathrm{CO}_{2}\right.$ eq $)$ & $\mathrm{kg} / \mathrm{kg}-\mathrm{H}_{2}$ & 14.2 & 14.2 & 14.2 & 14.2 & 14.8 & 14.8 & 14.8 & 14.8 & & & \\
\hline Ownership Cost & $\$ /$ mile & 0.13 & 0.13 & 0.13 & 0.13 & 0.15 & 0.15 & 0.14 & 0.14 & & & \\
\hline
\end{tabular}




\section{References}

1. Abdallah, M., “Low Cost Carbon Fiber (LCCF) Development Program,” Hexcel, Phase I Final Report to DOE ORNL, August 2004.

2. Ahluwalia, R. K., Hua, T. Q., and Peng, J. K., "Fuel Cycle Efficiencies of Different Automotive On-Board Hydrogen Storage Options,” International Journal of Hydrogen Energy, 32(15), 3592-3602, 2007.

3. Ahluwalia, R. K., Wang, X., Rousseau, A., and Kumar, R., "Fuel Economy of Hybrid Fuel Cell Vehicles,” Journal of Power Sources, 152, 233-244, 2005.

4. Ahluwalia, R. K., Wang, X., Rousseau, A., and Kumar, R., "Fuel Economy of Hydrogen Fuel Cell Vehicles,” Journal of Power Sources, 130, 192-201, 2004.

5. Du Vall, F., "Cost Comparisons of Wet Filament Winding Versus Prepreg Filament Winding for Type II and Type-IV CNG Cylinders," SAMPE Journal, Vol. 37, No. 1, p. 39-42, January/February 2001.

6. Hua, T. Q., Peng, J. K., and Ahluwalia, R. K., "Performance Assessment of Compressed Hydrogen Storage Systems,” Argonne National Laboratory, August 2010.

7. Kromer, M, Lasher, S, Mckenney, K, Law, K, and Sinha, J, "H2 Storage using Compressed Gas: On-board System and Ownership Cost Update for 350 and 700-bar,” TIAX LLC, Final Report to DOE, August 2010.

8. Lee, S., Ed., Handbook of Composite Reinforcements, Wiley-VCH, 1993.

9. Liu, C., Quantum, Personal Communication, 2009.

10. Newhouse, N. L., Lincoln Composites, Personal Communication, 2010.

11. NREL, 2009 Composite Data Products, http://www.nrel.gov/hydrogen/proj_learning_demo.html

12. SAE International, “Surface Vehicle Information Report,” SAE J2579, 2009.

13. U.S. Department of Energy (DOE), 2009a: Hydrogen Delivery Scenario Analysis Model (HDSAM), http://www.hydrogen.energy.gov/h2a delivery.html

14. U.S. Department of Energy (DOE), 2009b: Hydrogen Production Model (H2A), http://www.hydrogen.energy.gov/h2a_production.html

15. U.S. Department of Energy (DOE), "Effects of a Transition to a Hydrogen Economy on Employment in the United States," Report to Congress, July 2008.

16. U.S. Department of Transportation (DOT), NHTSA, "Summary of Fuel Economy Performance," Washington, DC, March 2007.

17. Vasiliev, V. V. and Morozov, E. V., Mechanics and Analysis of Composite Materials. New York, NY: Elsevier, 2001.

18. Wang, M. Q., “GREET 1.7 - Transportation Fuel-Cycle Model, Argonne National Laboratory,” Argonne, IL, December 2005.

19. Vyas, A., Santini, D., and Cuenca, R., "Comparison of Indirect Cost Multipliers for Vehicle Manufacturing,” Center for Transportation Research, Energy Systems Division, Argonne National Laboratory, April 2000.

20. Rogozhin, A., Gallaher, M., and McManus, W., “Automobile Industry Retail Price Equivalent and Indirect Cost Multipliers,” report by RTI International for EPA, EPA-420-R09-003, February 2009. 


\section{APPENDIX A \\ Performance Assessment of Compressed Hydrogen Storage Systems}




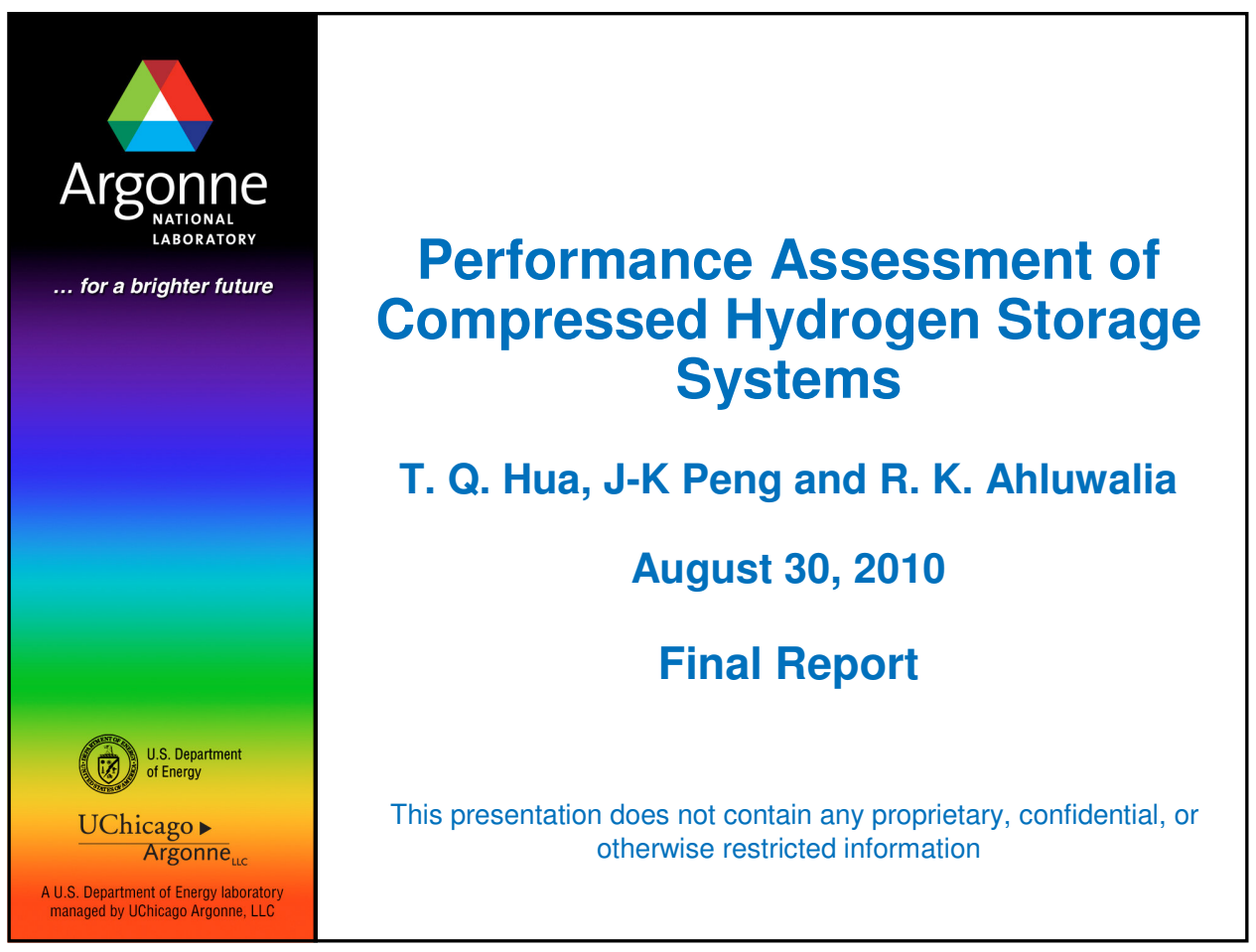

\section{Scope of Work}

- Gravimetric and volumetric capacities for compressed $\mathrm{H}_{2}$ storage options

- Type III and Type IV Tanks

- Single and dual tank designs

- Comparison with "Learning Demos" data

- Electricity requirement to compress $\mathrm{H}_{2}$ for on-board storage at 350 and 700 bar

Well-to-Tank efficiency and greenhouse gas emissions 


\section{Carbon Fiber Netting Analysis}

- Benedict-Webb-Rubin equation of state to calculate amount of stored $\mathrm{H}_{2}$ for $5.6 \mathrm{~kg}$ recoverable $\mathrm{H}_{2}$ and 20-bar minimum pressure

- Carbon fiber translation efficiency

- $82.5 \%$ for $350{\text { bar } \mathrm{cH}_{2}}$

- $80 \%$ for 700 bar

- 2.25 safety factor

- 5-mm HDPE liner, 1-mm glass fiber, and 10$\mathrm{mm}$ foam end caps (Type IV tanks)

- Construct optimal dome shape with geodesic winding pattern (i.e., along isotensoids)

- Geodesic and hoop windings in straight cylindrical section

- Iterate for tank diameter, CF thickness (nonuniform in end domes), given L/D

- Commercial data for BOP components
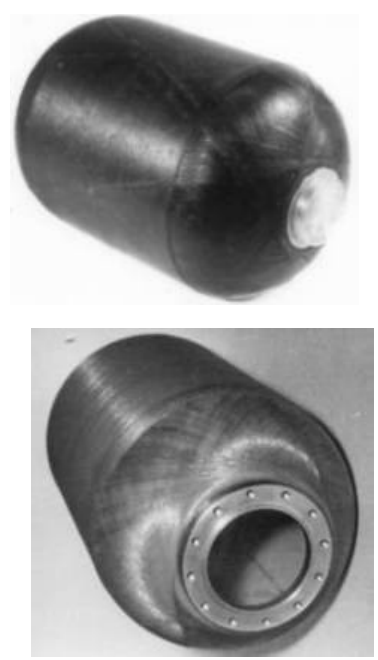

Ref: http://www.adoptech.com/pressure-vessels/main.htm

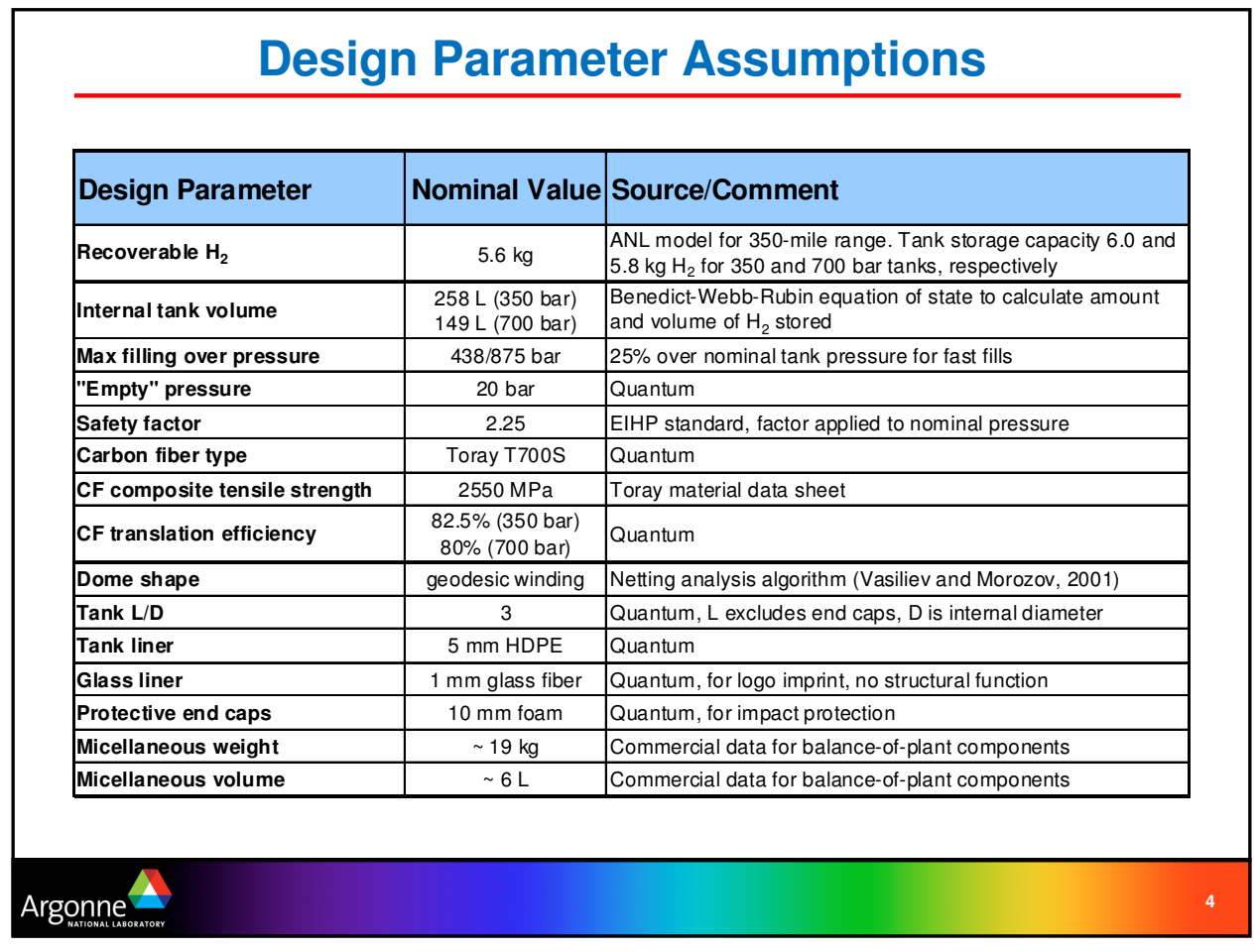




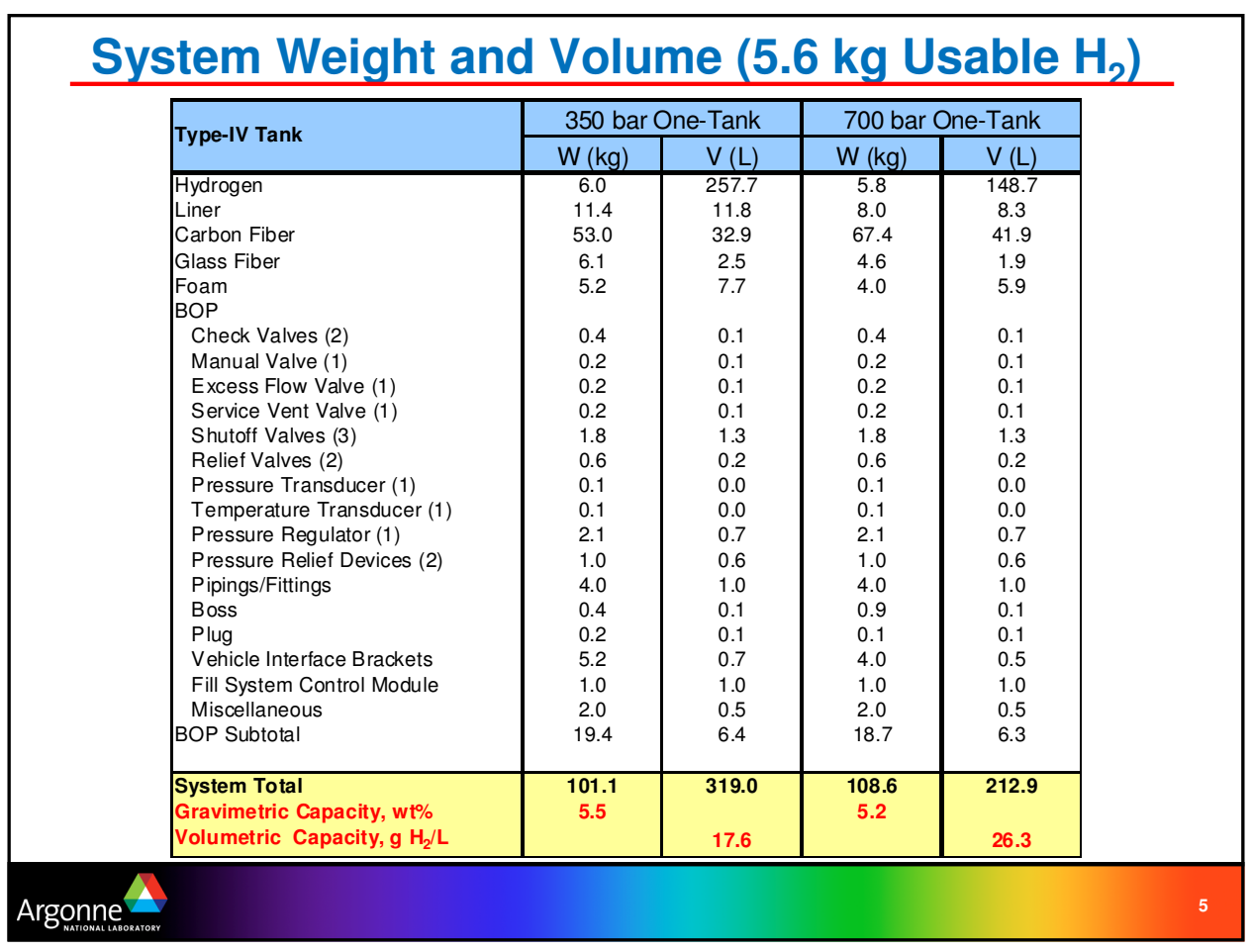

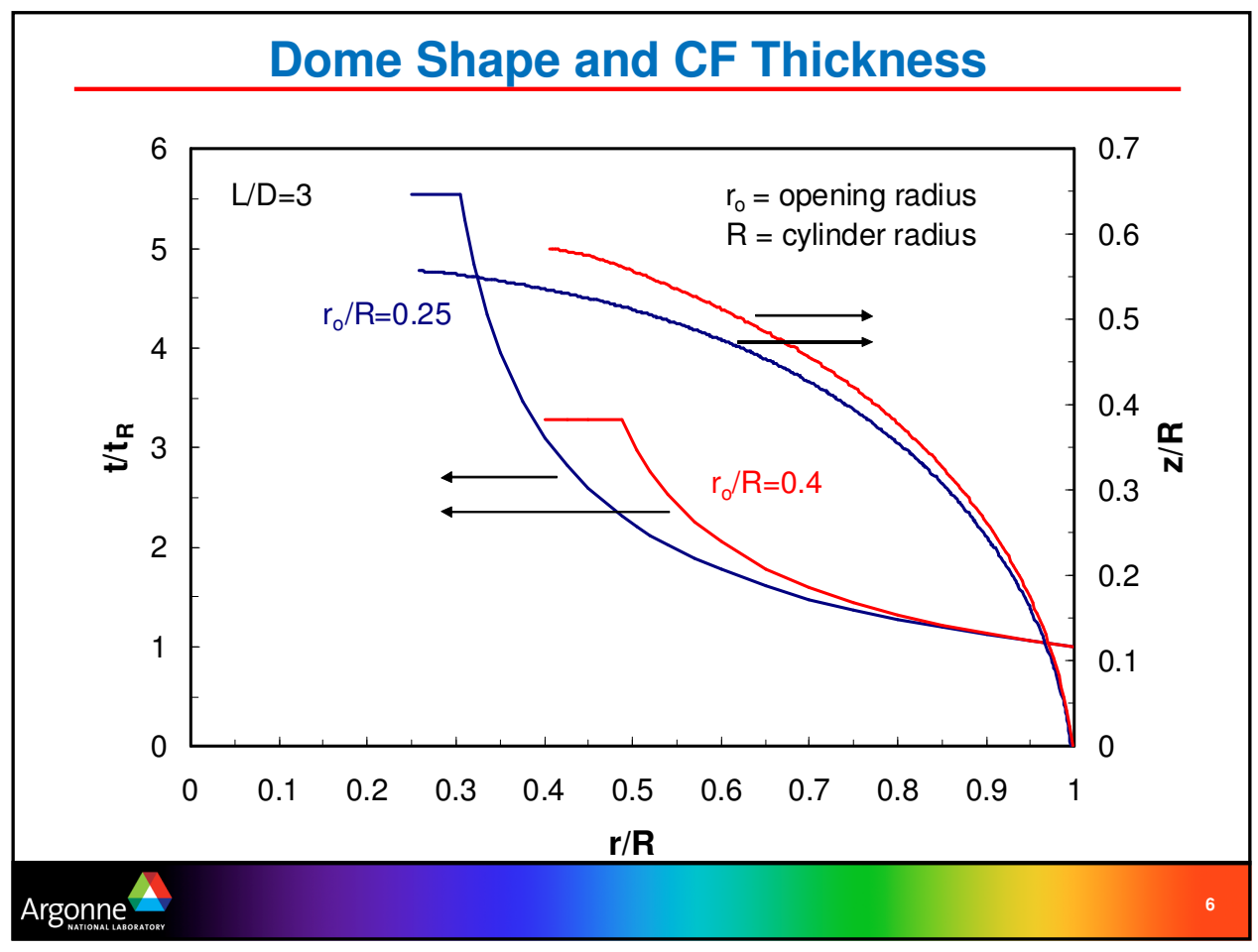



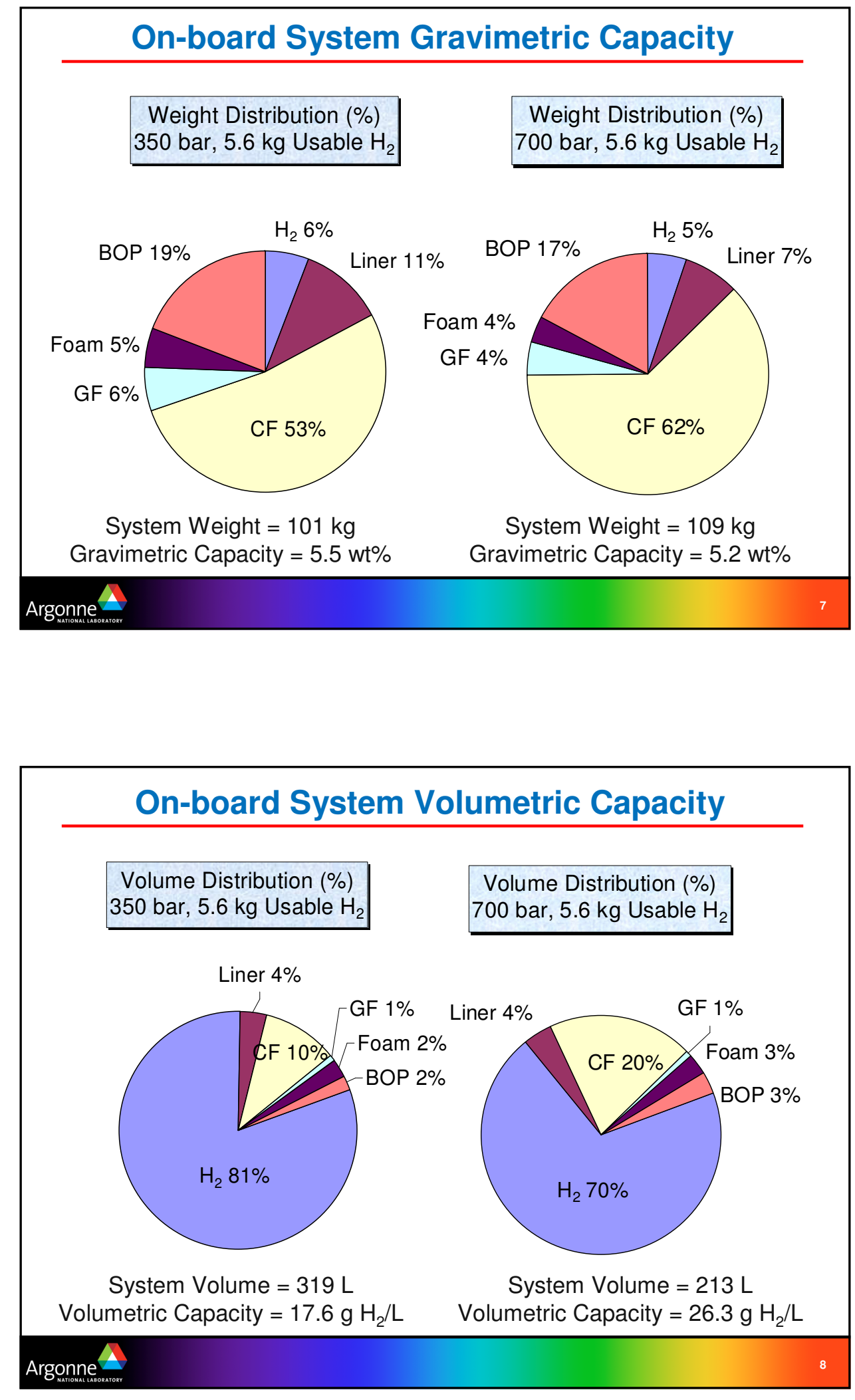


\section{Parametric Analysis of System Capacities}

- Improvement in carbon fiber translation efficiency or reducing minimum delivery pressure increases system capacities

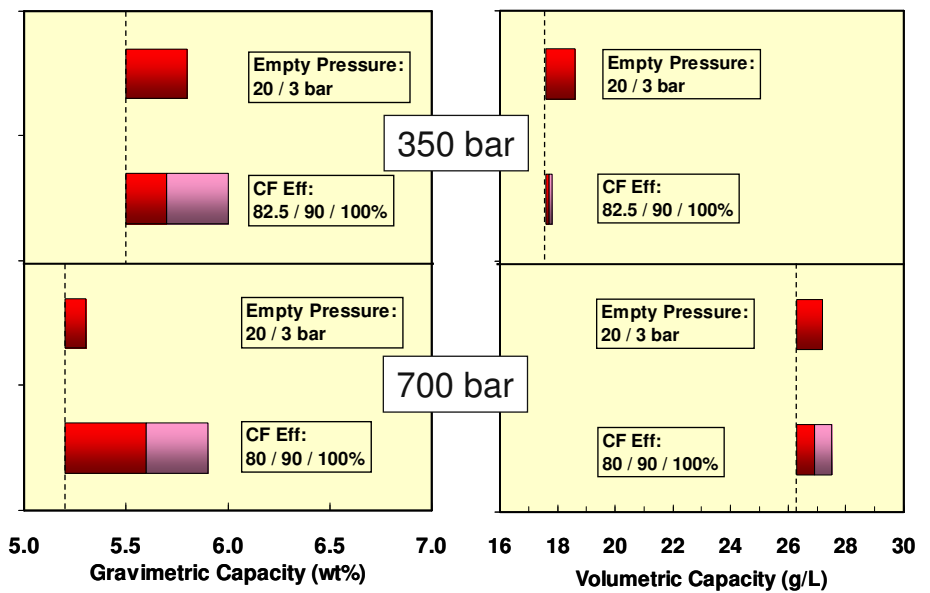

\section{$\mathrm{H}_{2}$ Delivery by Pipeline}

Pipeline delivery for $50 \%$ market share scenario

- $\mathrm{H}_{2}$ produced by SMR central plant at 20 bar, compressed to 70 bar for pipeline delivery to forecourt (50 bar pressure drop through pipeline)

- At the forecourt, $\mathrm{H}_{2}$ is compressed to 180 bar in 5 stages, then to 438 bar in 2 stages or 875 bar in 4 stages

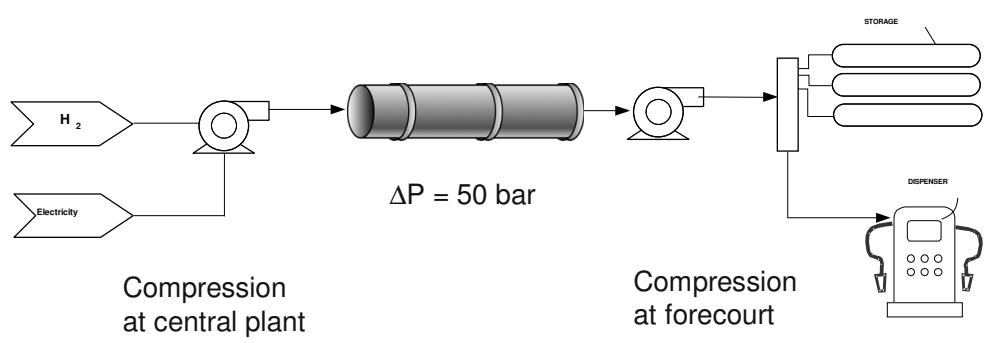




\section{Assessment of Type III Tank Systems}

Al 6061-T6 liner subjected to autofrettage to improve liner fatigue life. Autofrettage process produces residual compressive stress in liner and residual tensile stress in $\mathrm{CF}$

- Liner supports $10-15 \%$ of pressure load, thereby reducing the amount of CF requirement

- Liner thickness determined to meet 5500 pressure cycles at $125 \%$ nominal working pressure (SAE J2579)

- SN curve for Al 6061-T6

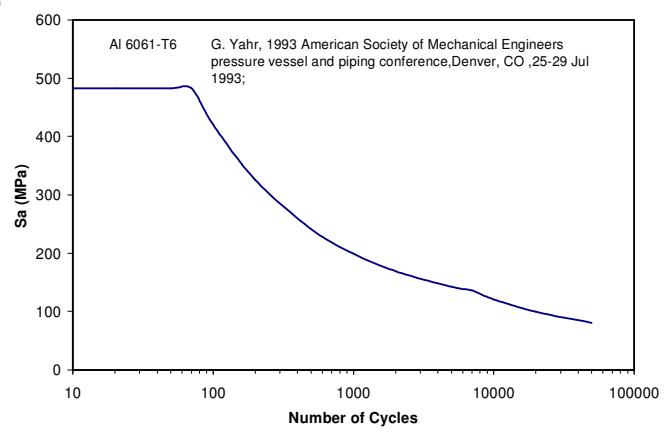

\section{Assessment of Dual Tank Systems}

Dual tank system offers additional packaging flexibility compared to single tank system

- Assume dual tank system design utilizes a single balance-of-plant (redundant BOPs are typically employed in current CNG buses)

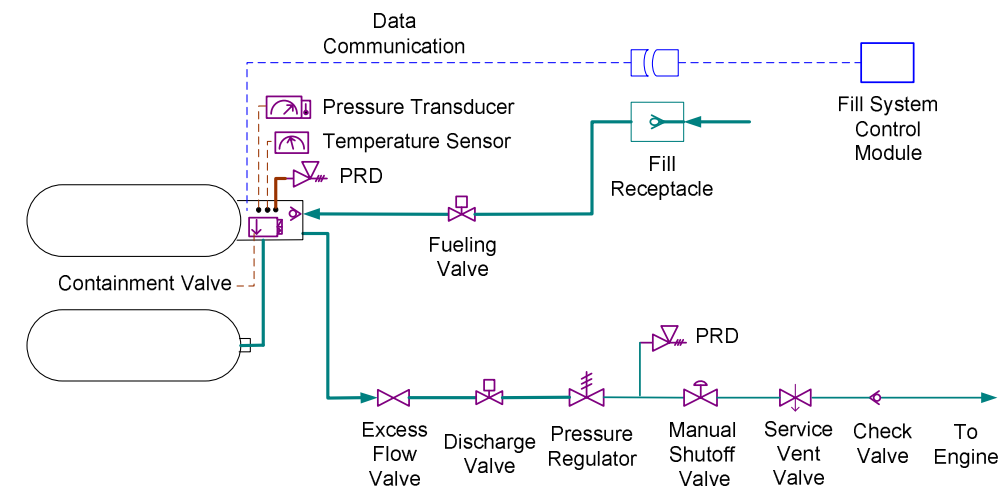



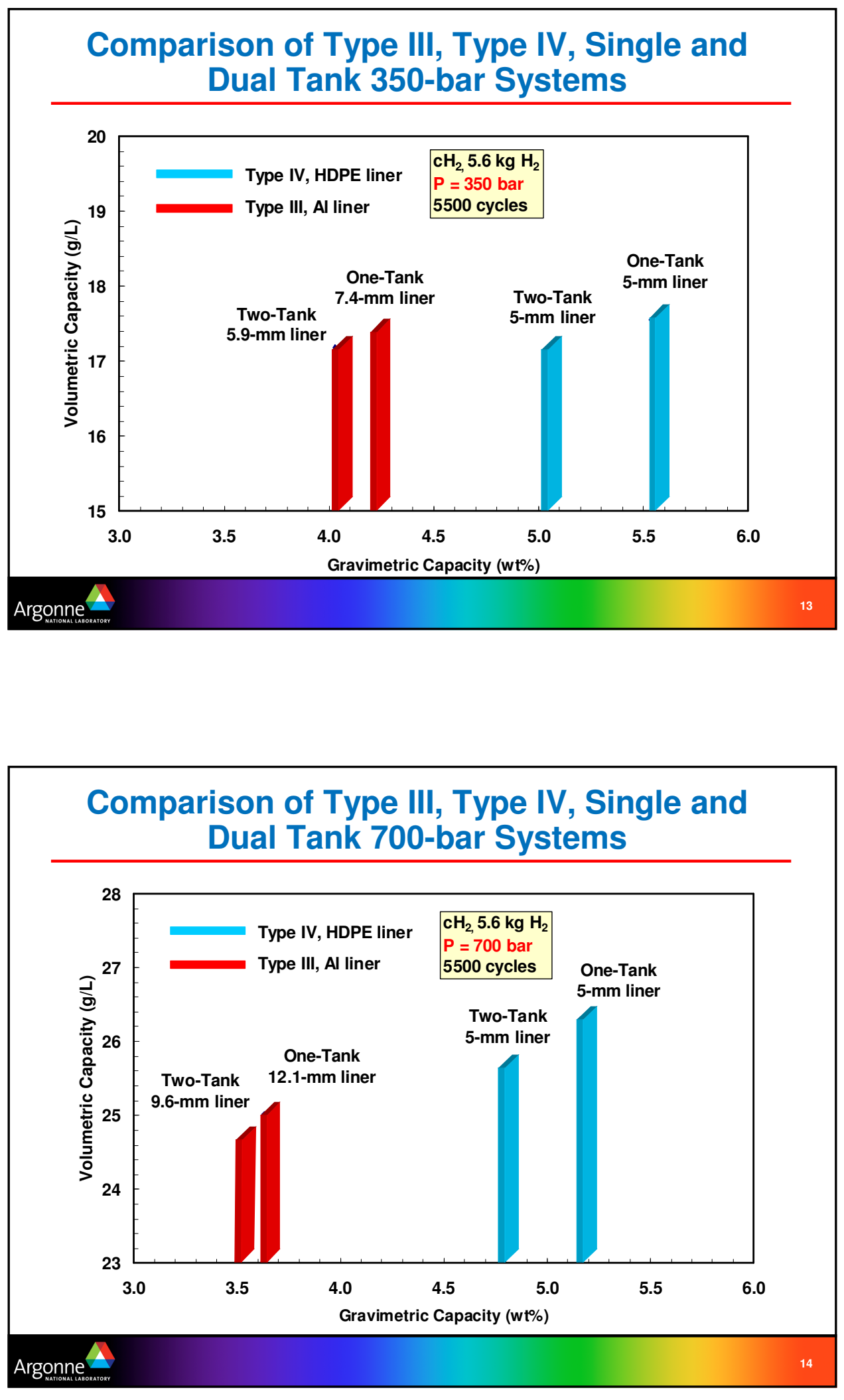


\section{Comparison of ANL Analysis with "Learning Demos"}

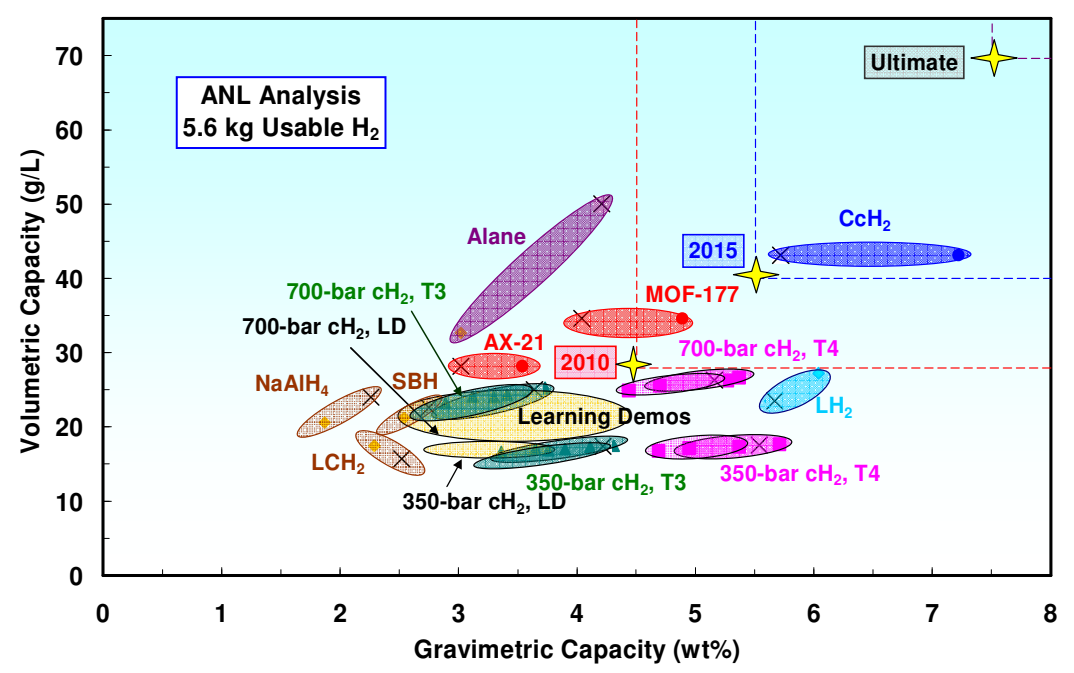

\section{Life Cycle Assumptions for Pipeline Delivery Scenario}

\begin{tabular}{|c|c|c|}
\hline Process/Process Fuels & Nominal Value & Source/Comment \\
\hline Electricity production & $\begin{array}{l}32.2 \% \text { thermal } \\
\text { efficiency }\end{array}$ & $\begin{array}{l}\text { EIA projected U.S. grid for } 2015 \text {, inclusive of } 8 \% \\
\text { transmission loss from power plant to user site }\end{array}$ \\
\hline $\begin{array}{l}\text { North American natural gas } \\
\text { production }\end{array}$ & 93.5\% efficiency & GREET data \\
\hline $\mathrm{H}_{2}$ production by SMR & $71 \%$ efficiency & Data for industrial SMR \\
\hline Thermal energy by NG & $\begin{array}{c}85 \% \text { heat transfer } \\
\text { efficiency }\end{array}$ & FCHtool model, consistent with large scale boilers \\
\hline $\mathrm{H}_{2}$ delivery by pipeline & 50 bar pressure drop & $\mathrm{H} 2 \mathrm{~A} 50 \%$ market share scenario \\
\hline $\begin{array}{l}\mathrm{H}_{2} \text { compression isentropic } \\
\text { efficiency }\end{array}$ & $\begin{array}{l}88 \% \text { (central plant) } \\
65 \% \text { (forecourt) }\end{array}$ & HDSAM data \\
\hline Precooling for fast fills & $25^{\circ} \mathrm{C}$ to $-40^{\circ} \mathrm{C}$ & $\begin{array}{l}\text { Only for } 700 \text { bar tanks, no precooling assumed for } 350 \text { bar } \\
\text { tanks }\end{array}$ \\
\hline Greenhouse gas emissions & range & Emission factors data from GREET \\
\hline
\end{tabular}

* R. K. Ahluwalia, T. Q. Hua, and J-K Peng, International Journal of Hydrogen Energy 32 (2007) 


\section{Electricity Consumption and WTT Efficiency}

\begin{tabular}{|c|c|c|c|c|c|c|}
\hline \multicolumn{2}{|c|}{ Compression $^{(a)}$} & \multirow{2}{*}{$\begin{array}{c}\text { \# of } \\
\text { Stages }\end{array}$} & \multirow{2}{*}{$\begin{array}{l}\text { Isentropic } \\
\text { efficiency }\end{array}$} & \multirow{2}{*}{$\begin{array}{l}\text { Electricity } \\
(\mathrm{kWh} / \mathrm{kg})\end{array}$} & \multirow{2}{*}{$\begin{array}{c}\text { WTT } \\
\text { efficiency }^{(b)}\end{array}$} & \multirow{2}{*}{ Comments } \\
\hline $\mathrm{P}_{\mathrm{i}}$ (bar) & $P_{f}$ (bar) & & & & & \\
\hline 20 & 70 & 3 & $88 \%$ & 0.6 & & Central plant, $P=50$ bar \\
\hline 20 & 180 & 5 & $65 \%$ & 1.6 & - & Forecourt \\
\hline 180 & 438 & 2 & $65 \%$ & 0.7 & - & Forecourt \\
\hline 180 & 875 & 4 & $65 \%$ & 1.3 & - & Forecourt \\
\hline 20 & 438 & 7 & $65-88 \%$ & 2.9 & $56.5 \%$ & 350 bar on-board storage \\
\hline 20 & 875 & 9 & $65-88 \%$ & $3.7^{(\mathrm{c})}$ & $54.2 \%$ & 700 bar on-board storage \\
\hline
\end{tabular}

Notes:

a) Compressor mechanical efficiency $=97 \%$, motor efficiency $=90 \%$

b) $\mathrm{H}_{2}$ produced by SMR central plant, electricity source from U.S. grid 2015, inclusive of $8 \%$ transmission loss

c) Includes $0.14 \mathrm{kWh} / \mathrm{kg}$ for precooling from $25^{\circ} \mathrm{C}$ to $-40^{\circ} \mathrm{C}$

\section{Life Cycle Greenhouse Gas Emissions $(\mathrm{g} / \mathrm{kg} \mathrm{H}))$}

350-bar on-board storage

\begin{tabular}{|l|rrrrrrrrr|}
\hline & VOC & $\mathbf{C O}$ & $\mathbf{N O}_{\mathbf{x}}$ & $\mathbf{P M}_{10}$ & $\mathbf{S O}_{\mathbf{x}}$ & $\mathbf{C H}_{\mathbf{4}}$ & $\mathbf{N}_{\mathbf{2}} \mathbf{O}$ & $\mathbf{C O}_{2}$ & $\mathbf{G H G s}$ \\
\hline $\mathbf{H}_{2}$ Production & 1.25 & 2.93 & 5.90 & 1.71 & 2.07 & 24.23 & 0.05 & 11,370 & 11,941 \\
$\mathbf{H}_{\mathbf{2}}$ Storage & 0.15 & 0.45 & 1.75 & 2.10 & 3.83 & 2.31 & 0.02 & 1,653 & 1,714 \\
$\mathbf{H}_{\mathbf{2}}$ Distribution & 0.04 & 0.13 & 0.51 & 0.62 & 1.12 & 0.68 & 0.01 & 484 & 502 \\
\hline \hline Total: & 1.45 & 3.52 & 8.16 & 4.43 & 7.01 & 27.22 & 0.08 & 13,507 & 14,157 \\
\hline
\end{tabular}

700-bar on-board storage

\begin{tabular}{|l|rrrrrrrrr|}
\hline & VOC & $\mathbf{C O}$ & $\mathbf{N O}_{\mathbf{x}}$ & $\mathbf{P M}_{10}$ & $\mathbf{S O}_{\mathbf{x}}$ & $\mathbf{C H}_{\mathbf{4}}$ & $\mathbf{N}_{\mathbf{2}} \mathbf{O}$ & $\mathbf{C O}_{2}$ & $\mathbf{G H G s}$ \\
\hline $\mathbf{H}_{\mathbf{2}}$ Production & 1.25 & 2.93 & 5.90 & 1.71 & 2.07 & 24.23 & 0.05 & 11,370 & 11,941 \\
$\mathbf{H}_{\mathbf{2}}$ Storage & 0.20 & 0.59 & 2.26 & 2.73 & 4.97 & 3.00 & 0.03 & 2,145 & 2,223 \\
$\mathbf{H}_{\mathbf{2}}$ Distribution & 0.05 & 0.16 & 0.62 & 0.75 & 1.36 & 0.82 & 0.01 & 588 & 610 \\
\hline \hline Total: & 1.50 & 3.68 & 8.79 & 5.19 & 8.39 & 28.05 & 0.09 & 14,103 & 14,774 \\
\hline
\end{tabular}




\section{Summary}

- Dome shape and carbon fiber thickness were determined by netting analysis

- Minimum tank pressure affects system gravimetric and volumetric capacities while tank geometry (L/D) affects only gravimetric capacity

- WTT efficiency is within six percentage points of DOE target of $60 \%$

- For $5.6 \mathrm{~kg}$ recoverable $\mathrm{H}_{2}$ in Type IV single tank system, and L/D $=3$

\begin{tabular}{|c|c|c|c|c|c|c|}
\hline $\begin{array}{c}\mathrm{H}_{2} \text { Tank } \\
\text { Pressure } \\
\text { (bar) }\end{array}$ & $\begin{array}{c}\text { Minimum } \\
\text { Pressure } \\
\text { (bar) }\end{array}$ & $\begin{array}{c}\text { Gravimetric } \\
\text { Capacity } \\
(\mathrm{w} \% \text { \%) }\end{array}$ & $\begin{array}{c}\text { Volumetric } \\
\text { Capacity } \\
(\mathrm{g} / \mathrm{L})\end{array}$ & $\begin{array}{c}\text { Electricity } \\
(\mathrm{kWh} / \mathrm{kg})\end{array}$ & $\begin{array}{c}\text { WTT } \\
\text { Efficiency } \\
(\%)\end{array}$ & $\begin{array}{c}\mathrm{GHG} \\
\left(\mathrm{kg} / \mathrm{kg}-\mathrm{H}_{2}\right)\end{array}$ \\
\hline 350 & 20 & 5.5 & 17.6 & 2.9 & 56.5 & 14.2 \\
350 & 3 & 5.8 & 18.6 & 2.9 & 56.5 & 14.2 \\
700 & 20 & 5.2 & 26.3 & 3.7 & 54.2 & 14.8 \\
700 & 3 & 5.3 & 27.2 & 3.7 & 54.2 & 14.8 \\
\hline
\end{tabular}

\section{Summary}

- For $5.6 \mathrm{~kg}$ recoverable $\mathrm{H}_{2}$ in Type III, Type IV single and dual tank systems, and $\mathrm{L} / \mathrm{D}=3$

\begin{tabular}{|c|c|c|c|c|c|c|c|c|c|c|c|c|}
\hline Performance and Cost Metric & Units & $\begin{array}{c}\mathrm{cH} 2 \\
350-\mathrm{T} 3 \\
\end{array}$ & $\begin{array}{c}\mathrm{cH} 2 \\
350-\mathrm{T} 3 \\
\end{array}$ & $\begin{array}{c}\mathrm{cH} 2 \\
350-\mathrm{T} 4 \\
\end{array}$ & $\begin{array}{c}\mathrm{CH} 2 \\
350-\mathrm{T} 4 \\
\end{array}$ & $\begin{array}{c}\mathrm{cH} 2 \\
700-\mathrm{T} 3 \\
\end{array}$ & $\begin{array}{c}\mathrm{CH} 2 \\
700-\mathrm{T} 3 \\
\end{array}$ & $\begin{array}{c}\mathrm{CH} 2 \\
700-\mathrm{T} 4 \\
\end{array}$ & $\begin{array}{c}\mathrm{CH} 2 \\
700-\mathrm{T} 4 \\
\end{array}$ & $\begin{array}{c}2010 \\
\text { Targets }\end{array}$ & $\begin{array}{c}2015 \\
\text { Targets } \\
\end{array}$ & $\begin{array}{l}\text { Ultimate } \\
\text { Targets }\end{array}$ \\
\hline Tank & & 1-Tank & 2-Tank & 1-Tank & 2-Tank & 1-Tank & 2-Tank & 1-Tank & 2-Tank & & & \\
\hline Total Storage Capacity & $\mathrm{kg} \cdot \mathrm{H}_{2}$ & 6.0 & 6.0 & 6.0 & 6.0 & 5.8 & 5.8 & 5.8 & 5.8 & & & \\
\hline \begin{tabular}{|l} 
Usable Storage Capacity \\
\end{tabular} & $\mathrm{kg}-\mathrm{H}_{2}$ & 5.6 & 5.6 & 5.6 & 5.6 & 5.6 & 5.6 & 5.6 & 5.6 & & & \\
\hline System Gravimetric Capacity & $\mathrm{w}+\%$ & 4.2 & 4.0 & 5.5 & 5.0 & 3.6 & 3.5 & 5.2 & 4.8 & 4.5 & 5.5 & 7.5 \\
\hline System Volumetric Capacity & $\mathrm{kg} \cdot \mathrm{H}_{2} / \mathrm{m}^{3}$ & 17.4 & 17.2 & 17.6 & 17.2 & 25.0 & 24.7 & 26.3 & 25.6 & 28 & 40 & 70 \\
\hline \begin{tabular}{|l} 
Storage System Cost \\
\end{tabular} & $\$ / k W h$ & 16.8 & 16.9 & 15.4 & 15.8 & 21.2 & 21.4 & 18.7 & 19.2 & 4 & 2 & TBD \\
\hline Fuel Cost & \$/gge & 4.2 & 4.2 & 4.2 & 4.2 & 4.3 & 4.3 & 4.3 & 4.3 & $2-3$ & $2-3$ & $2-3$ \\
\hline Cycle Life ( $1 / 4$ tank to Full) & Cycles & 5500 & 5500 & $\mathrm{NA}$ & $\mathrm{NA}$ & 5500 & 5500 & $\mathrm{NA}$ & $\mathrm{NA}$ & 1000 & 1500 & 1500 \\
\hline Minimum Delivery Pressure, $\mathrm{FC} / \mathrm{ICE}$ & atm & 4 & 4 & 4 & 4 & 4 & 4 & 4 & 4 & $4 / 35$ & $3 / 35$ & $3 / 35$ \\
\hline WTT Efficiency & $\%$ & 56.5 & 56.5 & 56.5 & 56.5 & 54.2 & 54.2 & 54.2 & 54.2 & 60 & 60 & 60 \\
\hline GHG Emissions $\left(\mathrm{CO}_{2}\right.$ eq) & $\mathrm{kg} / \mathrm{kg}-\mathrm{H}_{2}$ & 14.2 & 14.2 & 14.2 & 14.2 & 14.8 & 14.8 & 14.8 & 14.8 & & & \\
\hline Ownership Cost & $\$ /$ mile & 0.13 & 0.13 & 0.13 & 0.13 & 0.15 & 0.15 & 0.14 & 0.14 & & & \\
\hline
\end{tabular}




\section{APPENDIX B}

Cost Assessment of Compressed Hydrogen Storage Systems 


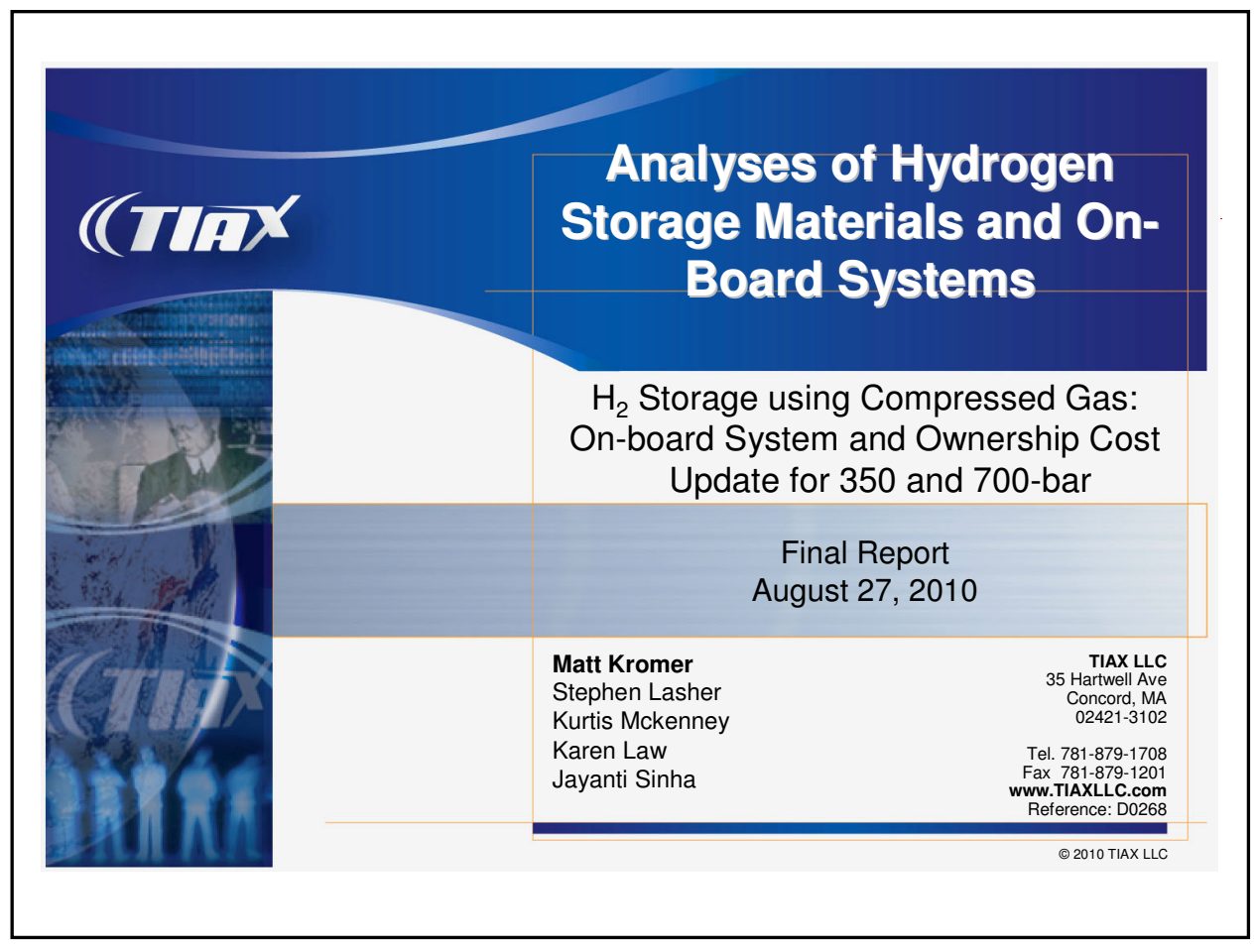

Sections

\begin{tabular}{|l|l|}
\hline 1 & Executive Summary \\
\hline 2 & On-board Assessment \\
\hline 3 & Off-board Assessment \\
\hline 4 & Conclusions \\
\hline A & Appendix \\
\hline
\end{tabular}


Summary

We have evaluated characteristics of on-board and off-board hydrogen storage systems for 11 storage technologies.

\begin{tabular}{|c|c|c|c|c|c|c|c|c|c|c|c|c|}
\hline \multicolumn{2}{|c|}{ Analysis To Date } & $\mathrm{cH}_{2}$ & Alanate & $\mathrm{MgH}_{2}$ & SBH & $\mathrm{LCH}_{2}$ & $\mathrm{CcH}_{2}$ & $\mathrm{LH}_{2}$ & $\mathrm{AC}$ & $\begin{array}{l}\text { MOF- } \\
177\end{array}$ & $\begin{array}{l}\text { Cold } \\
\text { Gas }\end{array}$ & $\mathrm{AB}$ \\
\hline \multirow{4}{*}{$\begin{array}{l}\text { On- } \\
\text { Board }\end{array}$} & $\begin{array}{l}\text { Review developer } \\
\text { estimates }\end{array}$ & $\sqrt{ }$ & $\sqrt{ }$ & & $\sqrt{ }$ & $\sqrt{ }$ & $\sqrt{ }$ & $\sqrt{ }$ & $\sqrt{ }$ & $\sqrt{ }$ & & \\
\hline & $\begin{array}{l}\text { Develop process flow } \\
\text { diagrams/system energy } \\
\text { balances (ANL lead) }\end{array}$ & $\sqrt{ }$ & $\sqrt{ }$ & & $\sqrt{ }$ & $\sqrt{ }$ & $\sqrt{ }$ & $\sqrt{ }$ & & $\sqrt{ }$ & & \\
\hline & $\begin{array}{l}\text { Performance assessment } \\
\text { (ANL lead) }\end{array}$ & $\sqrt{ }$ & $\sqrt{ }$ & & $\sqrt{ }$ & $\sqrt{ }$ & $\sqrt{ }$ & $\sqrt{ } *$ & & $\sqrt{ } *$ & & \\
\hline & $\begin{array}{l}\text { Independent cost } \\
\text { assessment }\end{array}$ & $\sqrt{ }$ & $\sqrt{ }$ & & $\sqrt{ }$ & $\sqrt{ }$ & $\sqrt{ }$ & $\sqrt{ } *$ & WIP & $\sqrt{*}$ & & \\
\hline \multirow{4}{*}{$\begin{array}{l}\text { Off- } \\
\text { Board }\end{array}$} & $\begin{array}{l}\text { Review developer } \\
\text { estimates }\end{array}$ & $\sqrt{ }$ & & $\sqrt{ }$ & $\sqrt{ }$ & $\sqrt{ }$ & $\sqrt{ }$ & $\sqrt{ }$ & & & $\sqrt{ }$ & $\sqrt{ }$ \\
\hline & $\begin{array}{l}\text { Develop process flow } \\
\text { diagrams/system energy } \\
\text { balances }\end{array}$ & $\sqrt{ }$ & & $\sqrt{ }$ & $\sqrt{ }$ & $\sqrt{ }$ & & & & & $\sqrt{ }$ & $\sqrt{ }$ \\
\hline & $\begin{array}{l}\text { Performance assessment } \\
\text { (energy, GHG) }^{\mathrm{a}}\end{array}$ & $\sqrt{ }$ & & & $\sqrt{ }$ & $\sqrt{ }$ & & & & & $\sqrt{ }$ & \\
\hline & $\begin{array}{l}\text { Independent cost } \\
\text { assessment }^{\mathrm{a}}\end{array}$ & $\sqrt{ }$ & & & $\sqrt{ }$ & $\sqrt{ }$ & & $\sqrt{ }$ & & & $\sqrt{ }$ & \\
\hline \multirow{3}{*}{ Overall } & Ownership cost projection & $\sqrt{ }$ & & & $\sqrt{ }$ & $\sqrt{ }$ & & $\sqrt{ }$ & & $\sqrt{ }$ & $\sqrt{*}$ & \\
\hline & $\begin{array}{l}\text { Solicit input on TIAX } \\
\text { analysis }\end{array}$ & $\sqrt{ }$ & $\sqrt{ }$ & & $\sqrt{ }$ & $\sqrt{ }$ & $\sqrt{ }$ & $\sqrt{*}$ & WIP & $\sqrt{ } *$ & & \\
\hline & Analysis update & $\sqrt{ }$ & & & $\sqrt{ }$ & & $\sqrt{ }$ & WIP & & WIP & & \\
\hline \multicolumn{13}{|c|}{$\begin{array}{l}\text { * Preliminary results under review. } \\
\text { a Work with SSAWG, ANL and SSAWG participants on WTT an }\end{array}$} \\
\hline
\end{tabular}

Executive Summary Background Timeline

This report summarizes our updated compressed hydrogen storage assessment for $\mathbf{3 5 0}$ and $\mathbf{7 0 0}$-bar tanks.

\begin{tabular}{|c|c|c|}
\hline Technology Focus & $2004-2007$ & $2008-2010$ \\
\hline $\begin{array}{l}\text { On-Board Storage System } \\
\text { Assessment }\end{array}$ & $\begin{array}{l}\text { - Compressed Hydrogen } \\
\text { - 350-bar } \\
\text { - } 700 \text {-bar } \\
\text { - Metal Hydride } \\
\text { - Sodium Alanate } \\
\text { - Chemical Hydride } \\
\text { - Sodium Borohydride }\left(\mathrm{SBH}^{2}\right) \\
\text { - Magnesium Hydride }\left(\mathrm{MgH}_{2}\right) \\
\text { - Cryogenic Hydrogen } \\
\text { - Cryo-compressed }\end{array}$ & $\begin{array}{l}\text { - Compressed Hydrogen } \\
\text { - 350-bar - update } \\
\text { - 700-bar - update } \\
\text { - Chemical Hydride } \\
\text { - Liquid Hydrogen Carrier }\left(\mathrm{LCH}_{2}\right) \\
\text { - Cryogenic Hydrogen } \\
\text { - Cryo-compressed - update } \\
\text { - Liquid Hydrogen }\left(\mathrm{LH}_{2}\right)-\text { WIP } \\
\text { - Activated Carbon - WIP } \\
\text { - MOF-177 }\end{array}$ \\
\hline $\begin{array}{l}\text { Off-Board Fuel Cycle } \\
\text { Assessment }\end{array}$ & $\begin{array}{l}\text { - Compressed Hydrogen } \\
\text { - 350-bar } \\
\text { - 700-bar } \\
\text { - Chemical Hydride } \\
\text { - Sodium Borohydride (SBH) }\end{array}$ & $\begin{array}{l}\text { - Compressed Hydrogen } \\
\text { - 350-bar - update } \\
\text { - 700-bar - update } \\
\text { - Chemical Hydride } \\
\text { - Liquid Hydrogen Carrier }\left(\mathrm{LCH}_{2}\right) \\
\text { - Ammonia Borane } \\
\text { - Cryogenic Hydrogen } \\
\text { - Cryo-compressed } \\
\text { - Liquid Hydrogen }\left(\mathrm{LH}_{2}\right)-\text { WIP }\end{array}$ \\
\hline
\end{tabular}


Executive Summary Background System Configurations

Since completing initial analysis of compressed hydrogen storage systems in 2006, TIAX has periodically updated results to reflect revised assumptions and conduct additional analysis.

In total, TIAX conducted analyses of eight different compressed tank configurations by varying the pressure, number of tanks, and liner type:

\begin{tabular}{|c|c|c|c|}
\hline Case & Pressure (Bar) & \# of tanks & Liner Type \\
\hline $\mathbf{1 - 3 5 0 - B a r ~ b a s e ~ c a s e ~}$ & 350 & 1 & HDPE (Type IV) \\
\hline $\mathbf{2 - 7 0 0 - B a r ~ b a s e ~ c a s e ~}$ & 700 & 1 & HDPE (Type IV) \\
\hline $\mathbf{3}$ & 350 & 2 & HDPE (Type IV) \\
\hline $\mathbf{4}$ & 700 & 2 & HDPE (Type IV) \\
\hline $\mathbf{5}$ & 350 & 1 & Aluminum (Type III) \\
\hline $\mathbf{6}$ & 700 & 1 & Aluminum (Type III) \\
\hline $\mathbf{7}$ & 350 & 2 & Aluminum (Type III) \\
\hline $\mathbf{8}$ & 700 & 2 & Aluminum (Type III) \\
\hline
\end{tabular}

$\rightarrow$ The base cases refer to Type IV (HDPE lined) single tank systems at pressures of 350 and 700 bar.

$\rightarrow$ The other six cases are discussed as sensitivity cases throughout this report.

\section{(TIAX}

Executive Summary Background Schematic

Our assessment is based primarily on Quantum's Type IV compressed hydrogen storage tanks, which they manufacture in low volumes today.

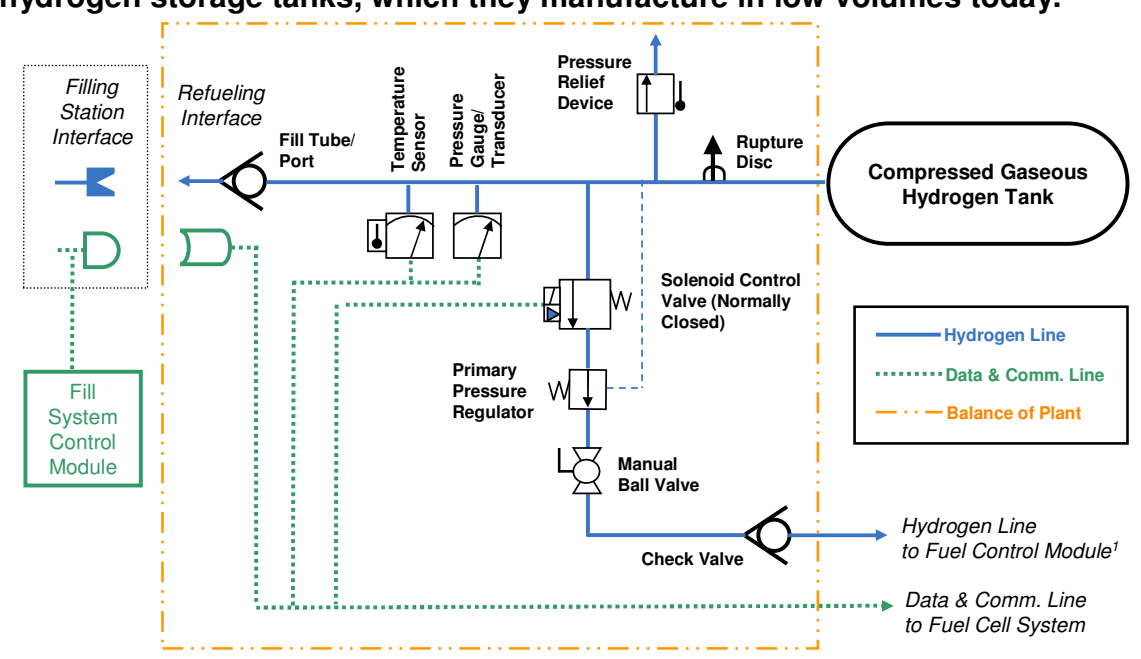

* Schematic based on the requirements defined in the draft European regulation "Hydrogen Vehicles: On-board Storage Systems" and US Patent 6,041,762 Secondary Pressure Regulator located in Fuel Control Module of the Fuel Cell System. 
Executive Summary On-board Assessment Factory Cost Comparison-Base Cases

The base case Type IV compressed systems' high-volume costs are projected to be 4-5 times higher than the current DOE 2010 cost target of $\$ 4 / \mathrm{kWh}$.

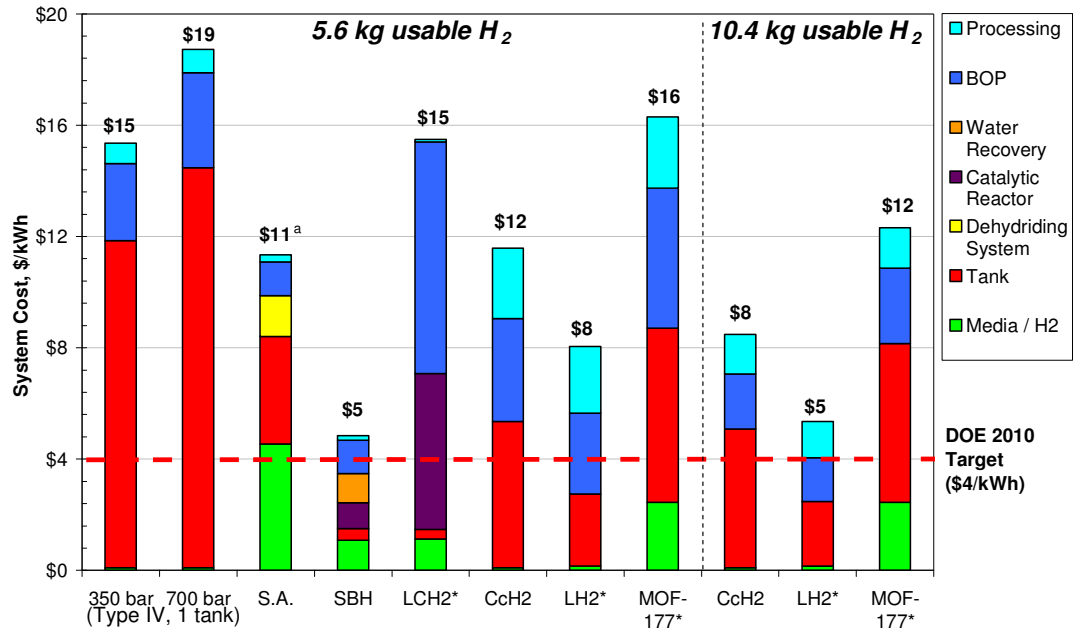

Note: not all hydrogen storage systems shown are at the same stage of development, and each would have different on-board performance characteristics. alanate system requires high temp. waste heat for hydrogen desorption, otherwise the usable hydrogen capacity would be reduced.

Executive Summary On-board Assessment Factory Cost Comparison - Type III and dual tank systems

Cost estimates for Type III tanks and dual tank systems project a modest cost increase compared to the Type IV, single tank baseline.

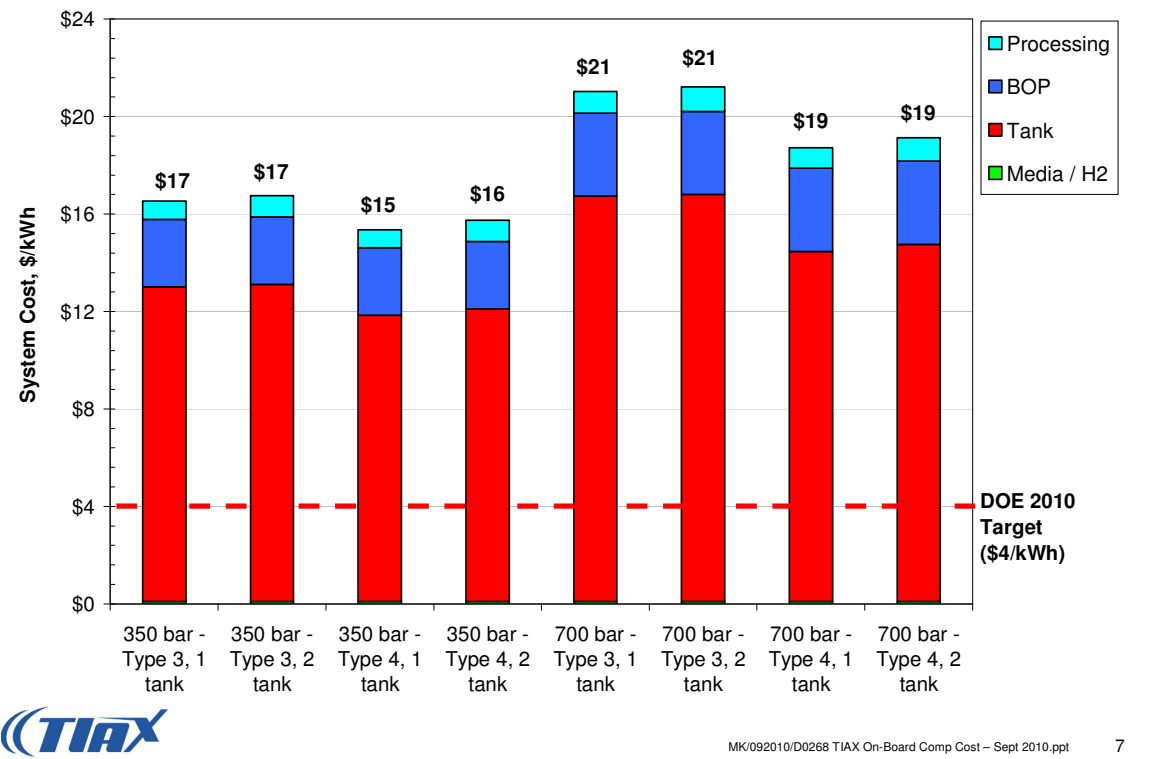


Executive Summary Off-board Assessment Hydrogen Cost Comparison-Base Cases

The compressed system refueling costs are projected to be 1.5-2 times more expensive than the current DOE target range of $\$ 2-3 / \mathrm{kg}$.

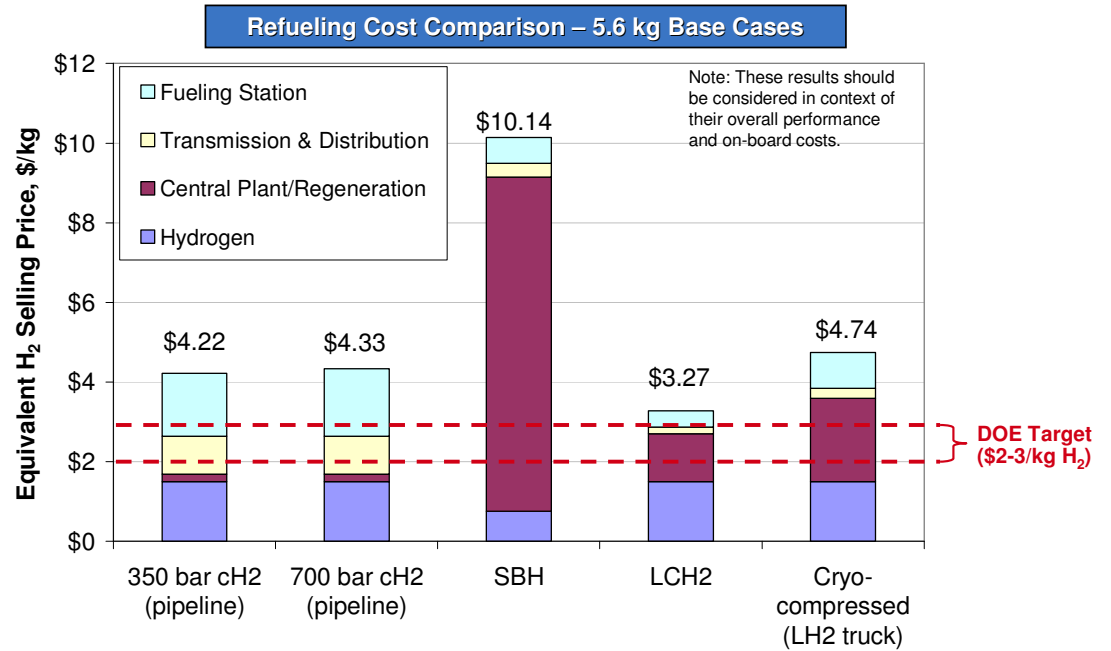

Note: 350-bar, 700-bar and cryo-compressed results were calculated using the base case delivery scenarios in HDSAM v2.06. SBH and $\mathrm{LCH}_{2}$ results were Note: $350-$-bar, 700-bar and cryo-compressed results were calculated using the base case delivery scenarios in
calculated using a modified H2A Delivery Components Carrier Model v34. All fuel costs exclude fuel taxes.

( (IIAX)

Off-board Assessment Results Ownership Cost Comparison-Base Cases

Fuel system ownership cost for the base case compressed systems are projected to be $30-50 \%$ more expensive than gasoline at $\$ 3.00 /$ gal.

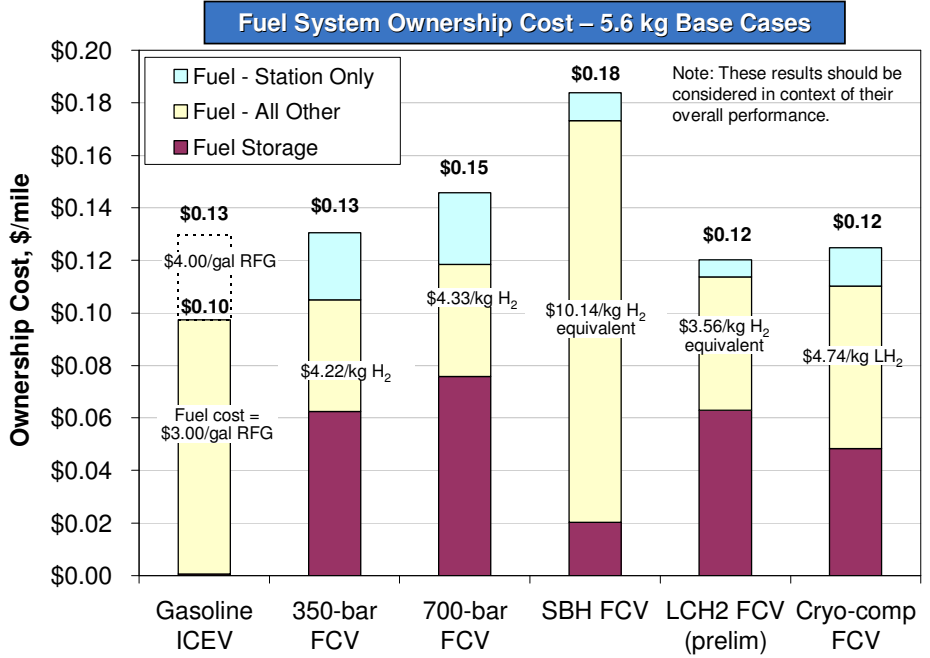

Note: All fuel costs exclude fuel taxes. 
Executive Summary Conclusions

System costs are significantly higher than the current targets and do not have a clear path to achieve the DOE's long-term goals

- The high-volume manufactured cost projections of the on-board storage systems are 4-5 times the current DOE 2010 cost target

$>$ 350-bar and 700-bar Type IV systems are projected to cost $\$ 15 / \mathrm{kWh}$ and $\$ 19 / \mathrm{kWh}$

$>$ Type III tanks add $\$ 1.2 / \mathrm{kWh}$ (350-bar) to $\$ 2.2 / \mathrm{kWh}$ (700-bar) to the cost of Type IV tanks

$>$ Dual tank systems add $<\$ 0.5 / \mathrm{kWh}$ to the cost of hydrogen storage systems.

- Factory costs will likely range (95\% confidence) between $\$ 10.6$ and $\$ 19.7 / \mathrm{kWh}$ for the 350-bar system and between $\$ 13.5$ and $\$ 27.2 / \mathrm{kWh}$ for the 700 -bar system

- Refueling costs based on $\mathrm{H}_{2}$ pipeline delivery and high-pressure $\mathrm{H}_{2}$ dispensing, are projected to be 1.5-2 times more expensive than the DOE cost target of $\$ 2-3 / \mathrm{kg}$

- Compressed fuel system ownership costs will likely be about 30-50\% (3-5 c/mi or $\$ 250-600 / \mathrm{yr}$ ) higher than a conventional gasoline ICEV when gasoline is $\$ 3.00 / \mathrm{gal}$

$>$ 350-bar fuel system ownership costs would be comparable to gasoline at $\$ 4.00 / \mathrm{gal}$

$>$ 700-bar fuel system ownership costs would be comparable to gasoline at $\$ 4.50 / \mathrm{gal}$

When on-board and off-board costs are combined, the 350-bar compressed system has potential to have similar ownership costs as a gasoline ICEV.

(C) Note: All fuel costs exclude fuel taxes.

\begin{tabular}{|l|l|}
\hline 1 & Executive Summary \\
\hline 2 & On-board Assessment \\
\hline & Approach \\
\hline & Analysis \\
\hline & Results \\
\hline 3 & Off-board Assessment \\
\hline 4 & Conclusions \\
\hline A & Appendix \\
\hline
\end{tabular}


On-board Assessment Approach Previous Assessment

In 2004-2006, under a previous DOE contract 1 , TIAX evaluated the cost of compressed hydrogen $\left(\mathrm{CH}_{2}\right)$ storage systems.
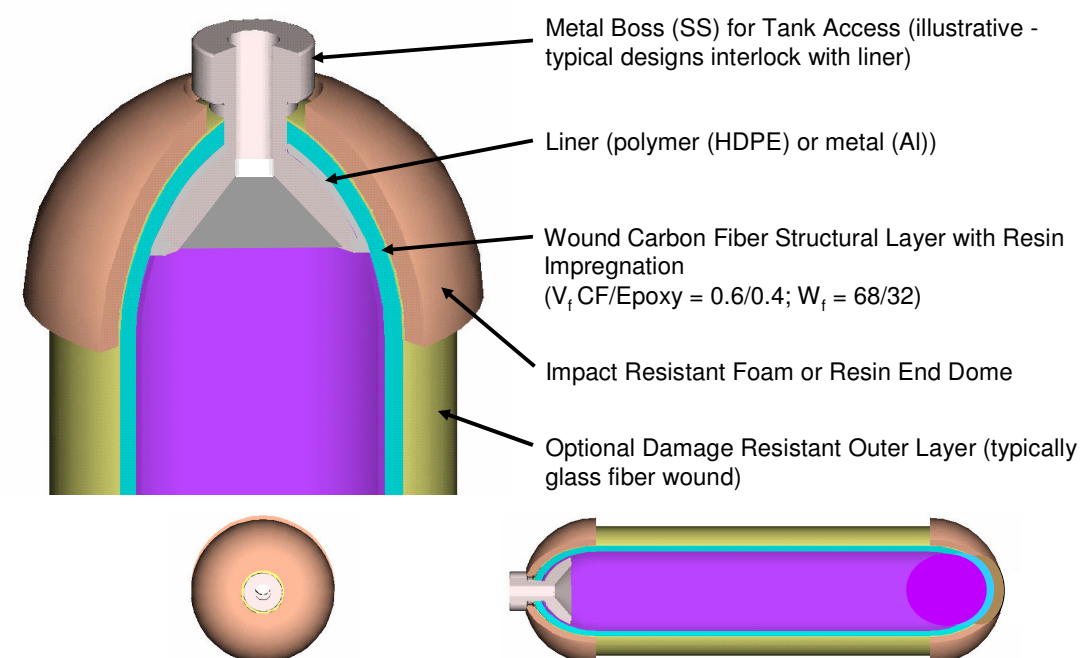

Carlson, E. et al; "Cost Assessment of PEM Fuel Cells for Transportation Application"; DOE Annual Merit Review, May 2004, Washington DC

On-board Assessment Approach System Configurations

Since 2006, TIAX has periodically updated results to reflect revised assumptions and conduct additional analysis.

In total, TIAX conducted analysis of eight different compressed tank configurations by varying the following parameters:

- Pressure: Pressures of 350 and 700 bar

- Number of tanks: Single- and dual-tank systems

- Tank liner: Type III (Aluminum lined) and Type IV (HDPE lined) pressure vessels

\begin{tabular}{|c|c|c|c|}
\hline Case & Pressure (Bar) & \# of tanks & Liner Type \\
\hline 1-350-Bar base case & 350 & 1 & HDPE (Type IV) \\
\hline $\mathbf{2}-$ 700-Bar base case & 700 & 1 & HDPE (Type IV) \\
\hline $\mathbf{3}$ & 350 & 2 & HDPE (Type IV) \\
\hline $\mathbf{4}$ & 700 & 2 & HDPE (Type IV) \\
\hline $\mathbf{5}$ & 350 & 1 & Aluminum (Type III) \\
\hline $\mathbf{6}$ & 700 & 1 & Aluminum (Type III) \\
\hline $\mathbf{7}$ & 350 & 2 & Aluminum (Type III) \\
\hline $\mathbf{8}$ & 700 & 2 & Aluminum (Type III) \\
\hline
\end{tabular}


On-board Assessment Approach Schematic

The system schematic ${ }^{1}$ and bill of materials for the compressed systems were generated through discussions with tank developers. Each of the system design configurations evaluated employs a similar system architecture.

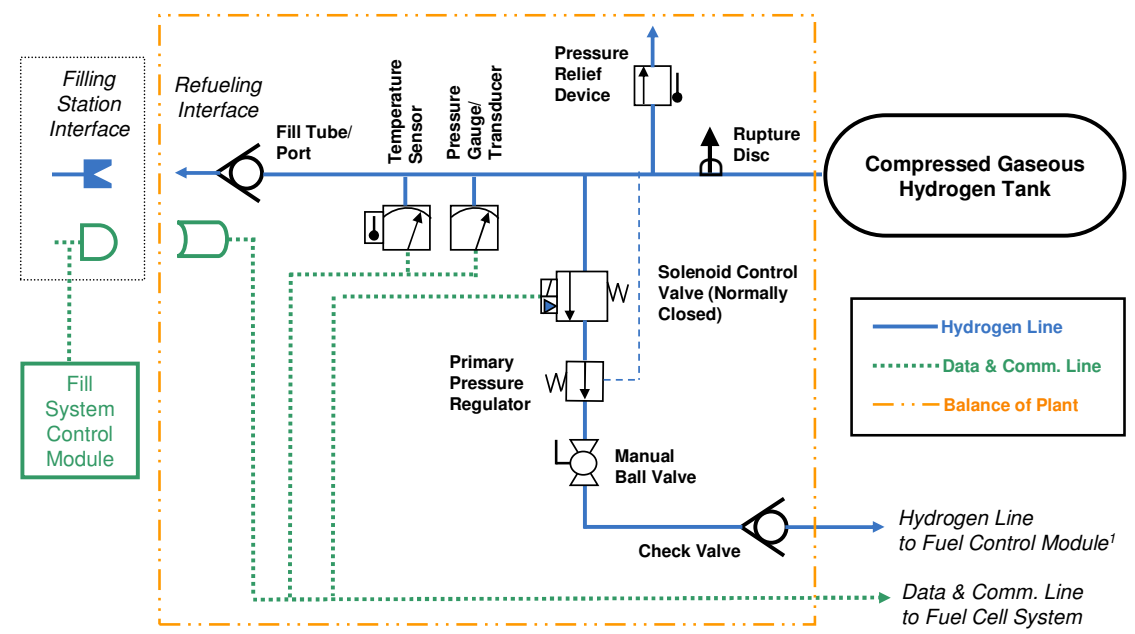

${ }^{1}$ Schematic based on the requirements defined in the draft European regulation "Hydrogen Vehicles: On-board Storage Systems" and US Patent 6,041,762. ${ }^{2}$ Secondary Pressure Regulator located in Fuel Control Module of the Fuel Cell System.

(TIAX

On-board Assessment Approach Bottom-Up Approach

The high volume $\left(500,000\right.$ units/year) manufactured cost for all $\mathrm{H}_{2}$ storage systems is estimated from raw material prices, capital equipment, labor, and other operating costs.

\section{BOP Bottom-up Costing Methodology}

$>$ Develop Bill of Materials (BOM)

$>$ Obtain raw material prices from potential suppliers

> Develop manufacturing process map for key subsystems and components

$>$ Estimate manufacturing costs using TIAX cost models (capital equipment, raw material price, labor rates)

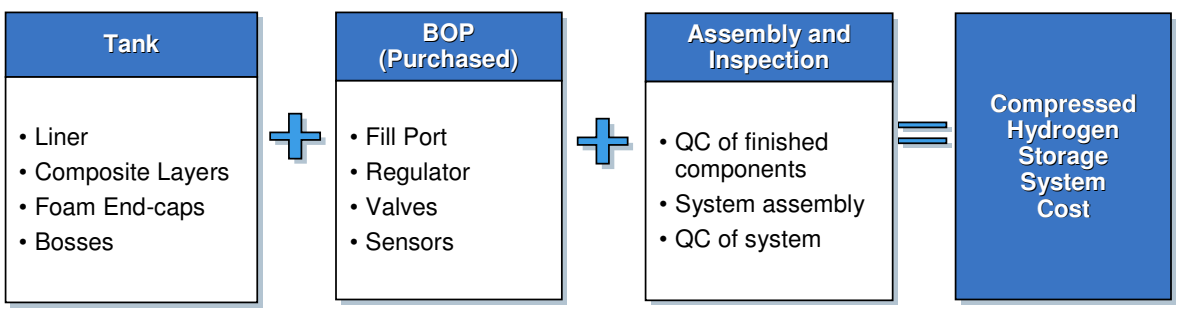

We modeled material and manufacturing process costs for the compressed tanks, while assuming that the BOP is purchased. 
On-board Assessment Approach Carbon Fiber Tank Process Flow

The Type IV tanks require composite winding steps that are well established and mature technologies within the Compressed Natural Gas Industry.

\section{Type IV Carbon Fiber Tank Manufacturing Process Map}

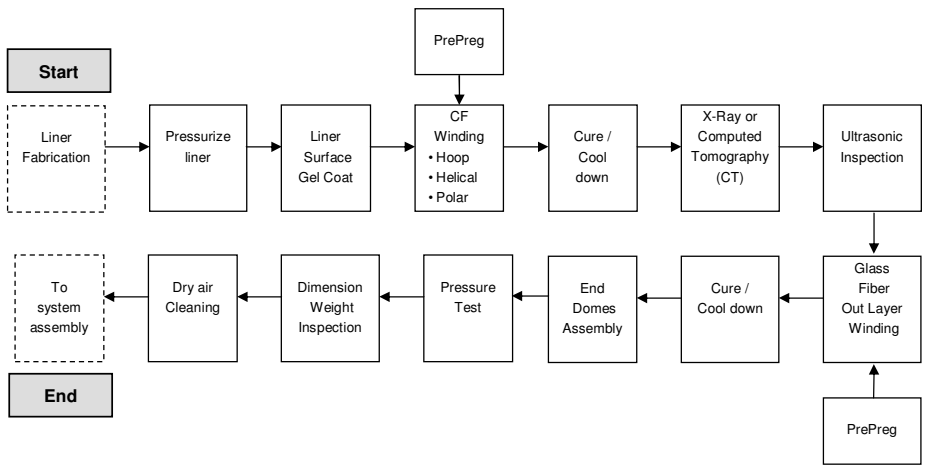

We also assume the system manufacturer purchases pre-impregnated (i.e., "prepreg") carbon fiber composite as apposed to raw carbon fiber. 1

Note: About 60 winding machines would be required for 500,000 350-bar tanks per year; about 100 machines would be required for 700-bar tanks. See Appendix for details.

( (IIAX)

On-board Assessment Approach Carbon Fiber Tank Process Flow

Type III aluminum lined tanks use a similar process to Type IV tanks, but include an additional step for autofrettage, a method that reduces the mean stress on the pressurized tank. ${ }^{1}$

\section{Type III Carbon Fiber Tank Manufacturing Process Map}

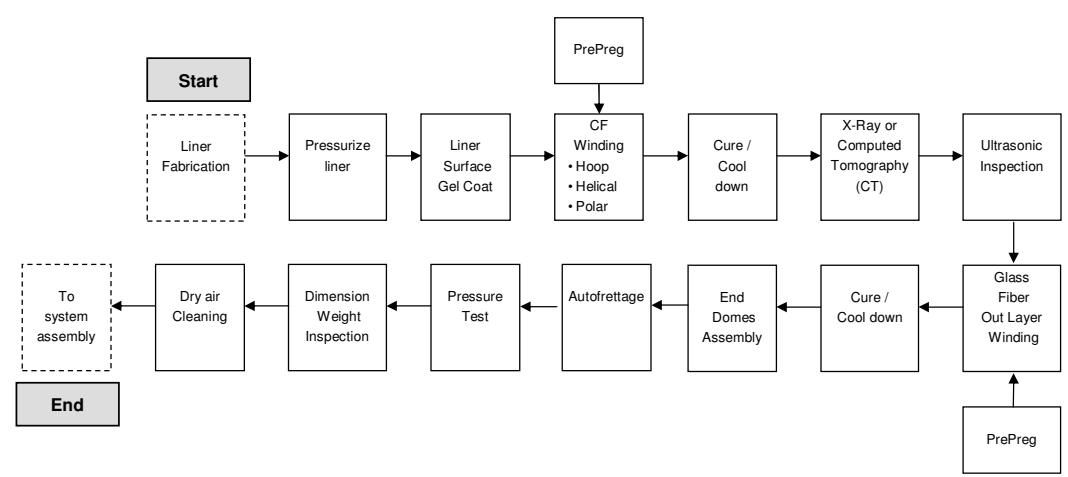

${ }^{1}$ Autofrettage entails pressurizing the liner past its yields point to induce a residual compressive stress in the liner. The vessel's pressurized contents act in opposition to this compressive stress, thereby reducing the mean stress.

Note: About 60 winding machines would be required for 500,000 350-bar tanks per year; about 100 machines would be required for 700-bar tanks. 
On-board Assessment Approach BOP Cost Estimation

\section{We developed BOP cost projections for high-volume production using the Delphi method with validation from Top-down and Bottom-up estimates.}

- We obtained input from developers on their cost projections for BOP components

$>$ Tank developers are considering the issue of automotive scale production

$>$ But, they do not produce tanks at such large scales today

- Feedback from some Automotive OEMs suggested that these projections did not account for process or technology changes that would be required for automotive scale production

$>$ High pressure components are often built-to-order or produced in low volumes, so "processing costs" are typically high

> Vendor quotes contain unspecified markups, which can be substantial in the industry these devices are currently used (unlike the automotive industry, purchasing power of individual buyers is not very strong)

$>$ Low-volume quotes are sometimes based on laboratory and/or custom components that often exceed the base case system requirements

- Therefore, we developed BOP cost projections that were more in-line with OEM estimates for high-volume production using the Delphi method with validation from:

> Top-down estimates - high-volume discounts applied to low-volume vendor quotes using progress ratios

$>$ Bottom-up estimates - cost modeling using DFMA ${ }^{\circledR}$ software plus mark-ups

BOP costs were reduced significantly this year based on industry feedback.

( (IITX

On-board Assessment Analysis Design Assumptions-Base Cases

\section{Key Design Assumptions: Compressed Gaseous Tanks}

\begin{tabular}{|c|c|c|}
\hline Design Parameter & Base Case Value & Basis/Comment \\
\hline Nominal pressure & 350 and 700 bar & Design assumptions based on DOE and industry input \\
\hline Number of tanks & Single and dual & $\begin{array}{l}\text { Design assumptions based on DOE and industry input - base case } \\
\text { results reflect single tank systems }\end{array}$ \\
\hline Tank liner & $\begin{array}{l}\text { Type III (Aluminum) } \\
\text { Type IV (HDPE) }\end{array}$ & $\begin{array}{l}\text { Design assumptions based on DOE and industry input - base case } \\
\text { results reflect Type IV tanks }\end{array}$ \\
\hline Maximum (filling) pressure ${ }^{1}$ & $\begin{array}{l}\text { 350-bar: } 438 \text { bar } \\
\text { 700-bar: } 875 \text { bar }\end{array}$ & $\begin{array}{l}125 \% \text { of nominal design pressure is assumed required for fast fills to } \\
\text { prevent under-filling }\end{array}$ \\
\hline Minimum (empty) pressure & 20 bar & Discussions with Quantum, 2008 \\
\hline Usable $\mathrm{H}_{2}$ storage capacity & $5.6 \mathrm{~kg}$ & $\begin{array}{l}\text { Design assumption based on ANL drive-cycle modeling for FCV } 350 \\
\text { mile range for a midsized vehicle }\end{array}$ \\
\hline $\begin{array}{l}\text { Recoverable hydrogen } \\
\text { (fraction of stored } \mathrm{H}_{2} \text { ) }\end{array}$ & $\begin{array}{l}350 \text { bar: } 93 \% \\
700 \text { bar: } 98 \%\end{array}$ & $\begin{array}{l}\text { ANL calculation based on hydrogen storage density at maximum and } \\
\text { minimum pressure and temperature conditions }\end{array}$ \\
\hline Tank size (water capacity) & $\begin{array}{l}\text { 350-bar: } 258 \mathrm{~L} \\
\text { 700-bar: } 149 \mathrm{~L}\end{array}$ & $\begin{array}{l}\text { ANL calculation for } 5.6 \mathrm{~kg} \text { useable } \mathrm{H}_{2} \text { capacity }\left(6.0 \text { and } 5.8 \mathrm{~kg} \text { total } \mathrm{H}_{2}\right. \\
\text { capacity for } 350 \text { and } 700 \text {-bar tanks, respectively) }\end{array}$ \\
\hline Safety factor & 2.25 & Industry standard specification (e.g., ISO/TS 15869) ${ }^{1}$ \\
\hline L/D ratio & 3.0 & $\begin{array}{l}\text { Discussions with Quantum, 2008; based on the outside of the CF } \\
\text { wrapped tank }\end{array}$ \\
\hline
\end{tabular}


On-board Assessment Analysis Design Assumptions-Base Cases

Key Design Assumptions (continued): Compressed Gaseous Tanks

\begin{tabular}{|l|c|l|}
\hline \multicolumn{1}{|c|}{ Design Parameter } & Base Case Value & \multicolumn{1}{c|}{ Basis/Comment } \\
\hline Carbon fiber type & Toray T700S & $\begin{array}{l}\text { Discussions with Quantum and other developers, 2008; assumed to } \\
\text { have a composite strength of 2,550 MPa for 60\% fiber by volume }\end{array}$ \\
\hline Translation strength factors & $\begin{array}{c}350 \text {-bar: } 82.5 \% \\
700-\text { bar: } 80.0 \%\end{array}$ & ANL assumption based on data from Quantum, 2004-09 \\
\hline Composite tensile strength & $2,550 \mathrm{MPa}$ & Toray material data sheet for 60\% fiber by volume \\
\hline Adjustment for CF quality & $10 \%$ & $\begin{array}{l}\text { Reduction in average tensile strength to account for variance in CF } \\
\text { quality, based on discussion with Quantum and other developers, } 2010\end{array}$ \\
\hline Tank liner thickness & $\begin{array}{c}5 \mathrm{~mm} \text { HDPE (Type IV) } \\
7.4 \mathrm{~mm} \text { Al (Type III) }\end{array}$ & $\begin{array}{l}\text { HDPE: Discussions with Quantum, 2008; typical for Type IV tanks } \\
\text { Al: ANL assumption, typical for Type III tanks }\end{array}$ \\
\hline Overwrap & $1 \mathrm{~mm}$ glass fiber & Discussions with Quantum, 2008; common but not functionally required \\
\hline Protective end caps & $10 \mathrm{~mm}$ foam & Discussions with Quantum, 2008; for impact protection \\
\hline
\end{tabular}

(C) ${ }^{1}$ Tank design based on nominal pressure not maximum pressure.

On-board Assessment Analysis Design Updates-2009

In 2009, we updated our previous compressed tank design analysis based on collaboration with DOE, Quantum, SCl, Toray and ANL.

- Tank safety factor was applied to the nominal tank pressure (i.e., 350 and 700 bar) rather than max. filling over pressure (i.e., 438 and 875 bar) based on new information from industry

- Tank end dome shape and carbon fiber thicknesses were modified based on ANL's latest performance analysis, which uses a composite pressure vessel algorithm ${ }^{1}$

$>$ Combination of geodesic and hoop windings assumed, with only geodesic windings on the end domes

$>$ Non-uniform end dome thickness; thickest at dome peak (exit hole)

> Model yields carbon fiber weight calculations consistent with Quantum's models

- Carbon fiber composite tensile strength decreased from 2,940 to 2,550 MPa to be consistent with ANL's latest performance analysis

- Most BOP component costs were reduced significantly based on industry feedback ${ }^{2}$

- Other less significant changes were made based on the latest industry feedback or to match the latest ANL assumptions

> Nominal tank design pressure increased to 350 and 700 bar rather than 5,000 psi (345 bar) and 10,000 psi (689 bar)

> Minimum tank design pressure changed from 28 bar (400 psi) for 350-bar tanks and 14 bar (200 psi) for 700-bar tanks to 20 bar (290 psi) for both

$>$ Tank geometry: L/D ratio of $3 / 1$ based on the outside of the composite tank 
On-board Assessment Analysis Design Updates-2010

In 2010, we expanded our analysis to include alternate tank configurations and continued to revise key assumptions based on feedback from industry.

- Type III (Aluminum lined tank) and two-tank system designs were evaluated based on ANL's performance assessment

$>$ The two-tank system design uses two identical pressure vessels that each hold half of the fuel. However, the two tank system's balance-of-plant is identical to that used for the one tank system (i.e., a single set of component regulates operation for both tanks).

> The Type III tank's aluminum liner is designed to support a portion of the tank's pressure load, thereby reducing the total carbon fiber requirement.

- The average carbon fiber composite strength was reduced by $10 \%$ to account for variability in carbon fiber quality based on DOE discussions with industry

- Translation strength factor was increased for the 700 bar tank from $63 \%$ to $80 \%$ based on ANL discussions with Quantum

- Additional BOP components were added based on ANL feedback from industry

> Additional manual service vent valve, check valve, pressure release device, and rupture disks

$>$ Additional solenoid shutoff valves

On balance, the 2009 and 2010 updates increased the cost of the 350 bar systems by $\sim \$ 2 / \mathrm{kWh}$ and decreased the cost of the 700 bar system by $\sim \$ 1 / \mathrm{kWh}$

( (THAX

On-board Assessment Analysis Design Assumptions - Sensitivity Parameters

We used sensitivity analysis to account for design assumptions that are either not very well established or could change significantly in the near future.

\begin{tabular}{|l|c|c|c|l|}
\hline \multicolumn{1}{|c|}{ Design Parameter } & Low & Base & High & \multicolumn{1}{|c|}{ High/Low Basis/Comment } \\
\hline Safety factor & 1.80 & 2.25 & 3.00 & $\begin{array}{l}\text { Based on discussions with Quantum and } \\
\text { Dynatek (2005) }\end{array}$ \\
\hline $\begin{array}{l}\text { Composite tensile } \\
\text { strength, MPa }\end{array}$ & 2,295 & 2,550 & 2,940 & $\begin{array}{l}\text { Low } 10 \% \text { below base case; high assumes } \\
60 \% \text { of fiber strength based on fiber volume } \\
\text { fraction }\end{array}$ \\
\hline $\begin{array}{l}\text { Translation } \\
\text { strength factor } \\
\text { (350 / 700-bar) }\end{array}$ & $0.78 / 0.55$ & $\begin{array}{l}0.825 / \\
0.80\end{array}$ & $0.90 / 0.82$ & $\begin{array}{l}\text { Based on ANL discussions with Quantum } \\
\text { and other developers (2009) }\end{array}$ \\
\hline $\begin{array}{l}\text { Type IV Tank liner } \\
\text { thickness, mm }\end{array}$ & 4.0 & 5.0 & 6.5 & Based on discussions with developers \\
\hline $\begin{array}{l}\text { Type III Tank liner } \\
\text { thickness, mm } \\
\text { (350 / 700-bar) }\end{array}$ & $5.9 / 9.7$ & $7.4 / 12.1$ & $9.6 / 15.7$ & $\begin{array}{l}\text { Low 80\% below base case; high 30\% above } \\
\text { the base case }\end{array}$ \\
\hline $\begin{array}{l}\text { Balance of plant } \\
\text { part count } \\
\text { (Dual tank only) }\end{array}$ & $1 \mathrm{X}$ & $1 \mathrm{X}$ & $\begin{array}{l}\text { Base and low case assumes that both tanks } \\
\text { in the dual tank system use a single balance } \\
\text { of plant; high case assumes that the part } \\
\text { count is doubled. }\end{array}$ \\
\hline
\end{tabular}


On-board Assessment Analysis BOP Costs-Base Cases

The base case cost projections for the major BOP components were estimated assuming high-volume (i.e., 500,000 units/yr) production.

\begin{tabular}{|l|c|c|l|}
\hline $\begin{array}{c}\text { Purchased } \\
\text { Component Cost } \\
\text { Est. (\$ per unit) }\end{array}$ & $\begin{array}{c}350 \text {-bar } \\
\text { Base Case }\end{array}$ & $\begin{array}{r}700 \text {-bar } \\
\text { Base Case }\end{array}$ & \multicolumn{1}{c|}{ Comments/Basis } \\
\hline Pressure regulator & $\$ 160$ & $\$ 200$ & $\begin{array}{l}\text { Industry feedback validated with discussion with Emerson } \\
\text { Process Management/Tescom/Northeast Engineering (2009) } \\
\text { and DFMA® cost modeling software }\end{array}$ \\
\hline $\begin{array}{l}\text { Solenoid Control } \\
\text { valves (3) }\end{array}$ & $\$ 186$ & $\$ 233$ & $\begin{array}{l}\text { Industry feedback validated with quotes and discussion with } \\
\text { Pearse-Bertram for Circle Seal solenoid control valve (2009) }\end{array}$ \\
\hline Fill tube/port & $\$ 50$ & $\$ 63$ & $\begin{array}{l}\text { Industry feedback; quick connect capable of high pressures } \\
\text { without leaks and accepting signals from the nozzle at the } \\
\text { fueling station to open or close }\end{array}$ \\
\hline $\begin{array}{l}\text { Pressure } \\
\text { transducer }\end{array}$ & $\$ 30$ & $\$ 38$ & $\begin{array}{l}\text { Industry feedback validated with quotes and discussion with } \\
\text { Taber Industries (2009) }\end{array}$ \\
\hline Pressure gauge & $\$ 17$ & $\$ 17$ & $\begin{array}{l}\text { Based on quotes from Emerson Process Management/ } \\
\text { Tescom/ Northeast Engineering (2009) }\end{array}$ \\
\hline $\begin{array}{l}\text { Boss and plug (in } \\
\text { tank) }\end{array}$ & $\$ 15$ & $\$ 19$ & $\begin{array}{l}\text { Based on price estimate from tank developers (2009), } \\
\text { validated with Al raw material price marked up for processing }\end{array}$ \\
\hline Other BoP & $\$ 58$ & $\$ 68$ & $\begin{array}{l}\text { Includes manual service vent valves (2), check valves (2), } \\
\text { rupture disks (2), pipe assembly, bracket assembly, pressure } \\
\text { relief devices (2), and gas temperature sensor. }\end{array}$ \\
\hline
\end{tabular}

${ }^{1}$ Note: Additional purchased component cost projections and a comparison to last year's assumptions are presented in the Appendix.

On-board Assessment Analysis BOP Costs-Sensitivity Parameters

To account for the inherent uncertainty in the BOP cost projections, we developed "low" and "high" cost estimates as inputs to the sensitivity analysis.

\begin{tabular}{|l|c|c|c|l|}
\hline $\begin{array}{c}\text { Purchased } \\
\text { Component Cost } \\
\text { Est. (\$ per unit) }\end{array}$ & $\begin{array}{c}\text { Low } \\
(350 / 700- \\
\text { bar) }\end{array}$ & $\begin{array}{c}\text { Base } \\
\text { Cases } \\
(350 / 700- \\
\text { bar) }\end{array}$ & $\begin{array}{c}\text { High } \\
(350 / 700- \\
\text { bar) }\end{array}$ & High/Low Comments/Basis \\
\hline Pressure regulator & $\$ 80 / \$ 100$ & $\begin{array}{c}\$ 160 / \\
\$ 200\end{array}$ & $\begin{array}{c}\$ 360 / \\
\$ 450\end{array}$ & $\begin{array}{l}\text { Low and high based on discussions with tank } \\
\text { developers and vendors }(2009)\end{array}$ \\
\hline Control valve & $\$ 93 / \$ 117$ & $\begin{array}{c}\$ 186 / \\
\$ 233\end{array}$ & $\begin{array}{c}\$ 372 / \\
\$ 466\end{array}$ & $\begin{array}{l}\text { Low and high are half and double the base } \\
\text { cases, respectively }\end{array}$ \\
\hline Fill tube/port & $\$ 25 / \$ 32$ & $\$ 50 / \$ 63$ & $\begin{array}{c}\$ 100 / \\
\$ 125\end{array}$ & $\begin{array}{l}\text { Low and high are half and double the base } \\
\text { cases, respectively }\end{array}$ \\
\hline $\begin{array}{l}\text { Pressure } \\
\text { transducer }\end{array}$ & $\$ 15 / \$ 19$ & $\$ 30 / \$ 38$ & $\$ 60 / \$ 76$ & $\begin{array}{l}\text { Low and high are half and double the base } \\
\text { cases, respectively }\end{array}$ \\
\hline Pressure gauge & $\$ 9 / \$ 9$ & $\$ 17 / \$ 17$ & $\$ 34 / \$ 34$ & $\begin{array}{l}\text { Low and high are half and double the base } \\
\text { cases, respectively }\end{array}$ \\
\hline $\begin{array}{l}\text { Boss and plug (in } \\
\text { tank) }\end{array}$ & $\$ 12 / \$ 15$ & $\$ 15 / \$ 19$ & $\begin{array}{c}\$ 100 / \\
\$ 125\end{array}$ & $\begin{array}{l}\text { Low is } 75 \% \text { of base case; high assumes more } \\
\text { complex processing requirement }\end{array}$ \\
\hline
\end{tabular}


On-board Assessment Analysis Raw Material Prices-Base Cases

We based the cost of purchased raw materials on raw material databases and discussions with suppliers and adjusted to $2005 \$$.

\begin{tabular}{|c|c|c|}
\hline $\begin{array}{l}\text { Raw Material Cost } \\
\text { Estimates, } 2005 \$ / \mathrm{kg}\end{array}$ & Base Cases & Comment/Basis \\
\hline Hydrogen & 3.0 & Consistent with $\mathrm{DOE} \mathrm{H}_{2}$ delivery target \\
\hline HDPE liner & 1.6 & Plastics Technology (2008), deflated to $2005 \$$ \\
\hline Aluminum (6061-T6) & 9.6 & Bulk price from Alcoa (2009), deflated to $2005 \$$ \\
\hline $\begin{array}{l}\text { Carbon fiber (T700S) } \\
\text { prepreg }\end{array}$ & 36.6 & $\begin{array}{l}\text { Discussion w/ Toray }(2007) \text { re: T700S fiber }(\$ 10-\$ 16 / \mathrm{lb} \text {, } \\
\$ 13 / \mathrm{lb} \text { base case in } 2005 \$) ; 1.27 \text { prepreg/fiber ratio (Du } \\
\text { Vall 2001) }\end{array}$ \\
\hline Glass fiber prepreg & 4.7 & $\begin{array}{l}\text { Discussions with AGY (2007) for non-structural fiber } \\
\text { glass, deflated to } 2005 \$\end{array}$ \\
\hline Foam end caps & 6.4 & Plastics Technology (2008), deflated to $2005 \$$ \\
\hline Stainless steel (304) & 4.7 & $\begin{array}{l}\text { Average monthly costs from Sep '06 - Aug '07 (MEPS } \\
\text { International 2007) deflated to } 2005 \$ \text { s by } \sim 6 \% / y r\end{array}$ \\
\hline Standard steel & 1.0 & $\begin{array}{l}\text { Estimate based on monthly cost range for } 2008-2009 \\
\text { (MEPS International 2009), , deflated to } 2005 \$\end{array}$ \\
\hline
\end{tabular}

Note: All prices reflect material costs in constant $2005 \$$

On-board Assessment Analysis Raw Material Prices-Sensitivity Parameters

We also developed low and high estimates for the cost of purchased raw materials as inputs to the sensitivity analysis.

\begin{tabular}{|l|c|c|c|l|}
\hline $\begin{array}{l}\text { Raw Material Cost } \\
\text { Estimates, \$/kg }\end{array}$ & Low & $\begin{array}{c}\text { Base } \\
\text { Cases }\end{array}$ & High & \multicolumn{1}{|c|}{ High/Low Comments/Basis } \\
\hline Hydrogen & 1.5 & 3.0 & 6.0 & Low and high are half and double the base cases \\
\hline HDPE liner & 0.8 & 1.6 & 3.2 & Low and high are half and double the base cases \\
\hline Aluminum (6061-T6) & 4.8 & 9.6 & 19.2 & Low and high are half and double the base cases \\
\hline $\begin{array}{l}\text { Carbon fiber (T700S) } \\
\text { prepreg }\end{array}$ & 18.5 & 36.6 & 44.9 & $\begin{array}{l}\text { Low assumes } 68 \% \text { fiber (wt.) at } \$ 10 / \mathrm{lb} \text { and } 32 \% \\
\text { Toray }(2007) \text { re: T700S fiber at } \$ 16 / \mathrm{lb} \text { and } 1.27 \\
\text { prepreg/fiber ratio (Du Vall 2001) }\end{array}$ \\
\hline Glass fiber prepreg & 2.9 & 4.7 & 9.4 & Low and high are $60 \%$ and double the base cases \\
\hline Foam end caps & 3.5 & 6.4 & 14 & Low and high are half and double the base cases \\
\hline Stainless steel (304) & 2.4 & 4.7 & 9.4 & Low and high are half and double the base cases \\
\hline Standard steel & 0.5 & 1.0 & 2.0 & Low and high are half and double the base cases \\
\hline
\end{tabular}

Carbon fiber is already produced at very high-volumes for the Aerospace industry, so it isn't expected to become significantly cheaper in the near term. ${ }^{1}$

a Weighted raw material costs would be more relevant for a wet winding process, which may also alter fiber winding processing costs. However, there are DOE programs that are looking at ways to significantly reduce carbon fiber costs (e.g., Abdallah 2004). 
On-board Assessment Results Processing Cost Estimates-Base Cases

The costs of key processing steps are estimated from capital equipment, labor, and other operating costs assuming a high level of automation.

\begin{tabular}{|l|c|c|}
\hline $\begin{array}{c}\text { Key Processing Steps - Compressed Gas } \\
\text { Tanks }\end{array}$ & $\begin{array}{c}\text { 350-bar Type IV } \\
\text { Single Tank System }\end{array}$ & $\begin{array}{c}\text { 700-bar Type IV } \\
\text { Single Tank System }\end{array}$ \\
\hline Liner Fabrication & $\$ 11$ & $\$ 10$ \\
\hline Carbon Fiber Winding Process & $\$ 83$ & $\$ 102$ \\
\hline Glass Fiber Winding Process & $\$ 7$ & $\$ 6$ \\
\hline Foam End Caps & $\$ 2$ & $\$ 1$ \\
\hline Assembly and Inspection & $\$ 36$ & $\$ 36$ \\
\hline Total & $\$ 138$ & $\$ 156$ \\
\hline
\end{tabular}

- The processing costs for dual tank Type IV systems are \$162 and \$180 for 350 and 700-bar systems, respectively. This includes a small increase in carbon fiber and larger increases in liner fabrication and glass winding costs. ${ }^{1}$

- The processing costs for single tank Type III systems are $\$ 141$ and $\$ 165$ for 350 and 700-bar systems, respectively - a small increase compared to Type IV systems ${ }^{1}$

The higher, 700 bar pressure requirement, primarily increases the cost of the carbon fiber winding process.

$((\sqrt{1})$

${ }^{1}$ A detailed breakdown of dual tank and Type III processing costs is included in the appendix

On-board Assessment Results Material vs.Process Cost-Base Cases

Processing cost makes up only $5 \%$ of the total Type IV system cost due to the assumed high production volumes and large number of purchased components.

\begin{tabular}{|l|c|c|c|c|c|c|}
\hline \multirow{2}{*}{$\begin{array}{c}\text { On-board System Cost } \\
\text { Breakout - Compressed Gas }\end{array}$} & \multicolumn{3}{|c|}{ Type IV 350-bar Base Case } & \multicolumn{3}{c|}{ Type IV 700-bar Base Case } \\
\cline { 2 - 7 } & $\begin{array}{c}\text { Material, } \\
\$\end{array}$ & $\begin{array}{c}\text { Processing, } \\
\$\end{array}$ & $\begin{array}{c}\text { Processing } \\
\text { Fraction }\end{array}$ & $\begin{array}{c}\text { Material, } \\
\$\end{array}$ & $\begin{array}{c}\text { Processing, } \\
\$\end{array}$ & $\begin{array}{c}\text { Processing } \\
\text { Fraction }\end{array}$ \\
\hline Hydrogen & $\$ 18$ & (purchased) & - & $\$ 18$ & (purchased) & - \\
\hline Compressed Vessel & $\$ 2,193$ & $\$ 102$ & $4 \%$ & $\$ 2,681$ & $\$ 119$ & $4 \%$ \\
$\quad$ Liner \& Fittings & $\$ 20$ & $\$ 11$ & $34 \%$ & $\$ 14$ & $\$ 10$ & $43 \%$ \\
Carbon Fiber Layer & $\$ 2,111$ & $\$ 83$ & $4 \%$ & $\$ 2,619$ & $\$ 102$ & $4 \%$ \\
Glass Fiber Layer & $\$ 30$ & $\$ 7$ & $18 \%$ & $\$ 23$ & $\$ 6$ & $21 \%$ \\
Foam & $\$ 32$ & $\$ 2$ & $5 \%$ & $\$ 25$ & $\$ 1$ & $5 \%$ \\
\hline Regulator & $\$ 160$ & (purchased) & - & $\$ 200$ & (purchased) & - \\
\hline Valves & $\$ 226$ & (purchased) & - & $\$ 282$ & (purchased) & - \\
\hline Other BOP & $\$ 130$ & (purchased) & - & $\$ 155$ & (purchased) & - \\
\hline Final Assembly \& Inspection & - & $\$ 36$ & - & - & $\$ 36$ & - \\
\hline Total Factory Cost & $\$ 2,727$ & $\$ 138$ & $\mathbf{5} \%$ & $\$ 3,334$ & $\$ 156$ & $\mathbf{4} \%$ \\
\hline
\end{tabular}

A similar ratio of material to processing cost is seen for Type III and dual tank systems. 
On-board Assessment Results Cost Breakout-Type IV, Single Tank Base Cases

The carbon fiber composite layer accounts for about $75 \%$ and $80 \%$ of the single tank Type IV 350-bar and 700-bar system costs, respectively.
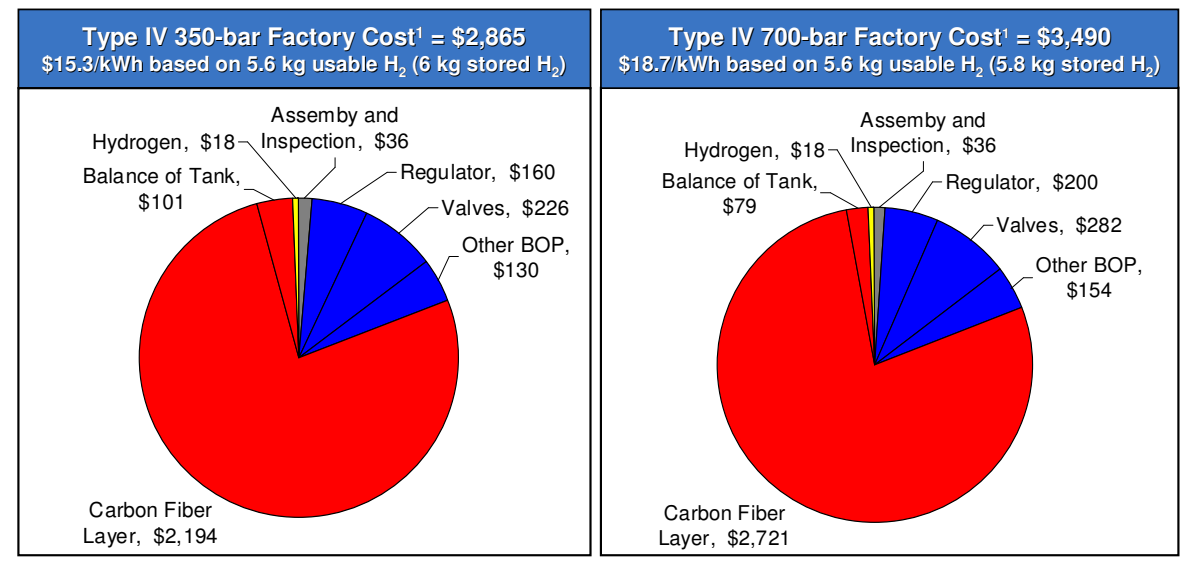

${ }_{1}$ Cost estimate in 2005 USD. Includes processing costs.

These costs, adjusted for progress ratios of 85 to $90 \%$, are consistent with industry factory cost projections for similar tanks at lower production volumes. Details are presented in the Appendix

( (TIAX MK/092010/00268 TIAX On-Board Comp Cost - Sept 2010.ppt

On-board Assessment Results Cost Breakout - Sensitivity Analysis for Type IV, single tank systems

Single variable sensitivity analysis shows that carbon fiber cost and safety factor assumptions have the biggest impact on our system cost projections.

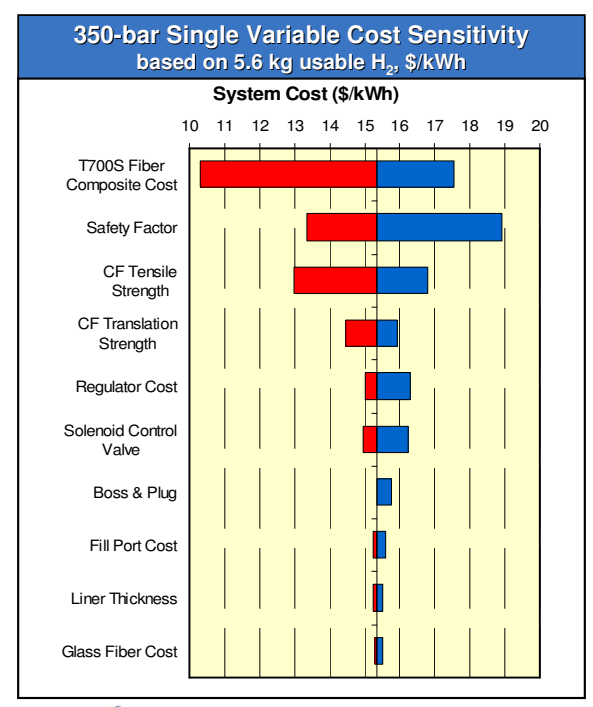

(CITX

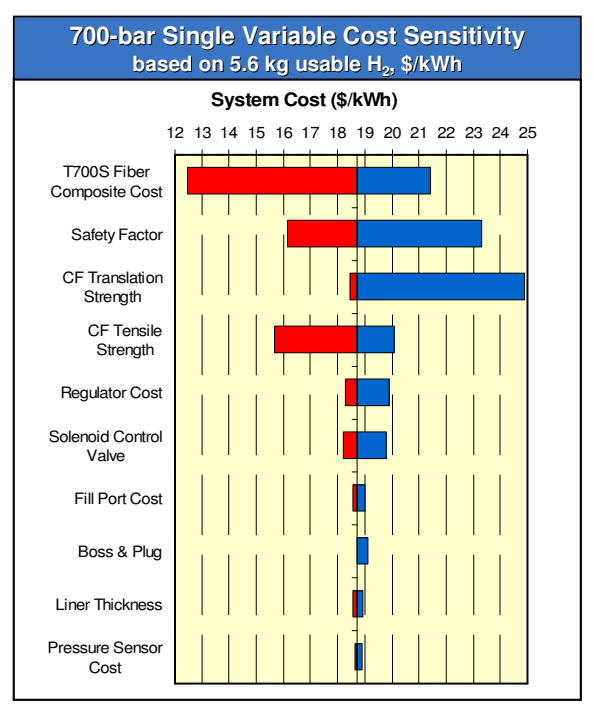

MK/092010/D0268 TAAX On-Board Comp Cost- Sept 2010. ppt 
On-board Assessment Results Cost Breakout-Sensitivity Analysis for Single Tank, Type IV systems

Monte Carlo simulations project that the factory cost is likely to be between $\$ 10.6-19.7 / \mathrm{kWh}$ for 350 -bar and $\$ 13.5-27.2 / \mathrm{kWh}$ for 700 -bar tank systems. ${ }^{1}$
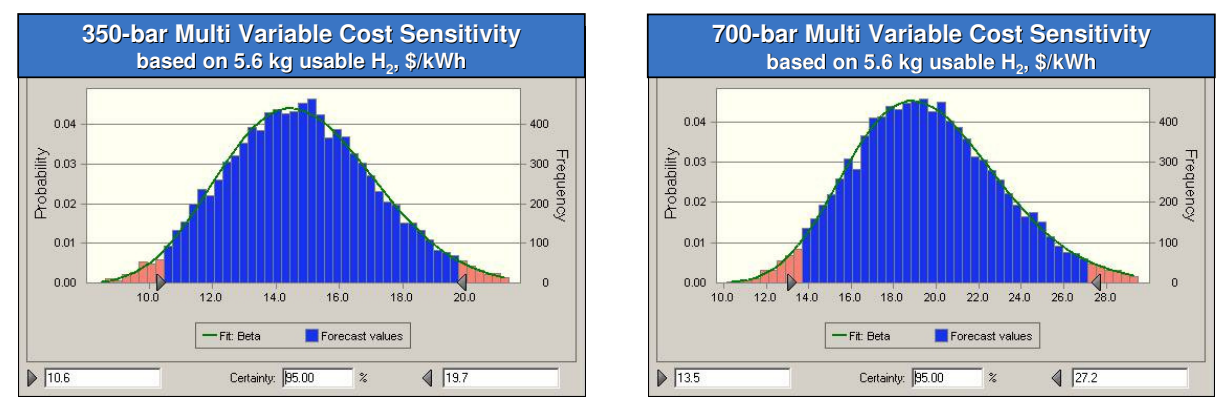

\begin{tabular}{|l|c|}
\hline Base Case & 15.4 \\
\hline Mean & 14.8 \\
\hline Standard Deviation & 2.3 \\
\hline "Low" Case" & 10.60 \\
\hline "High" Case" $^{1}$ & 19.7 \\
\hline
\end{tabular}

\begin{tabular}{|l|c|}
\hline Base Case & 18.7 \\
\hline Mean & 19.7 \\
\hline Standard Deviation & 3.5 \\
\hline "Low" Case' & 13.5 \\
\hline "High" Case" & 27.2 \\
\hline
\end{tabular}

${ }^{1}$ The ranges shown here reflect the $95 \%$ confidence interval based on the probability distribution.

On-board Assessment Results Comparison to Previous Results - Type IV, Single Tank Base Cases

350 and 700 -bar system cost, weight and volume decreased (grav. and vol. capacities increased) due to revised assumptions compared to 2008.

- The tank safety factor was applied to the nominal tank pressure rather than max. filling over pressure and most BOP costs were reduced based on industry feedback

- Changing the tank end dome shape based on ANL's latest performance analysis and increasing the translation strength of the 700 bar system also resulted in decreases to cost, weight, and volume

- Reducing the carbon fiber composite tensile strength partially offset the above adjustments

- Reduced balance of plant unit costs, but increased BOP part count resulted in net cost reductions.

- Other changes to the tank design had a modest impact on the results (e.g., increasing safety factor, decreasing diameter, changing minimum pressure)

\begin{tabular}{|l|c|c|c|c|}
\hline \multirow{2}{*}{$\begin{array}{c}\text { 2010 Updated Results } \\
\text { Compared to 2008 AMR } \\
\text { Results }\end{array}$} & \multicolumn{2}{|c|}{ 350-bar Base Case } & \multicolumn{2}{c|}{ 700-bar Base Case } \\
\cline { 2 - 5 } & $\mathbf{2 0 1 0 / 2 0 0 8}$ & $\%$ Change & $\mathbf{2 0 1 0 / 2 0 0 8}$ & $\%$ Change \\
\hline Gravimetric Capacity, wt\% & $5.5 / 5.3$ & $+4 \%$ & $5.0 / 4.0$ & $+25 \%$ \\
\hline Volumetric Capacity, g H $\mathbf{2} \mathbf{L}$ & $17.5 / 17.0$ & $+3 \%$ & $26.2 / 23.0$ & $+14 \%$ \\
\hline System Cost, \$/kWh & $15.4 / 17.1$ & $-14 \%$ & $18.7 / 26.7$ & $-30 \%$ \\
\hline
\end{tabular}


On-board Assessment Results Summary of Alternate System Configurations

\section{Type III and dual tank systems both show a small increase in system} weight and cost relative to single tank, type IV systems.

\begin{tabular}{|c|c|c|c|}
\hline Case & $\begin{array}{c}\text { Cost } \\
(\mathbf{\$} / \mathbf{k W h})\end{array}$ & Volume (L) & Weight $(\mathbf{k g})$ \\
\hline 350-Bar base, type IV, 1 tank & 15.3 & 320 & 102 \\
\hline 700-Bar base, type IV, 1 tank & 18.7 & 213 & 112 \\
\hline 350-Bar base, type IV, 2 tank & 15.7 & 326 & 110 \\
\hline 700-Bar base, type IV, 2 tank & 19.1 & 219 & 118 \\
\hline 350-Bar base, type III, 1 tank & 16.5 & 321 & 134 \\
\hline 700-Bar base, type III, 1 tank & 21.0 & 224 & 158 \\
\hline 350-Bar base, type III, 2 tank & 16.8 & 324 & 137 \\
\hline 700-Bar base, type III, 2 tank & 21.2 & 226 & 161 \\
\hline
\end{tabular}

- Type III designs are projected to increase factory costs by $\$ 200$ to $\$ 400$ and weight by $35-45 \mathrm{~kg}$.

$>$ The reduction in carbon fiber enabled by the load-bearing qualities of a Type III aluminum liner is more than offset by its higher cost, weight, and thickness compared to the Type IV HDPE liner.

- Two-tank systems are projected to increase factory costs by less than $\$ 100$

$>$ The pressure vessel for the single tank system has a lower surface area-to-volume ratio than the dual tank system, but this advantage is largely offset by the fact that the single tank pressure vessel requires thicker vessel walls.

> We have assumed that the dual tank system's balance of plant is similar to that of the single tank system. Sensitivity analysis is used to assess the cost impact of doubling the BOP part count.

( (IIAX)

On-board Assessment Results Factory Cost Comparison-Type III tanks and dual tank systems

For each configuration examined, carbon fiber material cost dominates the total system cost.

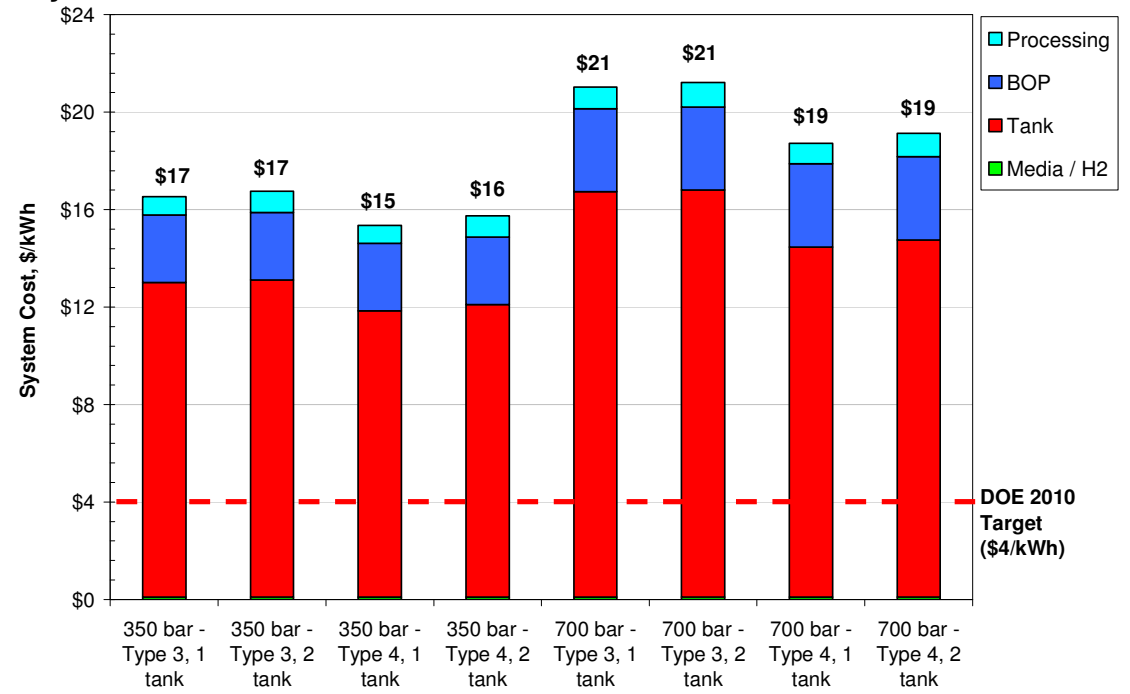


On-board Assessment Results Cost Breakout-Dual Tank Systems

The dual tank systems have a slightly higher cost than single tank systems due to increases in the cost of the pressure vessel.

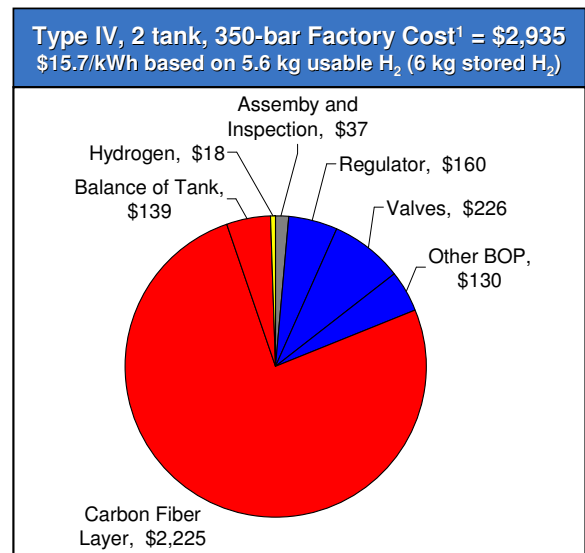

Type IV, 2 tank, 700-bar Factory Cost ${ }^{1}=\$ 3,569$ $\$ 19.1 / \mathrm{kWh}$ based on $5.6 \mathrm{~kg}$ usable $\mathrm{H}_{2}\left(5.8 \mathrm{~kg}\right.$ stored $\left.\mathrm{H}_{2}\right)$

Layer, $\$ 2,225$

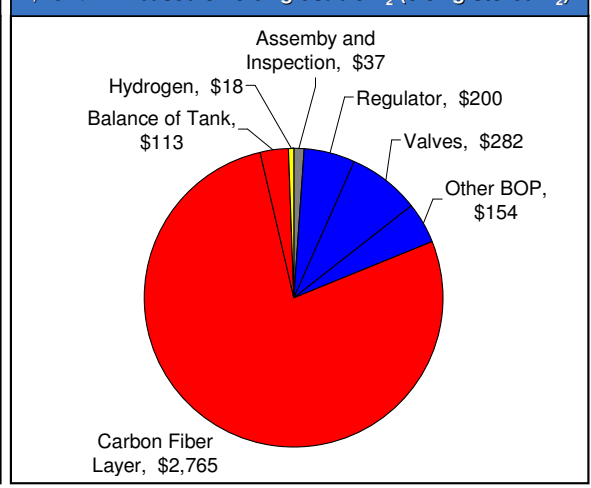

1 Cost estimate in 2005 USD. Includes processing costs.
Note: For reference, the Type IV 350 -bar single tank system costs $\$ 2,865$; the Type IV 700 -bar single tank systems costs $\$ 3,490$.

The pressure vessel cost increase includes $<5 \%$ increase in material cost and a $20-25 \%$ increase in the tank processing cost.

On-board Assessment Results Cost Breakout-Type III, Single Tank

The carbon fiber composite layer accounts for a smaller fraction of the Type III system cost compared to the Type IV system, but the Type III aluminum liner adds significant additional expense.

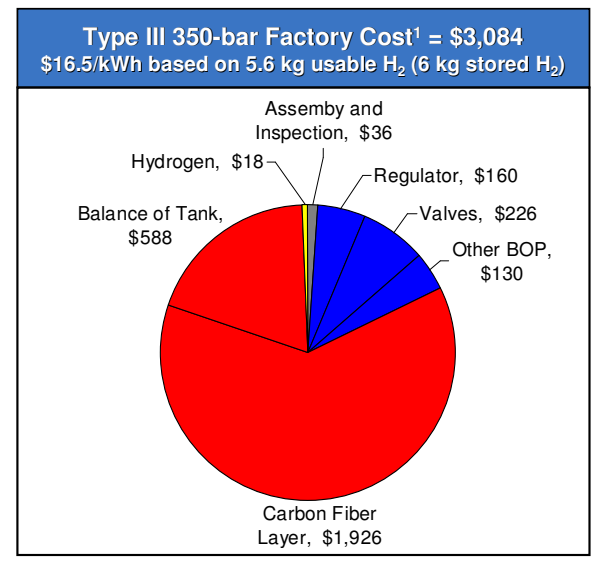

Type III 700-bar Factory Cost ${ }^{1}=\$ 3,921$ $\$ 21.0 / \mathrm{kWh}$ based on $5.6 \mathrm{~kg}$ usable $\mathrm{H}_{2}\left(5.8 \mathrm{~kg}\right.$ stored $\left.\mathrm{H}_{2}\right)$

${ }^{1}$ Cost estimate in 2005 USD. Includes processing costs.

Note: For reference, the Type IV 350 -bar single tank system costs $\$ 2,865$; the Type IV 700 -bar single tank systems costs $\$ 3,490$. 
On-board Assessment Results Cost Breakout - Sensitivity Analysis for Dual tank systems

For dual tank systems, single-variable sensitivity analysis was used to characterize the cost impact of doubling the balance-of-plant part count
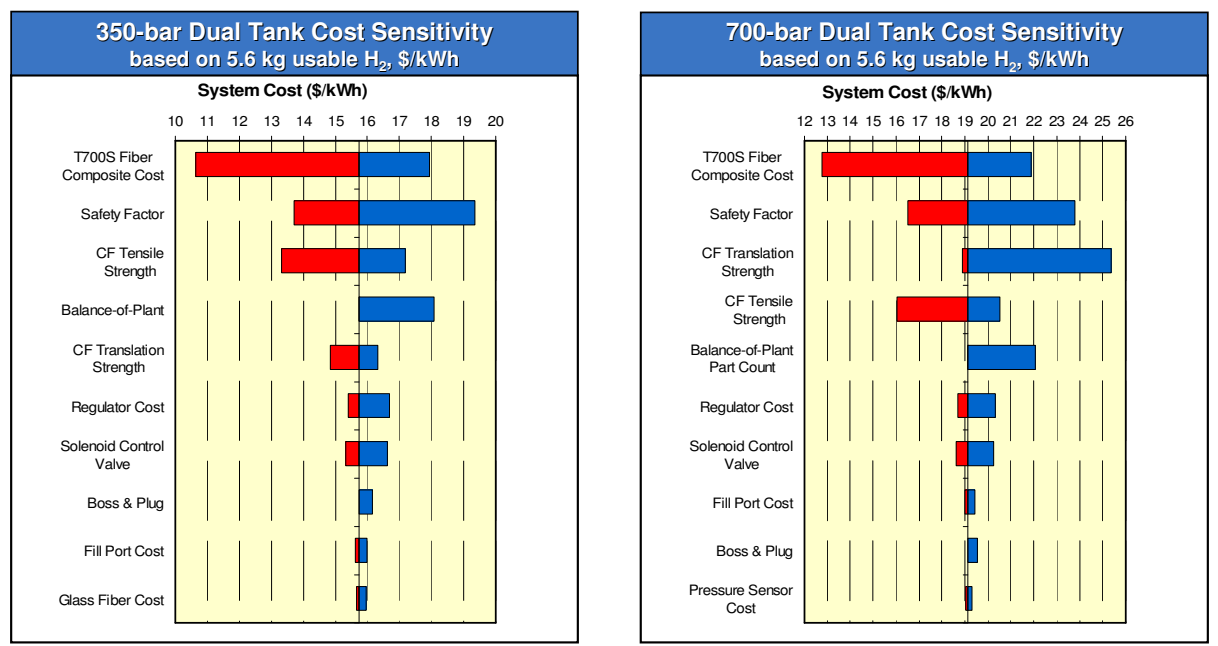

As shown, a second BOP system increases the cost of a dual tank system by $\$ 2.4$ and $\$ 3.0 / \mathrm{kWh}$ for 350 -bar and 700 -bar systems, respectively

( (TIRX

On-board Assessment Results Cost Breakout - Sensitivity Analysis for Dual Tank Systems

Monte Carlo simulations of dual tank systems project that the factory cost is likely to be between $\$ 11.6-21.4 / \mathrm{kWh}$ for $350-$ bar and $\$ 14.9-29.6 / \mathrm{kWh}$ for $700-$ bar tank systems. ${ }^{1}$
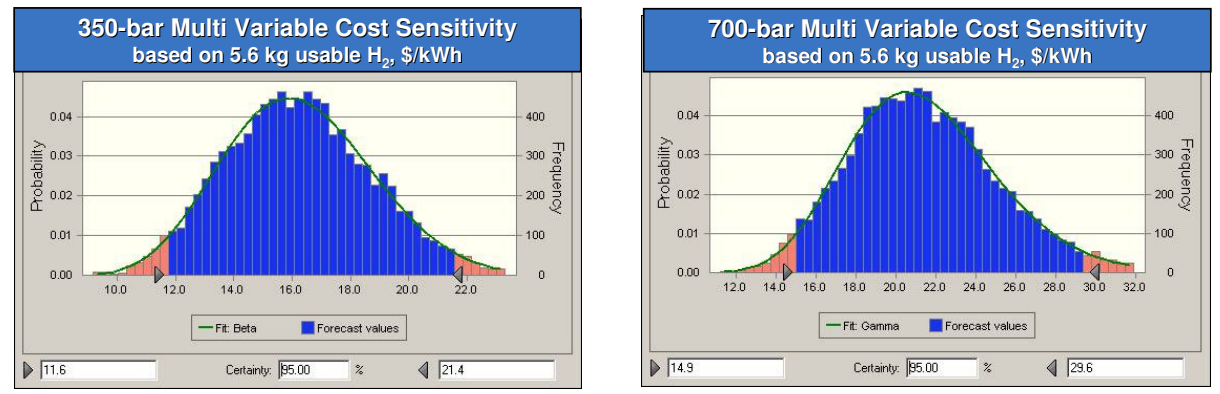

\begin{tabular}{|l|c|}
\hline Base Case & 15.7 \\
\hline Mean & 16.2 \\
\hline Standard Deviation & 2.5 \\
\hline "Low" Case' & 11.6 \\
\hline "High" Case1 & 21.4 \\
\hline
\end{tabular}

\begin{tabular}{|l|c|}
\hline Base Case & 19.1 \\
\hline Mean & 21.4 \\
\hline Standard Deviation & 3.8 \\
\hline "Low" Case' & 14.9 \\
\hline "High" Case" & 29.6 \\
\hline
\end{tabular}

Due to uncertainty over the BOP design, the $95 \%$ confidence interval is shifted higher relative to the base case than that projected for the single tank system.

${ }^{1}$ The ranges shown here reflect the $95 \%$ confidence interval based on the probability distribution. 
On-board Assessment Results Cost Breakout - Sensitivity Analysis for Type III Systems

For Type III systems, the cost and thickness of the aluminum liner have a strong effect on system cost

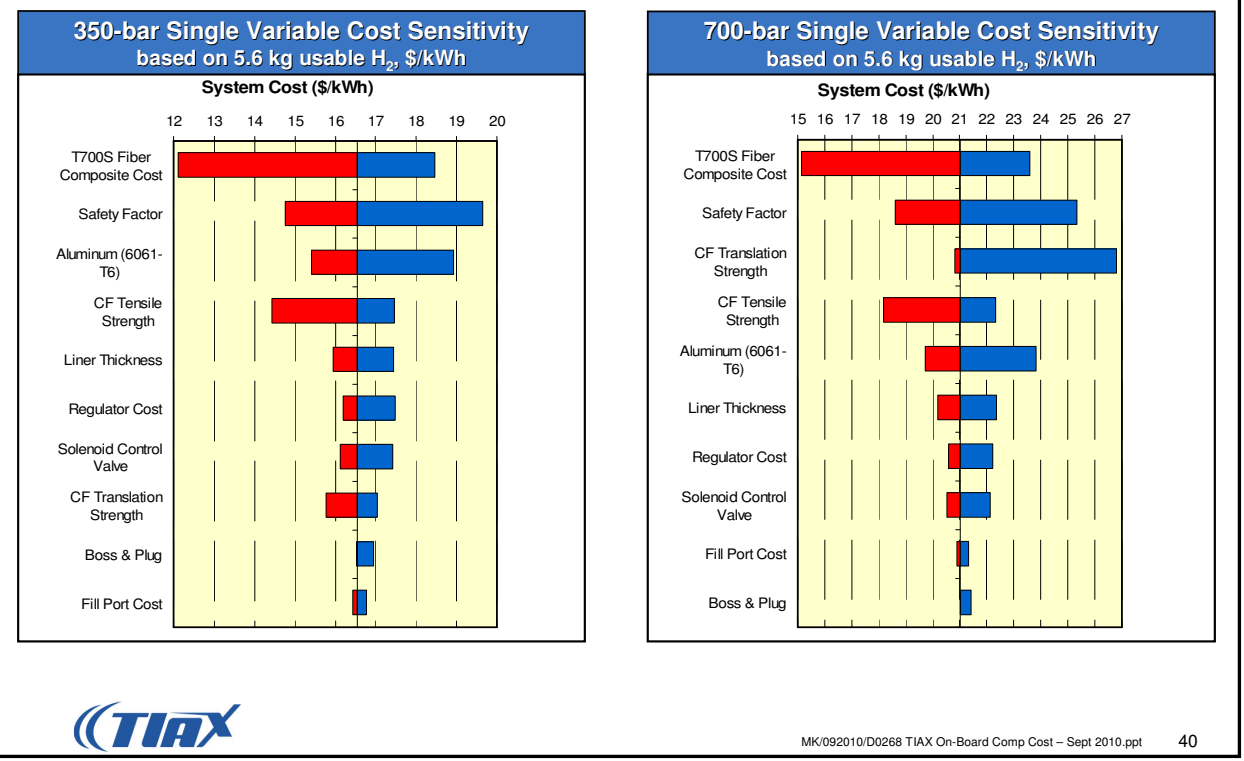

On-board Assessment Results Cost Breakout - Sensitivity Analysis for Type III Systems

Monte Carlo simulations project that the factory cost of Type III systems is likely to be between $\$ 12.5-21.2 / \mathrm{kWh}$ for $350-$ bar and $\$ 16.5-30.3 / \mathrm{kWh}$ for $700-$ bar tank systems. ${ }^{1}$
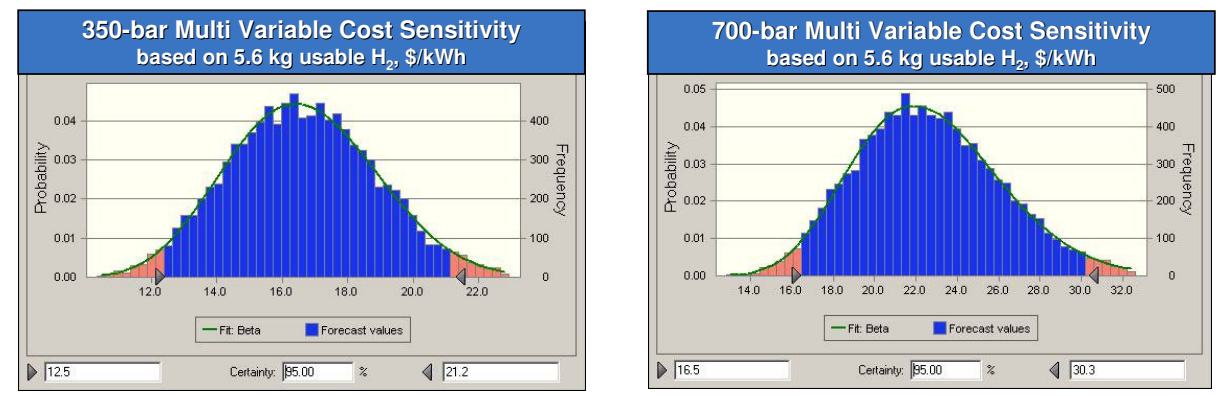

\begin{tabular}{|l|c|}
\hline Base Case & 15.7 \\
\hline Mean & 16.6 \\
\hline Standard Deviation & 2.2 \\
\hline "Low" Case' & 12.5 \\
\hline "High" Case1 & 21.1 \\
\hline
\end{tabular}

\begin{tabular}{|l|c|}
\hline Base Case & 21.0 \\
\hline Mean & 22.7 \\
\hline Standard Deviation & 3.6 \\
\hline "Low" Case1 & 16.5 \\
\hline "High" Case" & 30.3 \\
\hline
\end{tabular}

${ }^{1}$ The ranges shown here reflect the $95 \%$ confidence interval based on the probability distribution. 
On-board Assessment Results Dual Tank and Type III Systems

\section{Conclusions - Dual Tank and Type III Systems}

- Cost and performance projections indicate that Type III tanks will be more expensive and heavier than Type IV tanks:

$>$ Type III tanks require less carbon fiber than Type IV tanks, but the cost and weight of the aluminum liner are significantly higher than those of the HDPE liner.

> Carbon fiber costs account for 60 to $70 \%$ of the cost of Type III tanks, compared to 75 to $80 \%$ of the cost of Type IV tanks

- Dual tank systems come at a small cost increment ( $\$ 0.3$ to $\$ 0.5 / \mathrm{kWh}$ ) to single tank systems, and have very little effect on system size and weight.

$>$ Projections show a slight $(<5 \%)$ increase in material costs: Single tank pressure vessels have a lower total surface area, but require thicker walls

$>$ Processing costs are 20 to $25 \%$ higher, but these represent less than $5 \%$ of the total system cost

$>$ If dual tank systems are designed to use a separate set of balance-of-plant components for each tank, the cost increase of a dual tank system is $\$ 2.7$ to $\$ 3.4 / \mathrm{kWh}$ compared to a single tank system.

On-board Assessment Results Factory Cost Comparison-Base Cases

The base case Type IV compressed systems' high-volume costs are projected to be 4-5 times higher than the current DOE 2010 cost target of $\$ 4 / \mathrm{kWh}$.

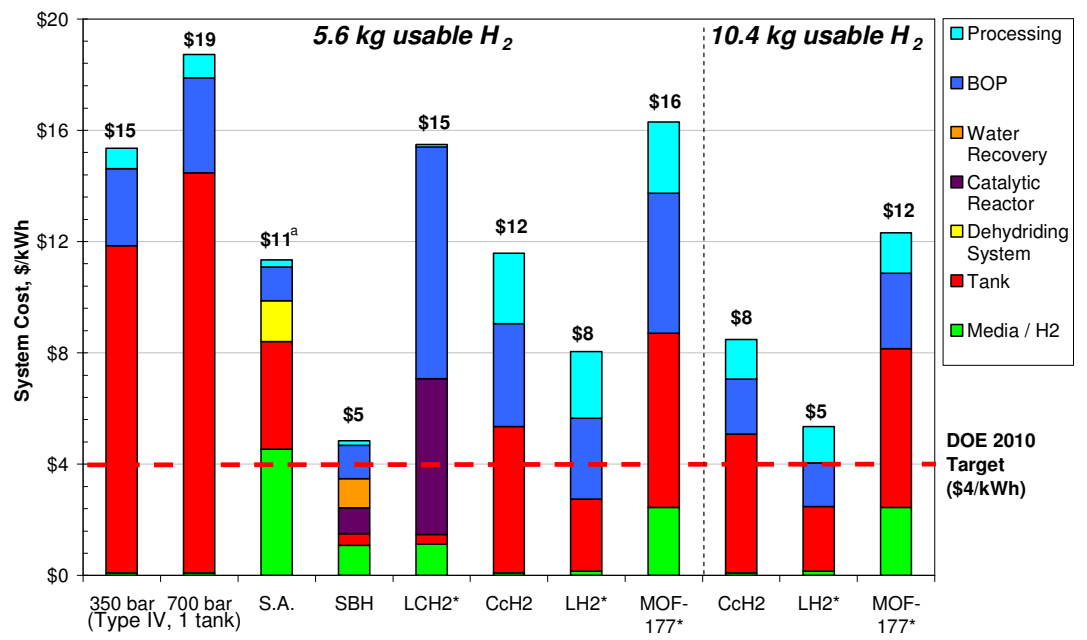

Note: not all hydrogen storage systems shown are at the same stage of development, and each would have different on-board performance characteristics. a The sodium alanate system requires high temp. waste heat for hydrogen desorption, otherwise the usable hydrogen capacity would be reduced. Indicates a preliminary cost assessment, to be reviewed prior to contract completion. 


\begin{tabular}{|l|l|}
\hline 1 & Executive Summary \\
\hline 2 & On-board Assessment \\
\hline 3 & Off-board Assessment \\
\hline & Approach \\
\hline & Analysis \\
\hline 4 & Results \\
\hline 4 & Conclusions \\
\hline A & Appendix \\
\hline
\end{tabular}

Off-board Assessment Approach Models/Methods

The off-board assessment makes use of existing models to calculate cost and performance for each technology on a consistent basis.

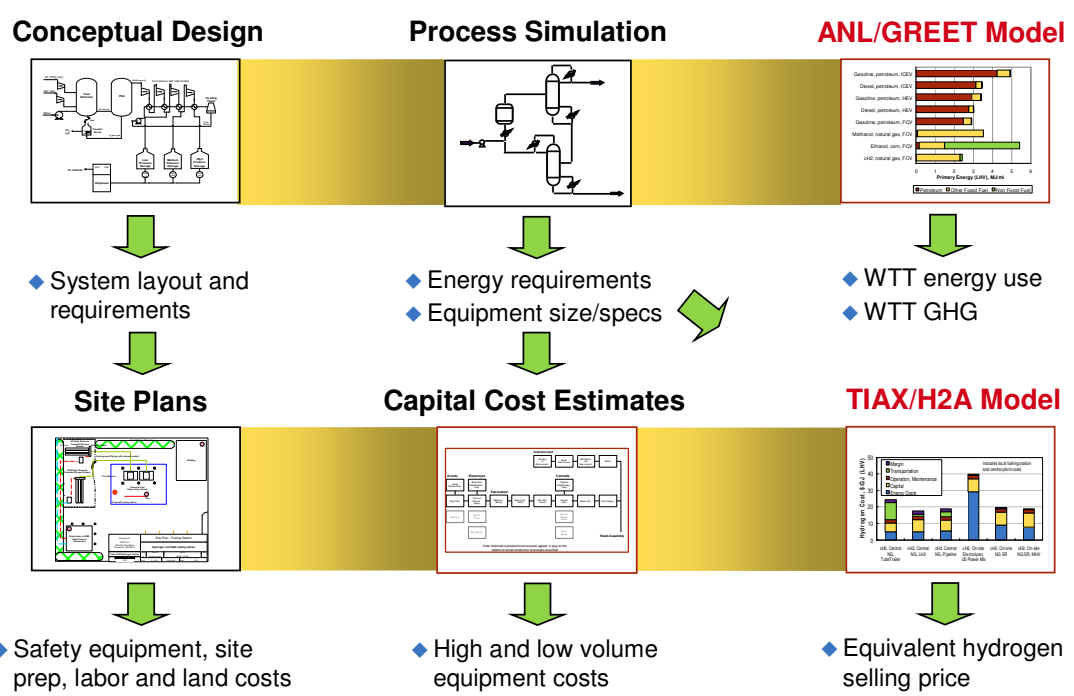


Off-board Assessment Analysis $\mathrm{H} 2 \mathrm{~A} \mathrm{HDSAM}$ Inputs for $\mathrm{CH}_{2}$ and $\mathrm{CCH}_{2}$

Cryo-compressed and compressed (350- and 700-bar) hydrogen off-board cost results were calculated using the base case delivery scenarios in HDSAM v2.06.

\begin{tabular}{|c|c|c|}
\hline HDSAM Delivery Scenario Assumptions & $\begin{array}{c}350 \text { and } 700 \text {-bar } \\
\text { Base Cases }\end{array}$ & $\begin{array}{c}\text { Cryo-compressed } \\
\text { Base Cases } \\
\end{array}$ \\
\hline Hydrogen Market & Urban & Urban \\
\hline Market Penetration & $30 \%$ & $30 \%$ \\
\hline City Selection & $\begin{array}{l}\text { Indianapolis, IN } \\
(\sim 1.2 \mathrm{M} \text { people })\end{array}$ & $\begin{array}{l}\text { Indianapolis, IN } \\
(\sim 1.2 \mathrm{M} \text { people })\end{array}$ \\
\hline Central Plant $\mathrm{H}_{2}$ Production Cost & $\$ 1.50 / \mathrm{kg} \mathrm{H}_{2}$ & $\$ 1.50 / \mathrm{kg} \mathrm{H}_{2}$ \\
\hline Plant Outage/Summer Peak Storage & Geologic & Cryogenic liquid tanks \\
\hline Transmission/Distribution Mode & Compressed gas pipeline & $\begin{array}{l}\mathrm{LH}_{2} \text { tanker trucks } \\
\text { (284 km round trip) }\end{array}$ \\
\hline Transmission/Distribution Capacity & NA & $4,100 \mathrm{~kg} \mathrm{LH}{ }_{2}$ \\
\hline Refueling Station Size & $1,000 \mathrm{~kg} \mathrm{H}_{2} /$ day & $1,000 \mathrm{~kg} \mathrm{H}_{2} /$ day \\
\hline Dispensing Temperature & $\begin{array}{l}350-\text { bar }=\text { ambient }\left(25^{\circ} \mathrm{C}\right) \\
700-\text { bar }=-40^{\circ} \mathrm{C} \text { for fast fill }\end{array}$ & $-253^{\circ} \mathrm{C}$ \\
\hline Dispensing Pressure & $\begin{array}{l}25 \% \text { over-pressure for fast fill } \\
\text { (up to } 438 \text { and } 875 \text { bar } \mathrm{cH}_{2} \text { ) }\end{array}$ & $\begin{array}{l}25 \% \text { over-pressure for fast fill } \\
\text { (up to } 340 \text { bar } \mathrm{LH}_{2} \text { ) }\end{array}$ \\
\hline Hydrogen Losses & $<1 \%$ & $\begin{array}{c}7.5 \%(0.5 \% \text { each from liquefaction, } \\
\text { storage and loading; } 6 \% \text { from } \\
\text { unloading) }\end{array}$ \\
\hline On-board Storage System & $\begin{array}{c}\text { 350-bar and 700-bar compressed } \\
\text { gas }\end{array}$ & $\begin{array}{l}\text { Cryogenic liquid and } 272 \text { bar } \\
\text { compressed gas }\end{array}$ \\
\hline
\end{tabular}

( (IITX)

Off-board Assessment Analysis H2A HDSAM Inputs for SBH

The chemical hydride (i.e., SBH, $\mathrm{LCH}_{2}$ ) off-board cost results were calculated using a modified version of the Delivery Components Carrier Model v34.

- Most financial assumptions are retained from the original H2A Delivery Components Model

- New calculation tabs were added as part of the DOE Delivery Project for novel carriers, resulting in the H2A Delivery Components Carrier Model v34

$>$ Regeneration - calculates material regeneration costs based on capital and operating costs of a central plant and the storage capacity of the material

$>$ Storage Terminal - calculates offsite storage for fresh and spent materials

> Trucking - calculates trucking costs for all novel carriers

> Fueling Station - calculates fueling station costs for onsite novel carrier storage and vehicle fueling

- These new calculation tabs were populated with inputs based on industry and developer feedback specifically for $\mathrm{SBH}(\mathrm{MCell}, \mathrm{R} \& \mathrm{H})$ ) and $\mathrm{LCH}_{2}(\mathrm{APCl})$

$>$ TIAX made initial estimates consistent with $\mathrm{H} 2 \mathrm{~A}$ methodology

> Model and estimates were reviewed with technology developers

$>$ Model inputs and results were updated 
Off-board Assessment Analysis Ownership Cost Assumptions

"Ownership cost" provides a useful metric for comparing storage technologies on an equal footing, accounting for both on- and off-board (i.e., refueling) costs.

\begin{tabular}{|c|c|c|c|}
\hline $\begin{array}{l}\text { Simple Ownership } \\
\text { Cost (OC) Calculation: }\end{array}$ & \multicolumn{2}{|c|}{$\mathrm{OC}=\frac{\mathrm{C} \times \mathrm{DF} \times \text { Markup }}{\text { Annual Mileage }}+\frac{\mathrm{FC}}{\mathrm{FE}}$} & $\begin{array}{l}C=\text { Factory Cost of the On-board Storage System } \\
\text { DF = Discount Factor (e.g., } 15 \%) \\
\text { FC = Fuel Cost of the Off-board Refueling System } \\
\text { FE = Fuel Economy (e.g., } 62 \mathrm{mi} / \mathrm{kg})\end{array}$ \\
\hline $\begin{array}{l}\text { Ownership Cost } \\
\text { Assumptions }\end{array}$ & $\begin{array}{l}\text { Gasoline } \\
\text { ICEV }\end{array}$ & $\begin{array}{l}\text { Hydrogen } \\
\text { FCV }\end{array}$ & Basis/Comment \\
\hline $\begin{array}{l}\text { Annual Discount Factor } \\
\text { on Capital }\end{array}$ & $15 \%$ & $15 \%$ & Input assumption \\
\hline $\begin{array}{l}\text { Manufacturer + Dealer } \\
\text { Markup }\end{array}$ & 1.74 & 1.74 & Assumed mark-up from factory cost estimates ${ }^{1}$ \\
\hline Annual Mileage (mi/yr) & 12,000 & 12,000 & H2A Assumption \\
\hline $\begin{array}{l}\text { Vehicle Energy Efficiency } \\
\text { Ratio }\end{array}$ & 1.0 & 2.0 & $\begin{array}{l}\text { Based on ANL drive-cycle modeling for mid- } \\
\text { sized sedan }\end{array}$ \\
\hline Fuel Economy (mpgge) & 31 & 62 & $\begin{array}{l}\text { ICEV: Combined CAFE sales weighted FE } \\
\text { estimate for MY } 2007 \text { passenger } \text { cars }^{2}\end{array}$ \\
\hline $\begin{array}{l}\mathrm{H}_{2} \text { Storage Requirement } \\
\left(\mathrm{kg} \mathrm{H}_{2}\right)\end{array}$ & NA & 5.6 & $\begin{array}{l}\text { Design assumption based on ANL drive-cycle } \\
\text { modeling }\end{array}$ \\
\hline
\end{tabular}

${ }_{1}^{1}$ Source: DOE, "Effects of a Transition to a Hydrogen Economy on Employment in the United States", Report to Congress, July 2008

${ }^{2}$ Source: U.S. Department of Transportation, NHTSA, "Summary of Fuel Economy Performance," Washington, DC, March 2007

This ownership cost assessment implicitly assumes that each fuel system and vehicle has similar maintenance costs and operating lifetime.

( (IIAX)

Off-board Assessment Results Hydrogen Cost Comparison-Base Cases

The compressed system refueling costs are projected to be 1.5 to 2 times higher than the current DOE target range of $\$ 2-3 / \mathrm{kg}$.

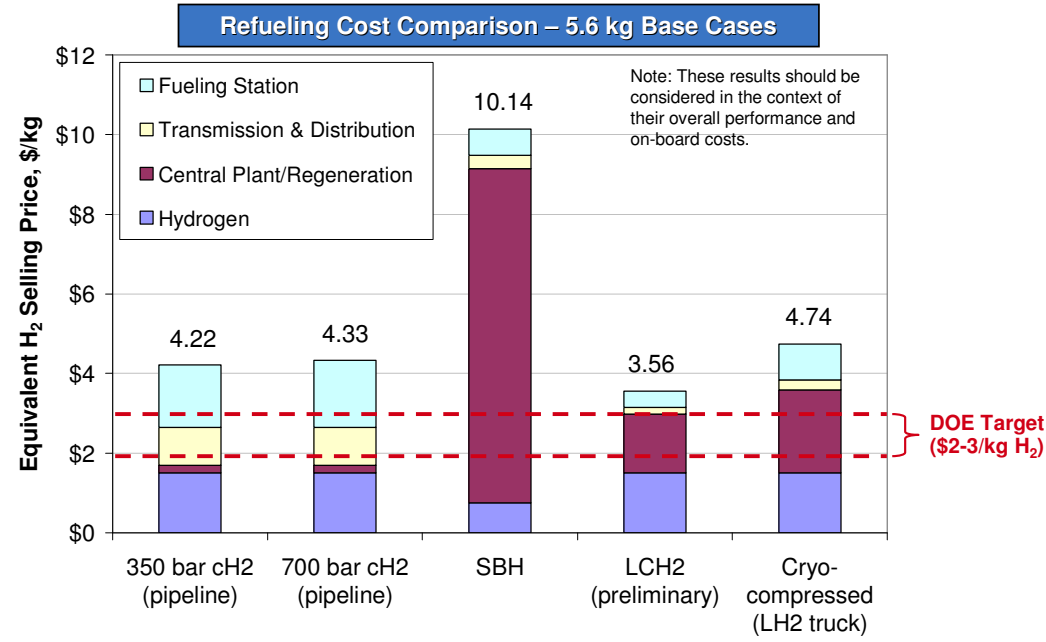

Note: 350-bar, 700-bar and cryo-compressed results were calculated using the base case delivery scenarios in HDSAM v2.06. SBH and $\mathrm{LCH}_{2}$ results were calculated using a modified H2A Delivery Components Carrier Model v34. All fuel costs exclude fuel taxes. 
Off-board Assessment Results Ownership Cost Comparison-Base Cases

Fuel system ownership cost for the base case compressed systems are projected to be $30-50 \%$ more expensive than gasoline at $\$ 3.00 /$ gal.

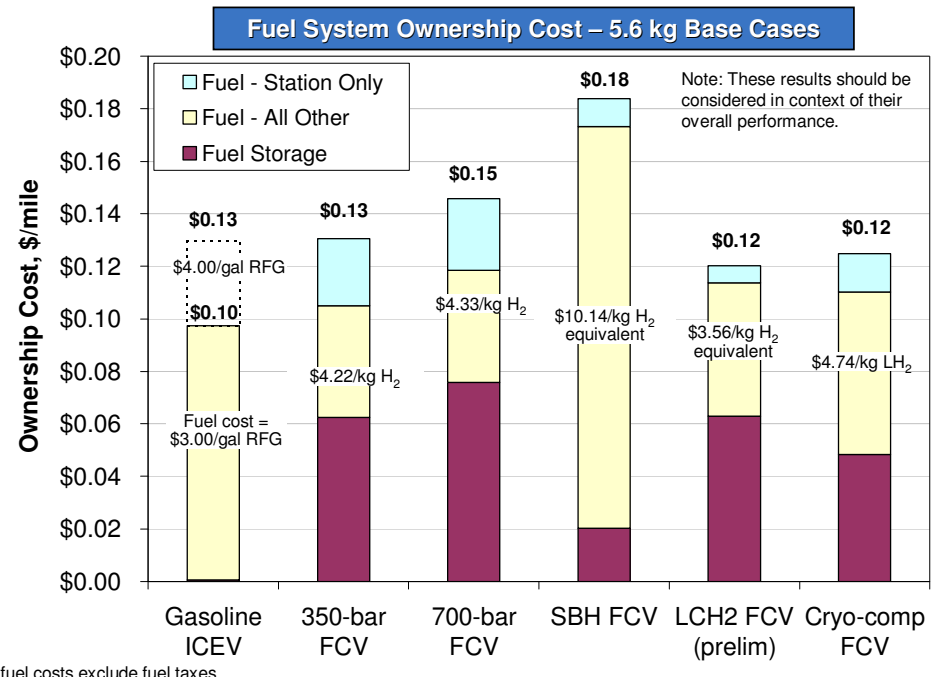

Note: All fuel costs exclude fuel taxes.

( (IITX)

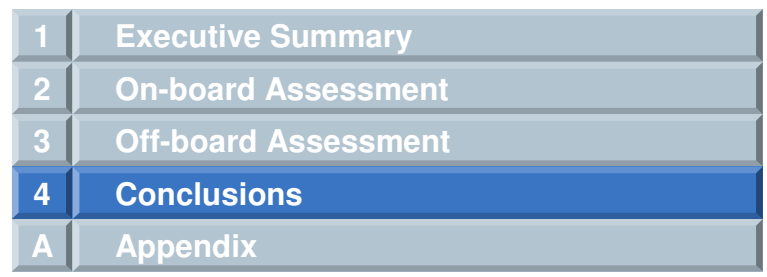


Executive Summary Conclusions

System costs are significantly higher than the current targets and do not have a clear path to achieve the DOE's long-term goals

- The high-volume manufactured cost projections of the on-board storage systems are 4-5 times the current DOE 2010 cost target

$>$ 350-bar and 700-bar Type IV systems are projected to cost $\$ 15 / \mathrm{kWh}$ and $\$ 19 / \mathrm{kWh}$

$>$ Type III tanks add $\$ 1.2 / \mathrm{kWh}$ (350-bar) to $\$ 2.2 / \mathrm{kWh}$ (700-bar) to the cost of Type IV tanks

$>$ Dual tank systems add $<\$ 0.5 / \mathrm{kWh}$ to the cost of hydrogen storage systems.

- Factory costs will likely range (95\% confidence) between $\$ 10.6$ and $\$ 19.7 / \mathrm{kWh}$ for the 350-bar system and between $\$ 13.5$ and $\$ 27.2 / \mathrm{kWh}$ for the 700 -bar system

- Refueling costs based on $\mathrm{H}_{2}$ pipeline delivery and high-pressure $\mathrm{H}_{2}$ dispensing, are projected to be 1.5-2 times more expensive than the DOE cost target of $\$ 2-3 / \mathrm{kg}$

- Compressed fuel system ownership costs will likely be about 30-50\% (3-5 c/mi or $\$ 250-600 / \mathrm{yr}$ ) higher than a conventional gasoline ICEV when gasoline is $\$ 3.00 / \mathrm{gal}$

$>$ 350-bar fuel system ownership costs would be comparable to gasoline at $\$ 4.00 / \mathrm{gal}$

$>$ 700-bar fuel system ownership costs would be comparable to gasoline at $\$ 4.50 / \mathrm{gal}$

When on-board and off-board costs are combined, the 350-bar compressed system has potential to have similar ownership costs as a gasoline ICEV.

(C) Note: All fuel costs exclude fuel taxes.

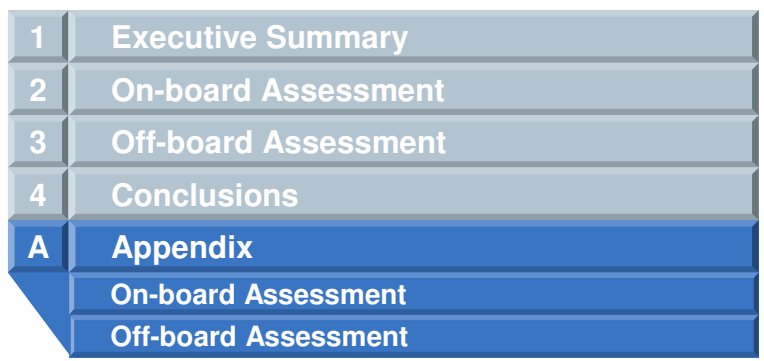


Appendix On-board Assessment Overview

The on-board cost and performance analyses are based on detailed technology assessment and bottom-up cost modeling.

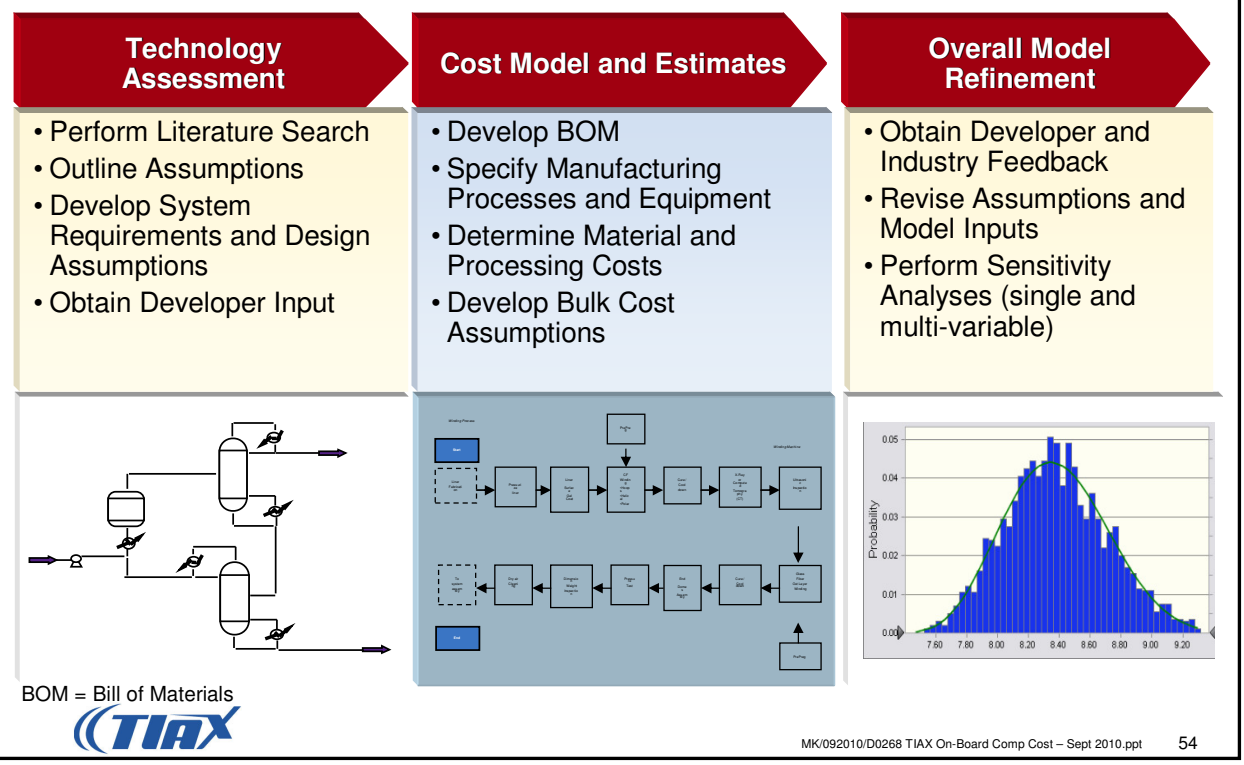

Appendix On-board Assessment Economic Assumptions

The cost of capital equipment, buildings, labor, and utilities are included in our processing cost assessments.

- Variable Cost Elements

$>$ Material

$>$ Direct Labor

$>$ Utility

- Operating Fixed Costs

$>$ Tooling \& Fixtures

$>$ Maintenance

$>$ Overhead Labor

$>$ Cost of Operating Capital

- Non-Operating Fixed Costs

$>$ Equipment

$>$ Building

$>$ Cost of Non-Operating Capital

Working Capital

$>$ Material, labor, utility, tooling and maintenance cost

$>$ Working capital period: 3 months

We assume $100 \%$ debt financed with an annual interest rate of $15 \%, 10$-year equipment life, and 25-year building life. 
Appendix On-board Assessment Factory Cost Definition

The cost model estimates the high volume factory cost of the onboard fuel system.

\begin{tabular}{|c|c|}
\hline Excluded from Cost Model & Profit \\
\hline $\begin{array}{l}\text { Corporate Expenses (example) } \\
\text { - Research and Development } \\
\text {. Sales and Marketing } \\
\text {. General \& Administration } \\
\text { - Warranty } \\
\text { - Taxes }\end{array}$ & $\begin{array}{c}\text { Sales } \\
\text { Expense } \\
\text { General } \\
\text { Expense }\end{array}$ \\
\hline Cost Model (Factory Cost) & Factory \\
\hline $\begin{array}{l}\text { Fixed Costs } \\
\text { : Equipment and Plant Depreciation } \\
: \text { Tooling Amortization } \\
: \text { Utiilities } \\
: \text { Indirect Maintenance } \\
\text {. Cost of capital } \\
\text { Variable Costs } \\
: \text { Manufactured Materials } \\
: \text { Purchased Materials } \\
: \text { Fabrication Labor } \\
\text { : Assembly Labor } \\
\text { Indirect Materials }\end{array}$ & $\begin{array}{c}\text { Direct } \\
\text { Materials }\end{array}$ \\
\hline
\end{tabular}

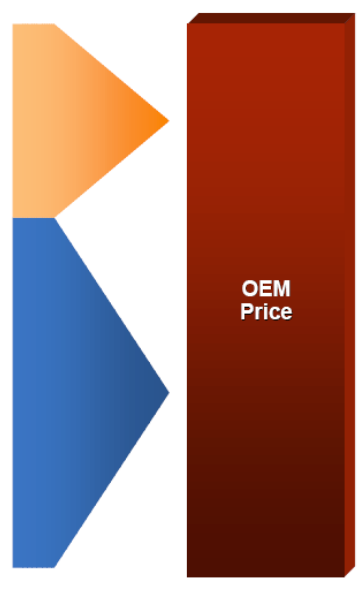

Profit, sales and general expenses are not included in the on-board system cost analysis, consistent with other TIAX cost analyses for DOE of, for example, PEMFC technology.

( (IIAX)

Appendix On-board Assessment Carbon Fiber Calculations

Tank end dome shape and carbon fiber thicknesses are based on ANL's latest performance analysis, which uses a composite pressure vessel algorithm.1,2

- Combination of geodesic and hoop windings assumed, with only geodesic windings on the end domes

- Non-uniform end dome thickness; thickest at dome peak (exit hole)

- Model yields carbon fiber weight calculations consistent with Quantum's models for compressed hydrogen (i.e., 350 and 700-bar) storage tanks

- Tank safety factor applied to the nominal tank pressure (i.e., 350 and 700 bar)

- Carbon fiber composite tensile strength assumed to be 2,550 MPa based on T700S Technical Data Sheet $\left(\right.$ Torayca $\left.^{\circledR} 2009\right)$.

$>$ Due to variance in carbon fiber quality, the average carbon fiber tensile strength was assumed to be $10 \%$ lower than the rated tensile strength. 
Appendix On-board Assessment Winding Time Assumptions

Fiber filament winding time is determined by the actual winding time plus setup time. Filament winding is an inherently slow process.

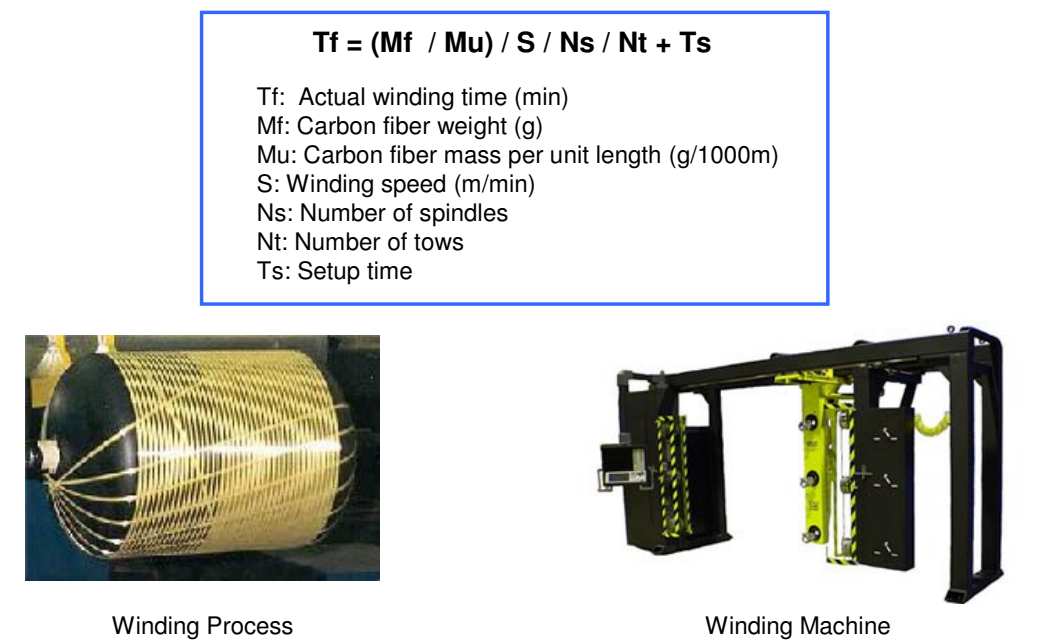

( (IIAX)

Appendix On-board Assessment Carbon Fiber Prepreg Approach

We assume the system manufacturer purchases pre-impregnated (i.e., "prepreg") carbon fiber composite as apposed to raw carbon fiber.

- We assume the system manufacturer purchases pre-impregnated (i.e., "prepreg") carbon fiber composite at a price that is 1.27 (prepreg/fiber ratio) times higher than the raw carbon fiber material (Du Vall 2001)

- An alternative approach would be to assume a wet resin winding process that would allow the purchase of raw carbon fiber material instead of buying prepreg tow fiber

- We selected the prepreg winding process based on the assumption that it results in greater product throughput and reduced environmental hazards (including VOCs, ODCs, and GHG emissions) compared to a wet winding process

> According to Du Vall (2001), greater throughput is typically achieved because prepreg tow allows for more precise control of resin content, yielding less variability in the cured part mechanical properties and ensuring a more consistent, repeatable, and controllable material compared to wet winding

$>$ In addition, wet winding delivery speeds are limited due to the time required to achieve good fiber/resin wet out

> The downside is that the prepreg raw material costs are higher than for wet winding

- It might be possible to reduce the overall manufactured cost of the composite, perhaps closer to the cost per pound of the carbon fiber itself $(\$ 13 / \mathrm{lb})$ or ever lower (since the resin is cheaper per pound), if the wet winding process is proven to be more effective

$>$ A detailed evaluation that is required to explore these cost trade-offs is beyond our scope of work

$>$ Instead, we address the potential for lower carbon fiber composite costs in the sensitivity analysis 
Appendix On-board Assessment Miscellaneous BOP Costs-Base Cases

We projected the cost of the miscellaneous BOP components using a combination of industry feedback, top-down and bottom-up estimates.

\begin{tabular}{|l|c|c|l|}
\hline $\begin{array}{c}\text { Purchased } \\
\text { Component Cost } \\
\text { Est. (\$ per unit) }\end{array}$ & $\begin{array}{c}\text { 350-bar } \\
\text { Base } \\
\text { Case }\end{array}$ & $\begin{array}{r}700 \text {-bar } \\
\text { Base Case }\end{array}$ & \multicolumn{1}{c|}{ Comments/Basis } \\
\hline Fittings and pipe & $\$ 7$ & $\$ 7$ & $\begin{array}{l}\text { Based on estimate of weight and SS304 raw material price } \\
\text { marked up for processing }\end{array}$ \\
\hline Check valve (2) & $\$ 14$ & $\$ 17.50$ & $\begin{array}{l}\text { Based on quotes from Bertram Controls for Circle Seal } \\
\text { check valve (2009) }\end{array}$ \\
\hline Manual valve (2) & $\$ 14$ & $\$ 17.50$ & Based on DFMA® software for a similar component \\
\hline Mounting bracket (2) & $\$ 6$ & $\$ 6$ & $\begin{array}{l}\text { Based on estimate of weight and standard steel raw } \\
\text { material price of } \$ 1 / k g\end{array}$ \\
\hline $\begin{array}{l}\text { Pressure relief } \\
\text { device (2) }\end{array}$ & $\$ 10$ & $\$ 12.50$ & $\begin{array}{l}\text { Based on similar component with markups for higher } \\
\text { pressure; thermally activated fuse metal device }\end{array}$ \\
\hline Temperature sensor & $\$ 5$ & $\$ 5$ & $\begin{array}{l}\text { Based on whole sale price estimate for gas temperature } \\
\text { probe }\end{array}$ \\
\hline Rupture disc & $\$ 2$ & $\$ 2$ & Based on discussions with developers and venders \\
\hline
\end{tabular}

Appendix On-board Assessment Processing Costs - Base Case and Sensitivity Parameters

We developed low and high estimates for key processing cost assumptions as input to the sensitivity analysis.

\begin{tabular}{|l|c|c|c|l|}
\hline $\begin{array}{c}\text { Processing Cost } \\
\text { Assumptions }\end{array}$ & Low & $\begin{array}{c}\text { Base } \\
\text { Cases }\end{array}$ & High & \multicolumn{1}{c|}{ Comments/Basis } \\
\hline $\begin{array}{l}\text { \# Tows in the CF } \\
\text { Winding }\end{array}$ & 6 & 12 & 24 & Discussions with tank developers (2007) \\
\hline $\begin{array}{l}\text { \# Tows in the GF } \\
\text { Winding }\end{array}$ & 12 & 16 & 14 & Discussions with tank developers (2007) \\
\hline $\begin{array}{l}\text { CF Filament } \\
\text { Winding Speed } \\
\text { (m/min) }\end{array}$ & 15 & 30 & 60 & Discussions with tank developers (2007) \\
\hline $\begin{array}{l}\text { GF Filament } \\
\text { Winding Speed } \\
\text { (m/min) }\end{array}$ & 15 & 30 & 60 & Discussions with tank developers (2007) \\
\hline $\begin{array}{l}\text { Filament Winding } \\
\text { Machine Cost } \\
\text { (\$1,000s) }\end{array}$ & 150 & 200 & 300 & Discussions with tank developers (2007) \\
\hline
\end{tabular}


Appendix On-board Assessment Processing Costs - Dual Tank Systems

The processing costs for dual tank systems are 15 to $20 \%$ higher than for single tank systems. This includes a $2 X$ increase in liner fabrication and glass winding costs.

\begin{tabular}{|l|c|c|}
\hline $\begin{array}{c}\text { Key Processing Steps - Compressed Gas } \\
\text { Tanks }\end{array}$ & $\begin{array}{c}\text { 350-bar Type IV } \\
\text { Dual Tank }\end{array}$ & $\begin{array}{c}\text { 700-bar Type IV Dual } \\
\text { Tank }\end{array}$ \\
\hline Liner Fabrication & $\$ 21$ & $\$ 21$ \\
\hline Carbon Fiber Winding Process & $\$ 90$ & $\$ 109$ \\
\hline Glass Fiber Winding Process & $\$ 12$ & $\$ 11$ \\
\hline Foam End Caps & $\$ 3$ & $\$ 2$ \\
\hline Assembly and Inspection & $\$ 37$ & $\$ 37$ \\
\hline Total & $\$ 162$ & $\$ 180$ \\
\hline
\end{tabular}

For reference, the processing costs of 350-bar and 700-bar single tank systems are $\$ 138$ and $\$ 156$, respectively

Appendix On-board Assessment Processing Costs - Type III Systems

The processing costs for Type III systems are 2 to $6 \%$ higher than Type IV systems. This includes a large increase in liner fabrication cost and a small decrease in the carbon fiber winding cost

\begin{tabular}{|l|c|c|}
\hline Key Processing Steps - Compressed Gas & $\begin{array}{c}\text { 350-bar Type III } \\
\text { Sanks }\end{array}$ & $\begin{array}{c}\text { 700-bar Type III } \\
\text { Single Tank }\end{array}$ \\
\hline Liner Fabrication & $\$ 23$ & $\$ 25$ \\
\hline Carbon Fiber Winding Process & $\$ 74$ & $\$ 96$ \\
\hline Glass Fiber Winding Process & $\$ 7$ & $\$ 6$ \\
\hline Foam End Caps & $\$ 2$ & $\$ 1$ \\
\hline Assembly and Inspection & $\$ 36$ & $\$ 36$ \\
\hline Total & $\$ 141$ & $\$ 165$ \\
\hline
\end{tabular}

For reference, the processing costs of 350-bar and 700-bar single tank systems are $\$ 138$ and $\$ 156$, respectively 
Appendix On-board Assessment Cost Updates-Base Cases

Since the initial 2004 assessment, we have continually updated our compressed system models based on new information from developers and industry.

- Key 2006 Adjustments

> Carbon fiber translation efficiencies of $81.5 \%$ for 350 -bar and $63 \%$ for 700 -bar tanks were used based on published information from Quantum ${ }^{1}$

$>$ Safety factor changed from 2.25 to 2.35 based on industry feedback

- Key 2008 Updates

> Safety factor applied to max filling over pressure (i.e., 438 and 875 bar) rather than nominal tank pressure (i.e., 350 and 700 bar) based on industry feedback

> Raw carbon fiber material cost updated from $\$ 10 / \mathrm{lb}$ to $\$ 13 / \mathrm{lb}$ for fiber based on feedback from manufacturer (30\% increase)

$>$ Safety factor changed from 2.35 back to 2.25 based on new industry feedback

> 350-bar translation efficiency adjusted to $82.5 \%$ based on ANL assumption

- Key 2009 Updates

$>$ Safety factor applied to nominal tank pressure (i.e., 350 and 700 bar) rather than max filling over pressure (i.e., 438 and 875 bar) based on new industry feedback

> Carbon fiber composite tensile strength decreased from 2,940 MPa to 2,550 MPa based on ANL assumption

$>$ Tank end dome shape and carbon fiber thicknesses were modified based on ANL's latest performance analysis

$>$ Other less significant changes were made based on industry feedback or to match ANL assumptions

$>$ BOP costs reduced based on industry feedback

(C) ${ }^{1}$ Previously assumed 100\% translation efficiency due to lack of published information. MK/092010:D0268 TIAX On-Board Comp Cost - Sept 2010.ppt

Appendix On-board Assessment Cost Updates - Base Cases

Compressed system models updates (Cont'd)

- Key 2010 Adjustments

> Type III (Aluminum lined tank) and two-tank system designs were evaluated based on ANL's performance assessment

> The average carbon fiber composite strength was reduced by $10 \%$ to account for variability in carbon fiber quality based on DOE discussions with industry

> Translation strength factor was increased for the 700 bar tank from $63 \%$ to $80 \%$ based on ANL discussions with Quantum

> Additional manual service vent valve, check valve, pressure release device, and rupture disks, and solenoid shutoff valves were added to the balance of plant 
Appendix On-board Assessment Comparison to Previous BOP Costs-Base Cases

Cost projections for the BOP components were reduced significantly in 20092010 based on industry feedback and additional analysis.

\begin{tabular}{|l|c|c|c|c|c|c|}
\hline \multirow{2}{*}{$\begin{array}{c}\text { Purchased Component } \\
\text { Cost Est. (\$ per unit) }\end{array}$} & \multicolumn{3}{|c|}{ 350-bar Base Cases } & \multicolumn{3}{c|}{ 700-bar Base Cases } \\
\cline { 2 - 7 } & 2010 & $\mathbf{2 0 0 8}$ AMR & $\%$ Change & 2010 & 2008 AMR & $\%$ Change \\
\hline Pressure regulator & $\$ 160$ & $\$ 250$ & $-36 \%$ & $\$ 200$ & $\$ 350$ & $-43 \%$ \\
\hline Solenoid Control valve (3) & $\$ 186$ & $\$ 40$ & $365 \%$ & $\$ 232.5$ & $\$ 50$ & $365 \%$ \\
\hline Fill tube/port & $\$ 50$ & $\$ 80$ & $-38 \%$ & $\$ 62.5$ & $\$ 100$ & $-38 \%$ \\
\hline Pressure transducer & $\$ 30$ & $\$ 20$ & $50 \%$ & $\$ 37.5$ & $\$ 30$ & $25 \%$ \\
\hline Pressure gauge & $\$ 17$ & NA & $100 \%$ & $\$ 17$ & NA & $100 \%$ \\
\hline Boss and plug (in tank) & $\$ 15$ & $\$ 100$ & $-85 \%$ & $\$ 19$ & $\$ 120$ & $-84 \%$ \\
\hline Fittings and pipe & $\$ 7$ & $\$ 30$ & $-77 \%$ & $\$ 7$ & $\$ 40$ & $-83 \%$ \\
\hline Check valve (2)* & $\$ 14$ & $\$ 40$ & $-65 \%$ & $\$ 17.50$ & $\$ 50$ & $-65 \%$ \\
\hline Manual valve (2) & $\$ 14$ & $\$ 40$ & $-65 \%$ & $\$ 17.50$ & $\$ 50$ & $-65 \%$ \\
\hline Mounting bracket & $\$ 6$ & $\$ 10$ & $-40 \%$ & $\$ 6$ & $\$ 10$ & $-40 \%$ \\
\hline Pressure relief device (2) & $\$ 10$ & $\$ 40$ & $-75 \%$ & $\$ 12.50$ & $\$ 50$ & $-75 \%$ \\
\hline Temperature sensor & $\$ 5$ & $\$ 20$ & $-75 \%$ & $\$ 5$ & $\$ 20$ & $-75 \%$ \\
\hline Rupture disc (2)* & $\$ 2$ & $\$ 40$ & $-95 \%$ & $\$ 2$ & $\$ 50$ & $-96 \%$ \\
\hline Total BOP & $\$ 516$ & $\$ 710$ & $-27 \%$ & $\$ 636$ & $\$ 910$ & $-30 \%$ \\
\hline
\end{tabular}

Additional quantities of several components were included in the revised cost estimates (marked with a *)

(IITX

Appendix On-board Assessment Cost Comparison to Industry

Our system cost estimates, adjusted for progress ratios of 85 to $90 \%$, are consistent with industry factory cost projections for similar tanks at lower production volumes.

- Industry factory cost projections for low volume manufacturing (i.e., 1,000 units per year) range from $\$ 45-55 / \mathrm{kWh}$ for 350-bar tank systems and \$55-65/kWh for 700-bar tank systems

$>$ Excludes valves and regulators

$>$ Industry projections are for 100-120 liter water capacity tanks versus 149-258 liter water capacity tank designs evaluated by TIAX

- Removing valve and regulator costs from the TIAX base case cost projections results in a high-volume $(500,000$ units per year) factory cost of $\$ 13 / \mathrm{kWh}$ and $\$ 16 / \mathrm{kWh}$ for 350 -bar and 700-bar tank systems, respectively

- These results compare well to the low volume industry projections assuming progress ratios of $85-90 \%$

$>$ The progress ratio (pr) is defined by speed of learning (e.g., how much costs decline for every doubling of capacity)

$>$ While $85-90 \%$ progress ratio is typically on the high end of what would be expected (progress ratios of $70-90 \%$ are typical), this is likely due to carbon fiber representing such a large fraction of the overall system cost

$>$ Unlike other system components, carbon fiber is already produced at very high-volumes for the aerospace industry, so it isn't expected to become significantly cheaper due to the typical learning curves assumed by a projection based on progress ratios ${ }^{1}$

${ }^{1}$ However, there are DOE programs that are looking at ways to significantly reduce carbon fiber costs (e.g., Abdallah 2004). 


\begin{tabular}{|c|c|c|c|}
\hline Off-board Asses & Owr & Cost Inc & ng Vehicle Cost Assumptions \\
\hline \multicolumn{4}{|c|}{$\begin{array}{l}\text { In addition to fuel system ownership cost, we can also look at the overall } \\
\text { vehicle ownership cost, where the vehicle purchased cost is included. }\end{array}$} \\
\hline Vehicle Cost Assumptions ${ }^{1}$ & $\begin{array}{l}\text { Gasoline } \\
\text { ICEV }\end{array}$ & $\begin{array}{l}\text { Hydrogen } \\
\text { FCV }\end{array}$ & Basis/Comment \\
\hline Glider & $\$ 7,148$ & $\$ 7,148$ & $\begin{array}{l}\text { Group of components (e.g., body, chassis, suspension) } \\
\text { that will not undergo radical change }\end{array}$ \\
\hline IC Engine/Fuel Cell Subsystem & $\$ 2,107$ & $\$ 2,549$ & Includes engine cooling radiator \\
\hline $\begin{array}{l}\text { Transmission, Traction Motor, } \\
\text { Power Electronics }\end{array}$ & $\$ 1,085$ & $\$ 1,264$ & Includes electronics cooling radiator \\
\hline Exhaust, Accessories & $\$ 500$ & $\$ 500$ & Assumes exhaust and accessories are $\$ 250$ each \\
\hline Energy Storage & $\$ 110$ & $\$ 1,755$ & $\begin{array}{l}\text { Includes battery hardware, acc battery and energy } \\
\text { storage cooling radiator }\end{array}$ \\
\hline Fuel Storage & $\$ 51$ & $\$ 4,997^{\text {a }}$ & $\mathrm{H}_{2}$ storage cost from On-board Cost Assessment \\
\hline $\begin{array}{l}\text { Manufacturing/ Assembly } \\
\text { Markup }\end{array}$ & $\$ 5,500$ & $\$ 7,045$ & \multirow{2}{*}{$\begin{array}{l}\text { OEM manufacturing cost is marked up by a factor of } 1.5 \\
\text { and a dealer mark-up of } 1.16\end{array}$} \\
\hline Dealer Markup & $\$ 2,690$ & $\$ 3,445$ & \\
\hline Total Retail Price & $\$ 19,191$ & $\$ 28,034$ & \\
\hline
\end{tabular}

a Fuel Storage cost for the Hydrogen FCV option assumes 350 bar compressed hydrogen on-board storage system at $\$ 15.4 / \mathrm{kWh}$

Source: DOE, "Effects of a Transition to a Hydrogen Economy on Employment in the United States", Report to Congress, July 2008. All costs, except for the FCV Fuel Storage costs, are based on estimates for the Mid-sized Passenger Car case. See report for details.

Vehicle cost estimates assume that all FCV components, except the fuel storage system, meet DOE's cost goals for 2015 and beyond. ${ }^{1}$

\section{( (IIAX}

Appendix Off-board Assessment Ownership Cost Including Vehicle Cost-Base Cases

When the whole vehicle is included, and using an O\&M cost of $\$ 0.043 / \mathrm{gge}$ for all cases, the compressed FCV ownership cost is projected to be 10 to $15 \%$ higher than a conventional gasoline ICEV when gasoline is $\$ 3 / \mathrm{gal}$.

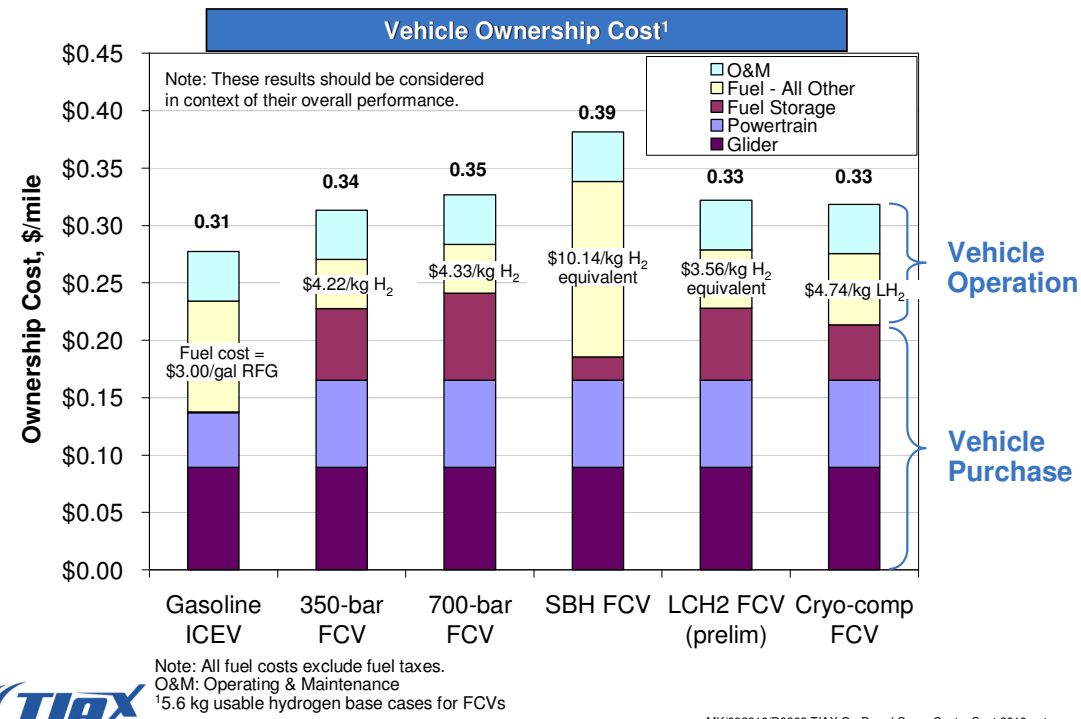




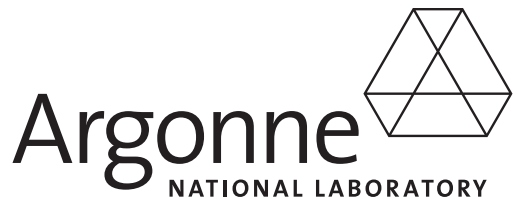

Nuclear Engineering Division

Argonne National Laboratory

9700 South Cass Avenue, BIdg. 208

Argonne, IL 60439-4842

www.anl.gov 